Andrews University

Digital Commons @ Andrews University

2010

\title{
A Strategy for Effective Youth Ministry in the Bantama Seventh- day Adventist Church Ghana
}

Kofi Opoku Acheampong

Andrews University

Follow this and additional works at: https://digitalcommons.andrews.edu/dmin

Part of the Practical Theology Commons

\section{Recommended Citation}

Acheampong, Kofi Opoku, "A Strategy for Effective Youth Ministry in the Bantama Seventh-day Adventist Church Ghana" (2010). Professional Dissertations DMin. 634.

https://dx.doi.org/10.32597/dmin/634

https://digitalcommons.andrews.edu/dmin/634

This Project Report is brought to you for free and open access by the Graduate Research at Digital Commons @ Andrews University. It has been accepted for inclusion in Professional Dissertations DMin by an authorized administrator of Digital Commons @ Andrews University. For more information, please contact repository@andrews.edu. 


\begin{abstract}
A STRATEGY FOR EFFECTIVE YOUTH MINISTRY IN THE BANTAMA SEVENTH-DAY ADVENTIST CHURCH GHANA
\end{abstract}

\title{
by
}

Kofi Opoku Acheampong

Adviser: Baraka G. Muganda 


\section{ABSTRACT OF GRADUATE STUDENT RESEARCH \\ Dissertation}

Andrews University

Seventh-day Adventist Theological Seminary

\section{Title: A STRATEGY FOR EFFECTIVE YOUTH MINISTRY IN THE BANTAMA SEVENTH-DAY ADVENTIST CHURCH, GHANA}

Name of Researcher: Kofi Opoku Acheampong

Name and degree of faculty advisor: Baraka G. Muganda, EdD

Date completed: February 2010

\section{Problem}

Young people comprise two-thirds of the 1,500 members of the Bantama

Seventh-day Adventist Church in Ghana. Despite a continuing increase in the number of young people, only a few of them attend youth activities. It appears that there may be a lack of formal programming or clear directions for youth ministry in the church. The result is a lack of spiritual connections between the youth and the church. In addition, there are behavioral problems among the young people when they are left to their own activities; consequently, parents are not allowing their children to attend youth-initiated activities, resulting in friction in the homes. 


\section{Method}

This is a qualitative descriptive study. An inductive approach was followed: observations and informal interviews revealed areas of concern. The researchers own experience also contributed to the exploration of contributing factors. Previously published literature on the topic of youth ministry and a study of Scripture formed the basis of establishing a biblical foundation for working with youth within the context of the church in Bantama, Ghana. Identifying definitions, such as the use of the term youth, were examined in both the Old and New Testaments.

\section{Results}

Some problems deterring youth from involvement and participation were discovered, and an incarnational model demonstrated by Jesus was offered for a possible solution. The principles of an incarnational ministry model were made clearer for youth pastors, parents, and church leaders in order to provide an effective youth ministry based on Scripture. Throughout the Scriptures, there are examples of how God used young people for ministry. As a result of this study, training programs based on biblical principles have been developed to train church leaders, pastors, parents, and adults. A better understanding of how cultural practices might be in conflict with these principles and how a change of cultural mentalities was needed led to better relationships between youth and adult members of the church. The restructuring of youth ministry in the Bantama Church has established greater enthusiasm on the part of the youth towards involvement and participation. 


\section{Conclusion}

Whenever young people attend a church and are in search of a spirit-filled experience, the incarnational ministry is one of the most viable options for adults to consider. This is a paradigm shift from adult leadership to the calling, training, and empowering of youth that involves them in the leadership roles. The spirit of teamwork work among adults and youth creates a harmonious approach to ministry. The Bantama Church has experienced this paradigm shift. There is greater adult support for the youth, which gives focus to the youth ministry. 
Andrews University

Seventh-day Adventist Theological Seminary

A STRATEGY FOR EFFECTIVE YOUTH MINISTRY IN THE

BANTAMA SEVENTH-DAY ADVENTIST CHURCH

GHANA

\author{
A Dissertation \\ Presented in Partial Fulfillment \\ of the Requirements for the Degree \\ Doctor of Ministry
}

by

Kofi Opoku Acheampong

February 2010 
(C) Copyright by Kofi Opoku Acheampong 2010 All Rights Reserved 
A STRATEGY FOR EFFECTIVE YOUTH MINISTRY IN THE BANTAMA SEVENTH-DAY ADVENTIST CHURCH - GHANA -

A dissertation

presented in partial fulfillment

of the requirements for the degree

Doctor of Ministry

by

Kofi Opoku Acheampong

APPROVAL BY THE COMMITTEE:
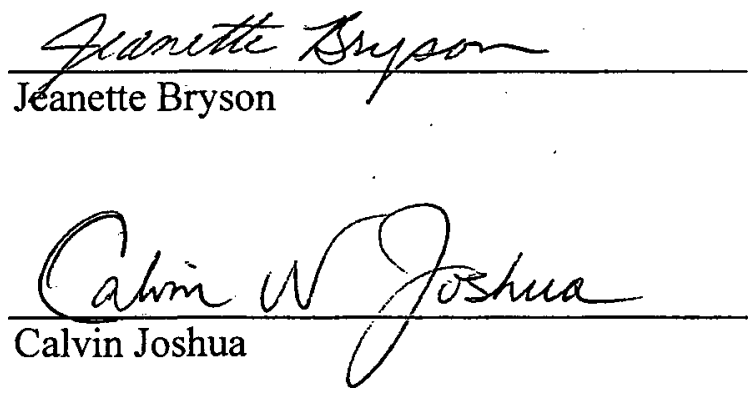

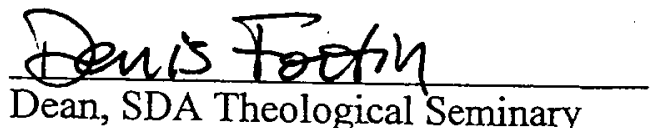

Dean, SDA Theological Seminary Denis Fortin

6 December 2012

Date approved 
Dedicated to my spouse Agnes Opoku Acheampong, son Japhet, daughter Elsie, and Pastor and Mrs. Anthony Yeboah Amoako 


\section{TABLE OF CONTENTS}

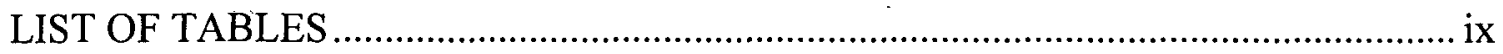

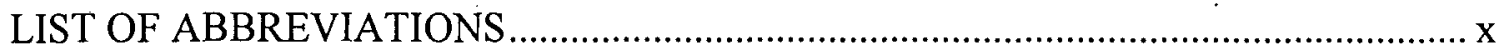

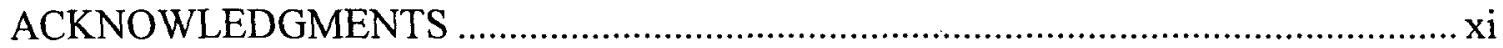

Chapter

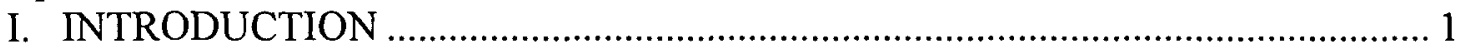

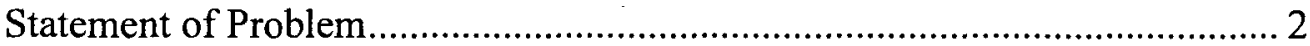

Justification of the Project ....................................................................... 3

Description of the Project Process .................................................................. 4

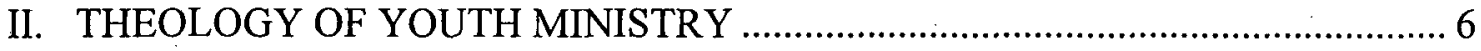

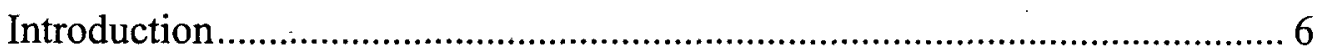

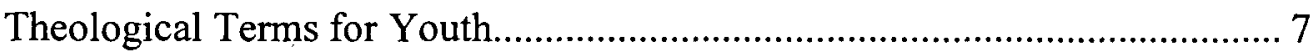

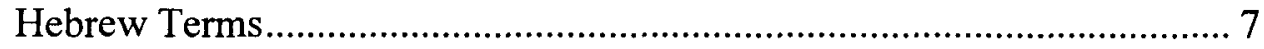

$\mathrm{Na}^{\prime} \mathrm{ar}$

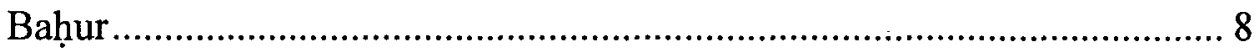

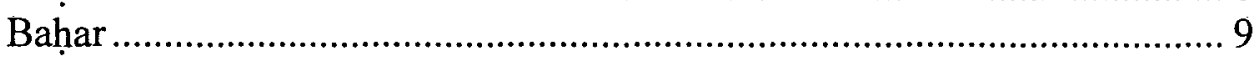

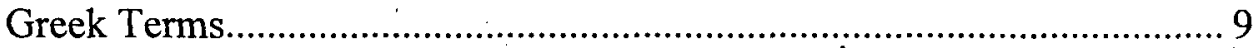

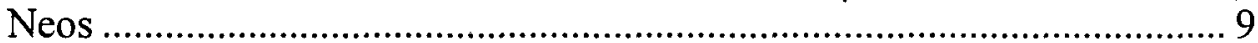

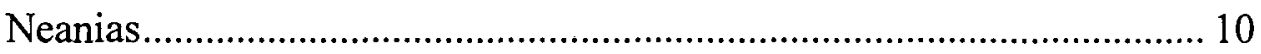

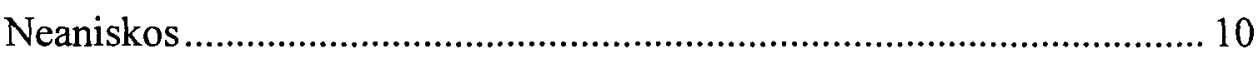

Youth called as Kings and Queens ...................................................... 11

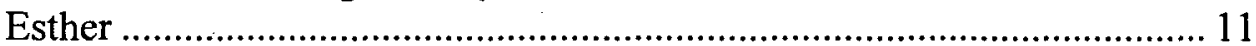

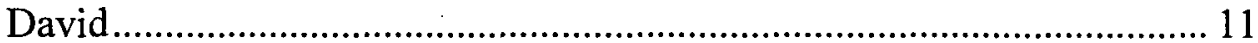

Youth Called as Prophets.................................................................... 12

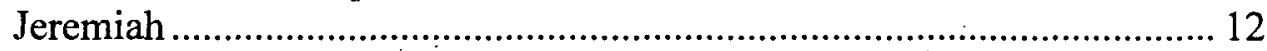

Youth Called as Priests ...................................................................... 13

The Importance of Youth ......................................................................... 14

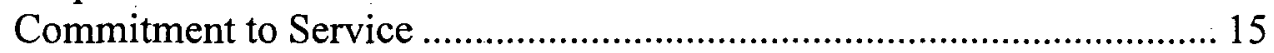

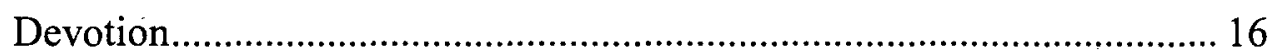

Theological Reflection of Ministry ........................................................... 17

Importance of Ministry Goals ............................................................. 19

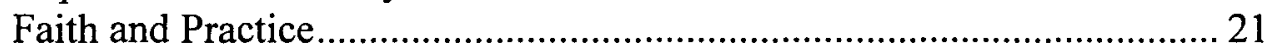

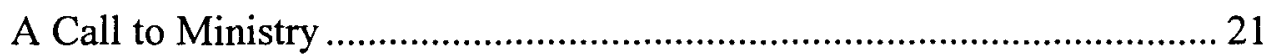


Summary

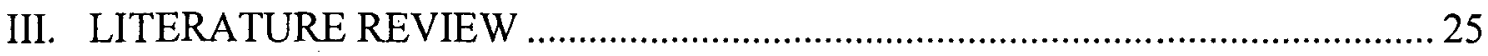

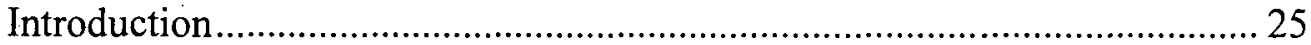

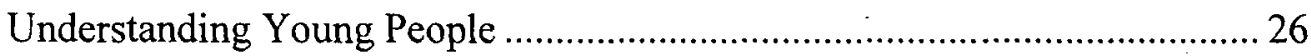

Changing Times with Young People ...................................................... 29

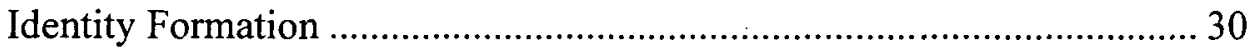

Young People and Modern Technology ……………….......................... 31

Underlying Impact ..................................................................................... 32

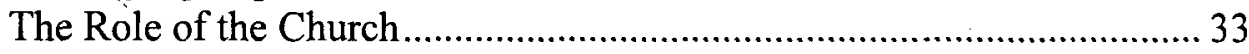

Deeper Relationship ................................................................................ 35

Youth Ministry in a Multiethnic/Multicultural Context ................................. 37

Cultural Practices and Beliefs.................................................................. 38

Cultural Influence on Parental Relationships ........................................... 41

Major Behavioral Problems and Confrontation ............................................. 43

Youth Leadership Issues ...................................................................... 45

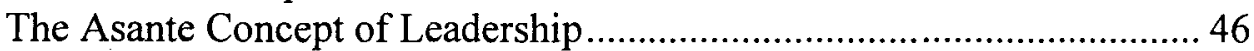

Power and Authority in Leadership ...................................................... 48

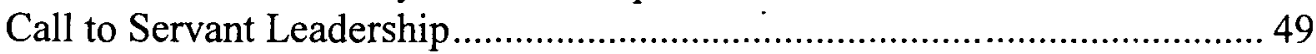

Jesus' Example of Leadership .............................................................. 49

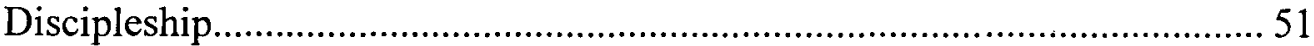

Training Youth as Disciples................................................................. 52

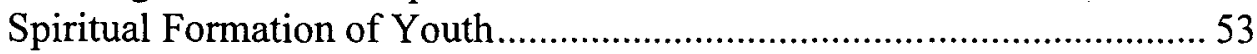

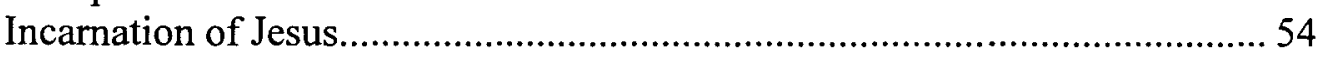

Incarnational Model of Youth Mnistry .......................................................... 55

Organizing for Growth through the Incarnational Model..........................5 57

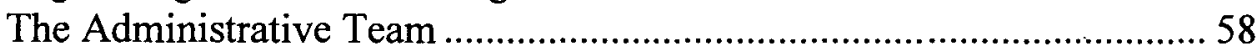

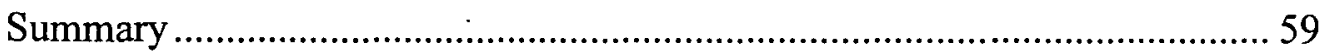

IV. INCARNATIONAL MODEL OF YOUTH MINISTRY FOR THE BANTAMA

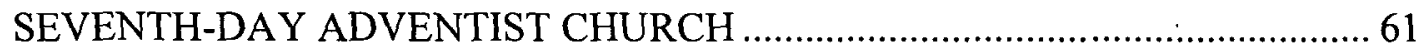

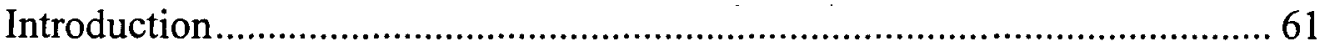

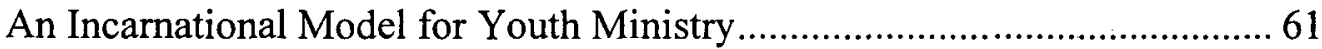

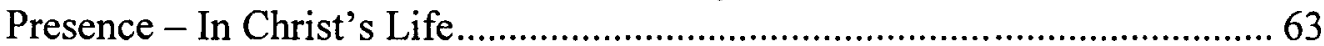

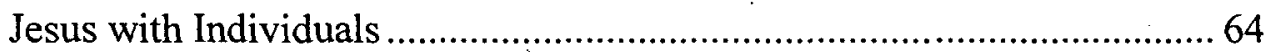

Jesus among Religious Groups ............................................................... 66

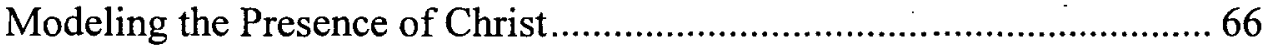

The Church's Understanding of Youth Ministry ............................................. 67

Involving Youth in Service for God ..........................................................69

Empowering the Young People ............................................................... 71

The Influence of Youth Ministry on Church Growth .............................. 72

Christ's Example of Servant Leadership ....................................................... 74

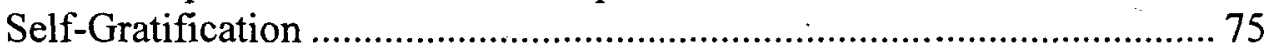

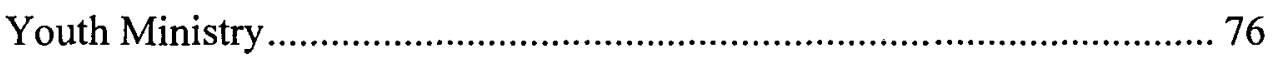




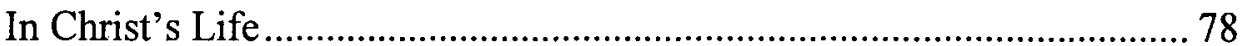

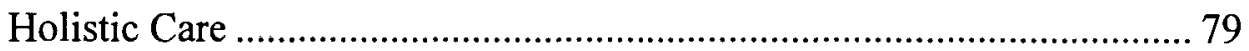

Experiencing Discipleship .................................................................. 79

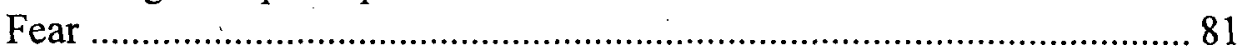

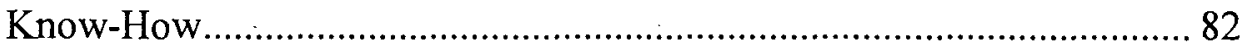

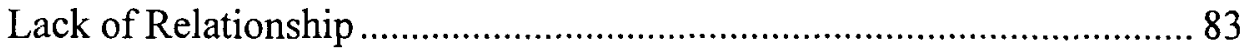

Youth Ministry through the Gifts of the Holy Spirit ............................... 85

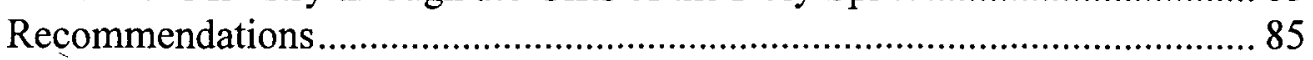

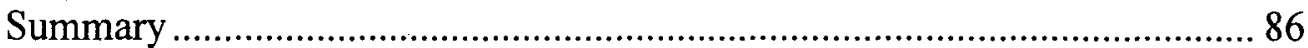

\section{DEVELOPING CONTEMPORARY STRATEGIES FOR YOUTH MINISTRY}

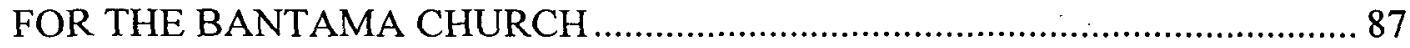

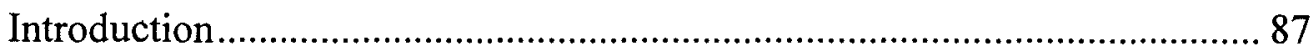

History of Bantama Seventh-day Adventist Church..................................... 88

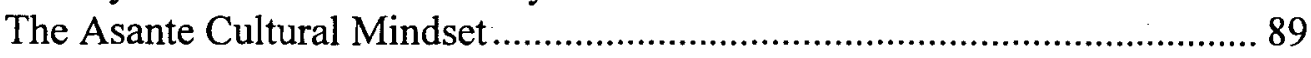

The Meaning of Nkwadaa in the Asante Culture..................................... 89

Broken Relationships between Adults and Youth .................................... 89

Changing the Cultural Mindset of Adults....................................................... 90

Jesus' Model of Leadership through Incarnational Ministry ..................... 91

Characteristics of Unhealthy Leadership ................................................. 92

Developing Parents' Relationship Skills with Youth .................................... 93

Improving Young People and their Parents' Relationship ............................. 94

Obedient to Parents .................................................................................. 94

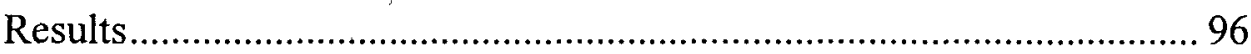

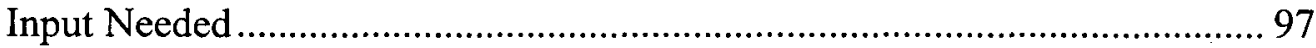

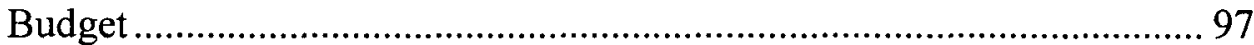

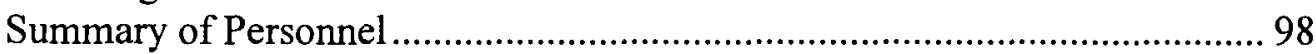

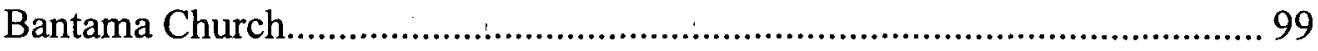

Process of Organization ........................................................................ 99

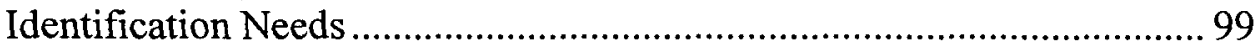

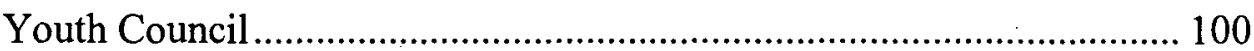

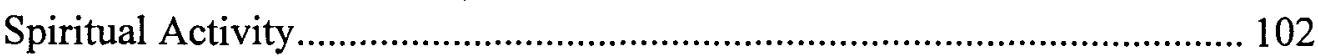

Alone with God - Home Devotion ..................................................... 102

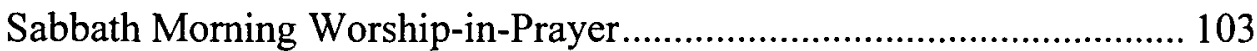

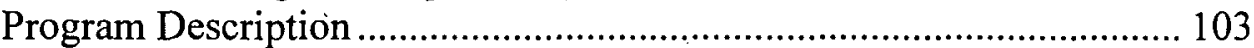

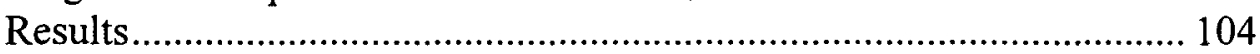

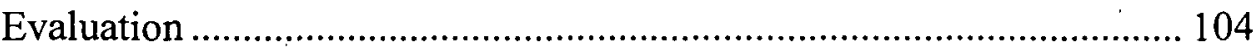

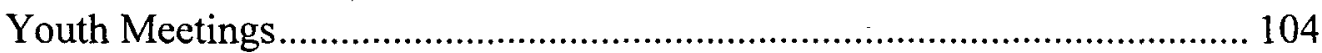

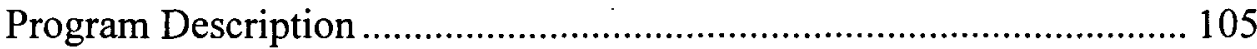

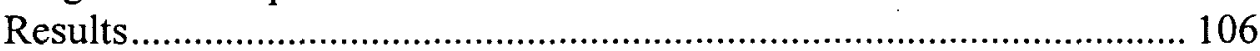

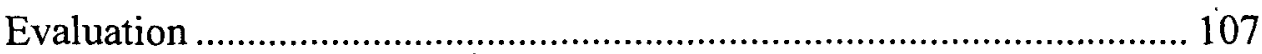

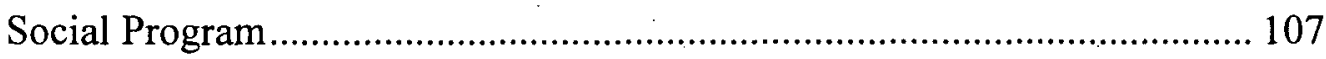

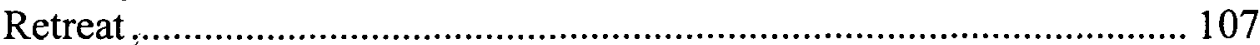

Program Description ....................................................................... 108

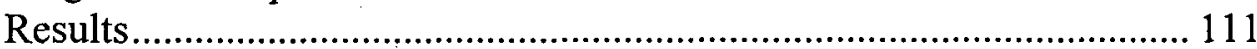


Evaluation 111

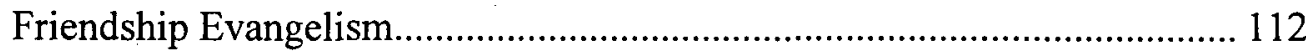

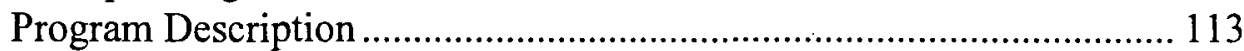

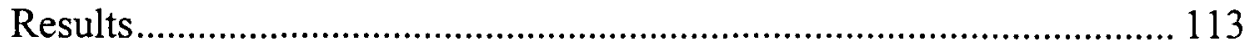

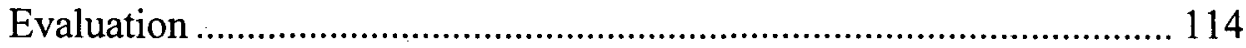

Week of Spiritual Emphasis....................................................................... 114

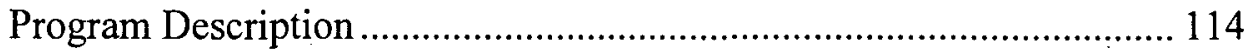

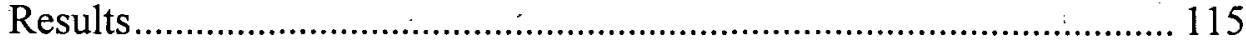

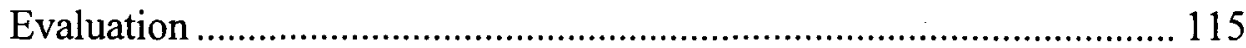

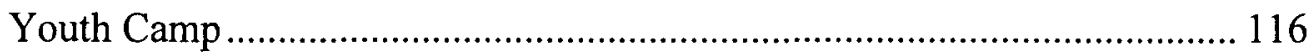

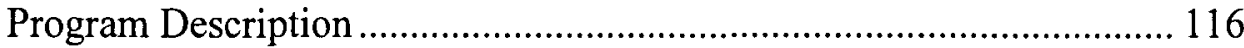

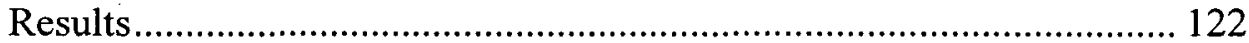

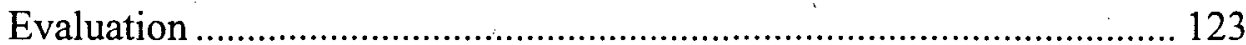

Youth Investiture Service ......................................................................... 123

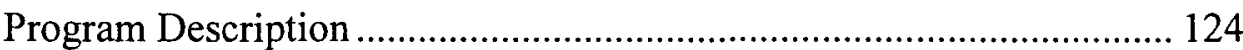

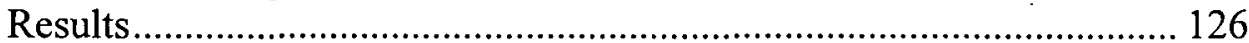

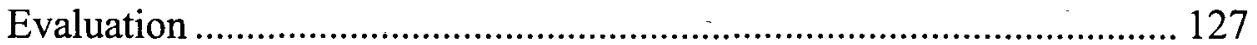

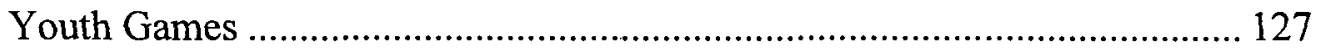

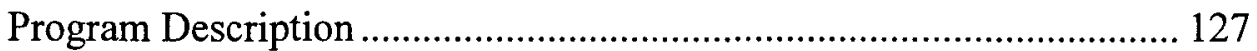

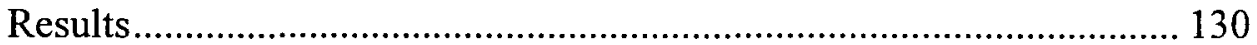

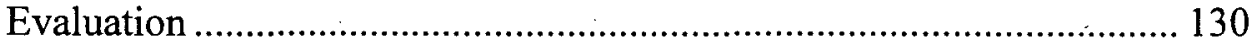

Family-Based Youth Ministry ……………………............................. 130

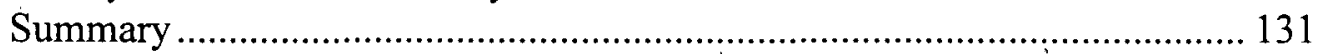

VI. REPORT, SUMMARY, CONCLUSION, AND RECOMMENDATIONS ......... 133

A Brief Project Report ........................................................................... 133

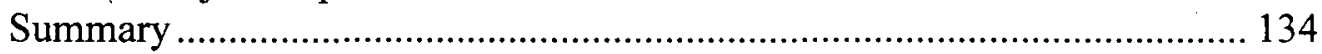

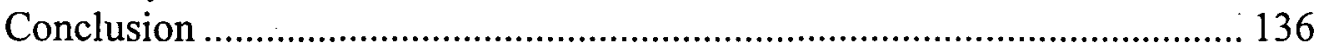

Application of Incarnational Model..................................................... 138

Challenges Facing the Bantama Church .............................................. 141

Recommended Youth Ministry Model ................................................. 142

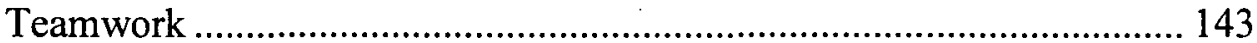

Develop Statement of Purpose............................................................ 144

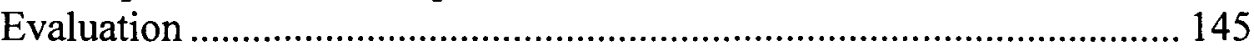

Appendix

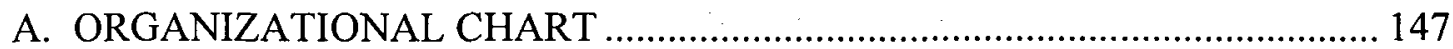

B. YOUTH COUNCIL EXECUTIVE BOARD ………..................................... 149

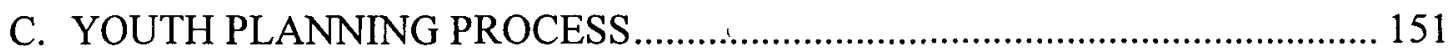

D. INTERVIEWS WITH BANTAMA CHURCH PASTOR, .............................. 153 


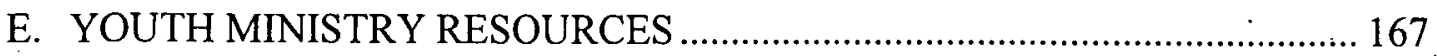

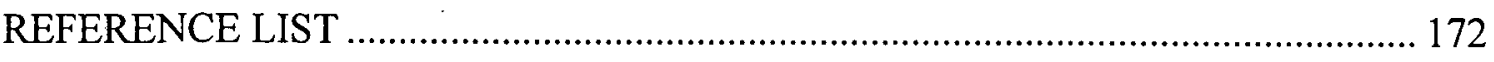

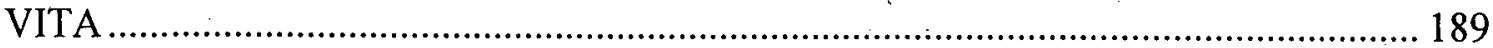




\section{LIST OF TABLES}

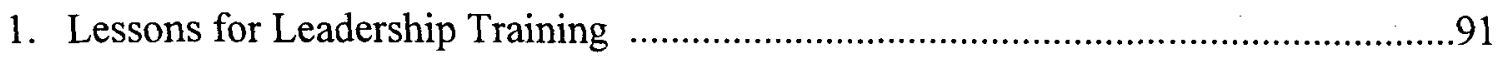

2. Lessons about Obedience for the Young People ......................................................95

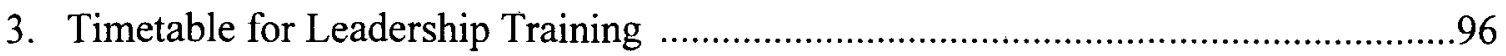

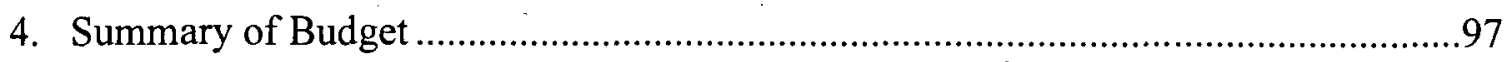

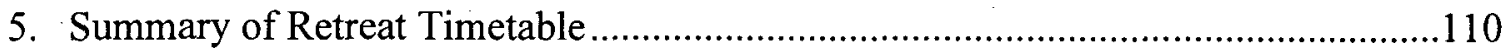

6. Budget Committee Proposed Budget....................................................................120

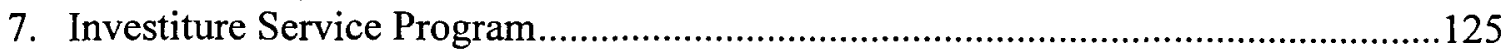




\section{LIST OF ABBREVIATIONS}

C

CGC OF SDA Central Ghana Conference of Seventh-day Adventists

BSSS

CGC
Ghana Currency

Bantama Senior Secondary School

Central Ghana Conference 


\section{ACKNOWLEDGMENTS}

I sincerely give glory and honor to God who has led me throughout this journey towards the dissertation. My appreciation goes to the Central Ghana Conference of SDA, Andrews University Theological Seminary and the International Student's office, who . enabled me to meet part of my doctoral expenses. I also express my profound gratitude to my spouse Agnes Opoku Acheampong alias Obaahema Ataa Birago Kotoko, and Japhet and Elsie my children for their generous sacrifice of financial and moral support. I am proud of you.

Also, I would like to express my deepest appreciation to my dissertation committee members, Dr. Baraka G. Muganda and Dr. Jeannette Bryson whose immeasurable supervisions have led me this far. Their different areas of expertise contributed greatly to the dissertation.

Thanks also to Dr. Daniel Opoku Boateng, a lecturer of Valley View University, Accra, Ghana who rightly set the foundation for the academic journey. Then to all my fellow past and present Ghanaian Seminary students, Michiana Ghanaian SDA church, I say, thank you so much. 


\section{CHAPTER 1}

\section{INTRODUCTION}

The Bantama Seventh-day Adventist Church in Kumase, Ghana, is one of the main churches in the Central Ghana Conference of Seventh-day Adventists (CGC). The church has the largest membership, and its financial contribution continues substantially to sustain the Conference. After entering the ministry as a literature evangelist in 1977 , I served as a pastor, district pastor, and associate pastor in various districts in the CGC, stopping to attend Valley View University and Andrews University. In 2000, the Conference asked me to serve as the pastor for the Bantama District with specific instructions to help improve the youth ministry in the Bantama Church. It is in working with the youth that the need for developing a strategy for youth ministry that would serve as a model became my passion.

As the new district pastor, I read through the records and found that about one third of the membership was made up of young people. After my first quarter in the church, I realized that the young people had no part in planning and implementing ideas in the church. The lack of their involvement in church activities was not limited to the church only, but also in their homes. I observed that there were some cultural beliefs and values that had created a gap between the youth and their parents, and which had become a normal practice in the church.

Furthermore, youth meetings were creating a lot of problems to the church and the 
surrounding communities. There was no adult, parent, or church leader to attend the youth meetings. Due to lack of directions in their programming, the youth were involved in all kinds of undesirable behaviors. Parents and church leaders had a difficult time trying to contain them because of the lack of a positive relationship. The youth were assigned to certain programs, like performing in burial ceremonies that brought fame to the church. Most of them, though, attended church on Sabbaths, but they were merely present, not involved in participation, in programming, or in the church leadership. The youth were spectators and fun-makers, especially in the external programs. It was as if the youth were a liability in the church. Seeing this, I tried to find the cause of their setbacks, their lack of involvement in leadership roles and active participation in youth ministry. The cause appeared to be linked to cultural beliefs which characterized the community, and were emerging in the church. The youth were not considered a part of the decision-making, because it was thought that they had nothing good to offer. In Roger Dudley's and B. V. Gillespie's initial analysis of the Valuegenesis research (1992), they report that "a value of service involving the youth proved to be the most important predictor of mature faith" (p. 279). If faith is to grow, greater involvement in service and outreach activities needs to be fostered. The biblical principle of youth involvement in leadership roles needed to be incorporated into youth ministry and superimposes itself on any culture. I felt encouraged to explore the biblical principal of youth leadership and to identify its theological foundation.

\section{Statement of Problem}

Young people currently comprise two-thirds of the 1,500 members of the

Bantama Seventh-day Adventist Church in Kumase, Ghana. Despite a continuing 
increase in the number of young people, only a few of them participate in youth activities because of the lack of formal programming or clear directions for youth ministry in the church. The result is lack of spiritual connections with the church and major behavioral problems among the young people who are left to their own activities. Consequently, parents are not allowing their children to attend these youth-initiated activities, resulting in friction in the homes.

\section{Justification of the Project}

There has been a significant decline in the involvement of the young people in the spiritual activities of the Bantama Seventh-day Adventist church over the last five years. A statistical membership report of the Bantama Church in the Conference office indicates that from the years 1999 to 2005 , one hundred and fifty young people were baptized into the church, but that many of them do not attend the spiritual programs of the church.

The youth activities have continued to function under the name Adventist Youth, a traditional name that does not attract young people to join. Parents continue to be unhappy about the lack of leadership in the youth programs, and they do not allow their youth to participate. Unpleasant behavior at home is attributed to the lack of supervision of the youth in their church-related programs.

The church leadership has not focused on the spiritual development of the young people, and this has had a negative effect on their spiritual growth pattern. The role of the local cultural belief in the community that parents are the head of the family and youth are to be seen, but not heard, has emerged into the church, thus depriving the young people from decision-making in the church. The youth feel that their parents and church leaders are imposing regulations on them and this has caused tremendous friction 
between the youth and the adults: church leaders and parents.

\section{Description of the Project Process}

Certain steps were taken to proceed with the research for this study. The first step was to develop a theological foundation for youth ministry by exploring themes in the

Old Testament, New Testament, and the writings of E. G. White that relate to youth. The literature review included books and articles dealing with strategies for youth ministry. Special needs of the youth, both spiritual and social, and church-based youth ministries, with emphasis on the Adventist church were examined. A theoretical and practical study, the research focused on the characteristics of youth ministry. An analysis was done of the problems, issues, and concerns of the Bantama Church in the context of youth ministry. Information was collected through a series of interviews. Since the Bantama Church is a multicultural church, it necessitated some study of the differing worldviews of the members.

A strategy was developed for youth ministry in the Bantama Seventh-day Adventist church; which included new worship models for spiritual growth. The strategy also encouraged a relationship-based program for the young people. An on-going process of spiritual involvement was established, with active participation in spiritual activities in the context of the Bantama Seventh-day Adventist church.

This study is organized into six chapters. Chapter 1 is a general introduction, which highlights the problem, justification, and purpose of the project. Chapter 2 gives the biblical foundation for the involvement of the youth in diverse ministries. Chapter 3 presents a literature review in the following areas pertinent to this study: 1) understanding young people, 2) youth ministry in a multicultural/multiethnic context, 3) youth 
leadership issues, and 4) models for youth ministry. Chapter 4 develops an incarnational model of ministry involving youth participation. Chapter 5 contains the results and the application of the model. Chapter 6 contains a brief project report for publication, conclusion, summary, and recommendations for further development of new models. 
CHAPTER 2

\section{THEOLOGY OF YOUTH MINISTRY}

\section{Introduction}

God leads in the lives and work of everyone, shaping them for ministry, by allowing them certain experiences in their formative years. Learning to follow God's leading as a youth builds the foundation for future ministry. Theology needs to be securely grounded in biblical revelation (Gane, 1993). The Genesis story states that God created humanity in His own image (Gen 1:26), revealing that humanity is a special creation, brought into existence to be in close communion and have a personal relationship with God. Gane emphasizes that theology is "speaking about God" or "knowledge about God" (p. 51). What theology seeks to do is to spell out what we know about God as He is revealed in the Bible and especially through the incarnate Jesus (John $1: 1-3)$. The basic meaning of true knowledge and its application to theology is what Wilhoit (1991) describes as "facts, feelings, and proper relationship" (p. 42).

A theology of youth cannot be limited to mere formal statements or sophisticated systems of interpretation and technical terms. Hebrew and Greek terms related to youth signify the relevance of youth and how God can use youth in ministry in the prime of their lives. Therefore, the ministry of youth should affect everything they do and influence the type of message they bring (Richards, 1981). With this background in place 
some specific biblical terminologies show how God worked with young people in Bible times.

\section{Theological Terms for Youth}

Understanding the basic meaning of the biblical terminologies of youth in ministry requires analytical word studies using commentaries, biblical dictionaries, and some encyclopedias. Emphasis will be given to how Hebrew and Greek words explain the theological implications of the call for young people to lead out in ministry. Different terms appear in both Old and New Testaments about youth. Each of these terms has its own historical background, yet they are all used to portray young people in different aspects of ministry (Dean, 2001). Theological understanding of youth ministry for much

of the $20^{\text {th }}$ century meant ministry with high school and, more recently, junior high students. However, today, a youth may be any young person between the onset of puberty and the time of entry into the workforce (Dunn, 1997). Santrock (1986) uses the word "youth" to describe the period between adolescent and adulthood (p. 387). However, a youth is generally a person between twelve and eighteen years whereas a young adult is also between eighteen and thirty five years (Harder, 2009).

During this period in the life cycle, adolescents acquire an identity, a coherent sense of self that encourages them to participate in social activities. Youth ministry, therefore, properly addresses young people in any of these stages (Dean et al. 2001).

\section{Hebrew Terms}

The Hebrew Scriptures have three basic terms for youth, each with different meanings. They appear in the Hebrew text with reference to a young girl or young boy, 
and sometimes refer to children in relation to their divine tasks.

\section{$\mathrm{Na}^{6} \mathrm{ar}$}

The singular masculine form of na'ar and its plural neurim ("youths") is a term for youth. They occur some 235 times in the Old Testament, including feminine form na 'ara ("girl," often "maid"). The word was used to refer to a boy receiving God's revelation, for Joseph at seventeen (Gen 37:2) (Bromiley, 1979, p. 1165). According to Buttrick (1962), na "ar is the most common Hebrew term for "young" or "youth." He further explains that na' $a r$ is at times used for infants (1Sam 1:22; Judges 13: 8), but can also refer to someone fully grown (p. 925).

However, na 'ara (feminine, youth) denotes a young woman who is of marriageable age, and generally translated virgin, in which case na'ara is translated "young" (Buttrick, p. 1165). Both genders were used interchangeably in reference to their prime who are capable of carrying out human and divine responsibilities (Lev 27: 3). Therefore, for the purpose of fixing a scale of values, twenty years appears to be presumably prime of life (Buttrick, p. 925).

Ortiz (1997) maintains that youth in both Testaments were characterized not only by their activity, but also by the recognition and development of their talents (p. 9).

\section{Bahur}

In the Old Testament bahur has two different meanings, young man (noun), and chosen (participle). The root word bahar explains bahur for "warrior," or "hero" (Loewenstamm, 1980, p. 49). It seems, therefore, that, like na 'ar, bahur was used for one in the prime of manhood (1 Sam 9:2; Prov 20:29), but unlike na $a r$, not of a person any 
younger (Bromley, 1979, p. 1165). According to Harris (1981), the Old Akkadian and Babylonian text renders the root meaning as "to elect, "to choose." Baḥur, therefore, shows the extent of how God's love is extended to the young people "as they are equally chosen" as God's workers (p. 100).

\section{Bahar}

The word, in nominal form, denotes young men, properly chosen youth, implying strength and beauty in character. Apart from these expectations, the tern in verbal form is also used to express that choosing has ultimate and eternal significance. God chooses people (Ps 135:5), certain tribes (Ps 78:68), and specific individuals for a divine task (1 Kgs 8:16; 1 Chr 28:5; 1 Sam 10:24) (Harris, 1981).

\section{Greek Terms}

Like Hebrew, the Greek Scriptures also have different terms that apply to youth. The Greek terms neos (young) and neanias (feminine for a young woman) are found in several places in the NT. These words will help the reader explore the Greek terms and reach a meaningful interpretation that reveals how God could use many young people in ministry.

\section{Neos}

The most common word used in the New Testament for youth is neos, which according to Danker, can also refer specifically to a young man. Neos has the nuance of "fresh" and "young" indicating a young person (Danker, 2000) in reference to Timothy. Paul used the same term neos for not to allowing anyone to "look down upon him" 
because he was young (1Tim 4:11). According to Vine (1985), there is an instance where the term neos refers to a new and "young man in ministry, like Titus in Titus 2:4 (p. 360).

\section{Neanias}

Neanias (masculine nominative singular) designates a young man, but when used in the feminine form neania, means woman. According to Horst \& Schneider (1981), both genders often refer to young man and woman until about the age of twenty. The singular is used for the young rich man in Matt 19:20, 22; the young man who fled naked in Mark 14:5; the angel at the grave in Mark 16:5; the young man of Nain in Luke 7:14; and, the nephew of Paul in Acts 23:18, 22. Young man and woman (neanias, neania) are also used in Greek writings of the day for those about twenty-four to forty-five years. Both terms suggest that God used both genders in their youth in diverse ministry (Gaebelein, 1991, p. 32).

\section{Neaniskos}

Neaniskos, a diminutive of neanias, "youth, or "a young man" occurs in Matt 19:20, 21 and Mark 14:51. This is the only place in the Gospel of Mark where neaniskos (young man) occurs. Scholars have argued about the identity of this young man. The phrase "sunkolouthei autö" could be translated "was accompanying him, "was following him" or was attempting to accompany or follow him. The significance could either be that the young man was in the entourage of Jesus up to the time of his arrest, or that when Jesus was arrested, he tried to follow him to join the group who took him away (Collins, 2007, p. 354)). This is a clear indication that "young men were in the group of Jesus during His earthly ministry (Behm, 1977). 
Youth called as Kings and Queens

The Scripture contains evidence of the leadership of young people. Many young people were called into ministry as kings and queens. Among them are Esther, David and others whose lives were set apart from other young people in a close connection with God, with a willingness to be led by God. One of the greatest figures as a queen in the Bible times was Esther. I will show briefly how by her surrendering to God, she was used to liberate the Jews.

\section{Esther}

The story of Esther demonstrates God's plan of deliverance through the trembling faith of a young queen's petition. The Scriptures refer to Esther as a young and beautiful woman who became queen in Judah (Esth 2:7, 9,22). God raised Esther from an orphan to royalty "for such a time as this" (Esther 4:14). According to Nosotro (2009), God called some young women to take a leadership role (http://www.hyperhistory.net). She used her influence to reverse all human plans for the killing of the Jews. This example affirms an important desire of God to use young people in ministry in these last days.

\section{David}

God's choice of David as king of Israel was his determination to use young people in ministry. After Saul's rejection, Samuel's choice of Eliab to replace Saul as king was rejected by God (1 Sam 16:6,7). David began his career as an aide at the court of Saul, Israel's first king, distinguished himself as a warrior, and later emerged as king of Israel. David was chosen a king of Israel when he was the "youngest" in a family of adults (1 Sam 16:11,12). David showed that he possessed not only youthful strength 
(baḥur), but also a fearlessness born of confidence in divine power (Hwan, 2001, p. 27). Regardless of size, strength, height or years, God has a place for youth in ministry just as He does for adults. Campolo (1983) writes, "Young people want a church that will provide them with concrete ways to become agents of God's revolution" (p. 9). White (1958) agrees with Campolo that "young people must be partners in finishing the gospel commission" (p. 196). God chose David, a young shepherd, when Jesse was ignorant of his son's potentiality. Ortiz (1977) states, "By keeping the sheep, he learned to be uncorrupted by the world. There he obtained a sense of responsibility and developed the qualities of leadership to be used as king later on" (p. 27).

\section{Youth Called as Prophets}

Prophecy is one of the most important ministries in Scriptures. Prophets were chosen among the Israelites to transmit God's will, call for repentance, and announce future occurrences. Although God used other methods of communicating His messages (Heb 1:1,2), Scripture indicates that "prophets" were the most recognized form of divine communication (Amos 3:7). God used many young people as channels of communication to accomplish His divine purpose. Jeremiah was among the amazing brave, faithful, and brilliant young prophets through whom God spoke His mind. God called them to the prophetic office while they were still young. Some left their native places for the work of God.

\section{Jeremiah}

Jeremiah, one of those who had hoped for a permanent spiritual revival and reformation under King Josiah, was called to the prophetic office while he was still 
young (Jer 1:1-4). As a member of the Levitical priesthood, he had been trained from childhood for holy service. In general, some scholars believe that Jeremiah's call came at about the age of twenty (Honeycutt, 1981, p. 305). While he was young, Jeremiah found himself in a chaotic period of national destruction and personal disorientation. He was called to "prophesy the certainty of divine judgment upon the hopeless and disobedient political and religious establishment of Jerusalem" (Honeycutt, 1981, p. 185). Honeycutt further maintains that the ministry of young people is described in the Bible, not only through the lives and experiences of the prophet, but also through the spoken word of the prophets. God's call to Jeremiah in "his youthful age gives voice in his time that contained and continues to offer opportunities for young people in church activities" ( $p$. 185). Borthwick (1988) observes, "Leaders often think of the youth as immature and unwise; and they doubt about their effectiveness. But God does not limit his call to the young people for service, just as he called adults into prophetic ministry" (p. 18).

\section{Youth Called as Priests}

In pre-Mosaic times, the office of priests was occupied by the family or head of a tribe (Unger, Harrison, Vos, \& Bartber 1988). Priestly individuals were found among the young men who offered burnt offerings to the Lord (Exod 28:1). The young men served as priests until the Aaronic priesthood was instituted. Later on, the Lord asked Moses to "set the Levites apart" to do the "work of the Lord" (Num 8:11, 14). Levites, aged at least twenty to twenty-five, were assigned to the priestly work (Num 8:23-25). Among the vast numbers of priests were some young ones like "Phinehas who heeded to God's call to service" (Tenney, 1976, p. 850).

Phinehas was the son of Eleazar 'the Priest' (Josh 22:31). During a time of 
apostasy, an Israelite man defiled a Medianite woman, resulting in Phinehas killing them both with one spear (Num 25: 6-15). His loyalty and bravery as a youth for God quenched God's anger to destroy all of the children of Israel, because he made atonement for their sins. (Tenney \& Barabas, 1976, p. 777). God declared that Phinehas and his sons' sons hereditary were to receive divine recognition: a covenant of Peace and the Covenant of an everlasting Priesthood for all eternity (Num 27:7-13). God's desire to use youth in all generations is still there.

\section{The Importance of Youth}

The importance of youth dates back to the history of their creation. In the Genesis account of creation, God's pronouncement, "it is good" (Gen 1:31), also reflects on the offspring of the youth. It has been said that God did not call the qualified but called to qualify. In the biblical illustrations, it is apparent that the characteristics of the young people who depended on God are important in predicting success. To consider the importance of today's youth, Mueller (1999) exhorts parents to close and eliminate the cultural-generational gap in their home (p. 375).

Barna research (May, 2001) shows that when young people are regular and active members in the church, the leaders have a lifelong influence on them. The majority of adults who attended church when they were young are still regular and active members. Many youth go to church only as church-goers but with no purpose (Barna, 2001).

\section{George Barna states:}

The research is very clear: if the young people are considered as partners and not mere followers, the chances of securing the future of the church will be high. Because of granting them the privilege to be partners, they feel important and ready to have a tremendous influence with their peers (Barna Research Online, 2001). 
This means that young people have the unique importance of being the people of God today and the promise for tomorrow. While it was once considered acceptable for a church to simply discipline youth without empowering them, it is no longer acceptable. A church that takes the mission of youth seriously considers its ministry with youth (Black, 1991, p. 13).

\section{Commitment to Service}

It is believed that commitment to service involves more than a mere decision to follow Christ. Youth who are committed to Christ will give evidence of some characteristics in their lives. As young people realize the importance of their calling, they are ready to respond to work. They want to follow many of the biblical examples of young people affirmed by God because of their genuine commitment and devotion to Him. To affirm their commitment to Jesus, they want to adhere to the eight characteristics of Christian youth proposed by Strommen and Hardel, 2000:

1. Trust a personal Christ,

2. Understand grace and live in grace,

3. Commune with God regularly,

4. Show moral responsibility,

5. Accept a responsibility in a church,

6. Demonstrate unprejudiced and loving lives,

7. Develop hopeful and positive attitudes, and

8. Engage in mission and service (p. 130).

These characteristics parallel those that the apostle Paul enjoined to Timothy:

"Don't let anyone look down upon you because you are young, but set an example for the 
believers in speech, in life, love, and purity" (1Tim 4:12; cf. 6:11-12).

The church must assist the youth in learning what it means to take up one's cross and must prepare them for the demands of self-sacrifice. Once young people are fully recognized and accepted, they enjoy the privilege of becoming partners in sharing, contributing, and participating in church activities. It will also be observed that their time with God will be intentionally one with commitment and devotion.

\section{Devotion}

One of the profound characteristics that most likely motivated God to use young people in ministry is their devotion. This is evidenced in a passionate desire on the part of young people to seek God as found in the life of Daniel and his three friends, Joseph, and others (Dan 6:16-17; Gen 37:12-20). The quality of their love and loyalty to Christ was measured by the depth of their devotion and love for God.

Joseph in his prime has become a model to youth through his devotion manifested in the trials of life. White (1958) writes, "The desire to gain the favor of the Egyptians could not cause him to conceal his principles" (p. 214). Maybe if Joseph had been overcome by temptation, he may have been ashamed of the religion of his fathers, but he made no effort to hide the fact that he was a worshiper of Jehovah. Gaebelein (1991) maintains that Joseph's choice has been part of the basis for God's willingness to choose youth through the grace of Christ that they may be transformed into His image for service" (p. 234).

Opportunities for youth to explore the meaning of life as they are experiencing it will reshape their understanding and responses to God's Word (Richards, 1985). Greenleaf (2001) writes that leaders, must therefore, have more "armor of confidence 
when dealing with the unknown" (p. 41). Joseph is perhaps a standard human illustration for young people in their future leadership (Gen 50:19-20). Like Joseph, Gideon's devotional life sets the tone for youth in this contemporary generation. Tenney (1976) recalls that the dynamic leadership of Gideon that followed was not the result of public demand, personal desires for leadership, or high opinion of his own abilities, but only as a result of his devoted life to God. The desire of youth to participate in church activities increases when they are inspired to be devoted to God. In his study (Bell, 2003) maintains that Gideon acted by faith-based optimism and demonstration of "concern for fairness while his heart beat with urgency to know God" (p. 61). These testify that when young people spend time with God in their personal devotions, their lives will reflect their calling for service to God.

\section{Theological Reflection of Ministry}

Many biblical scholars believe that theological reflections may lead to the assumption that theology controls activities in Christian ministry. Others indicate that ministry comes first and dominates in leading theology, which in turn influences ministry. Anderson (1979) noted that "ministry precedes and produces theology. Ministry is determined and set forth by God's own ministry of revelation and reconciliation (p. 7). No ministry can ever be successful without God's initiative and leadings. Jesus' death on the cross to redeem fallen man and restore him to the original image was because $\mathrm{He}$ knew it was His Father's plan. Our theological reflections need to be based upon this sound biblical foundation.

The Genesis story says that, in the beginning, God created man in His own image, which signifies that man is specially created, in order to be able to communicate closely 
with and have a personal relationship with God. Some biblical stories give an account of fallen human beings "who, through an encounter with God, recognized their need of Savior, and received insights into God's plan of salvation" (Gane, 1997, pp. 53, 55). In the Genesis account of the fall God, promised to reverse the situation that was caused by sin by sending His only Son through the Holy Spirit in the seed of a woman. God takes the initiative in fulfilling His promise regarding the plan of salvation. The details of this mission to rescue fallen human beings are more clearly shown in the prophecy pointing to the redemptive work of the Messiah that was fulfilled in Christ. Stevens (1985) maintains that Christ's primary ministry is to the Father for the sake of the world and not to the world for the sake of the Father. He loves the world and seeks its good and sets its agenda. Therefore "theologically there is only one ministry, and that is the unique ministry of Jesus Christ." (p. 4).

The impact of theological learning however, is not limited, to proper hermeneutics and teaching. The depth of one's personal relationship with God is directly affected by the genuineness of one's factual knowledge of Him. Theological foundations are just the raw materials necessary for developing the life and ministry that reflect true knowledge of God. However, when the knowledge gained impacts the life of youth, it then evokes the theology. Young people must be the primary resource in the ministry and theology that shapes what they learn of God through ministry (Dunn \& Senter, 1997). Borthwick (1996) points out that "we must see beyond our ministries and cultures and emphasize the 'global importance' of youth ministry. The church needs to seriously approach youth ministry as followers of Jesus Christ and willingly evaluate the challenges of the words when Jesus reminds us that 'whosoever welcomes one of these 
little children in my name, welcomes me; and whoever welcomes Me does not welcome but one who sent me' (Mark 9:37 KJV)."

Youth ministry that is founded upon a spiritual foundation needs to be the focus of the church today. The pastor must show interest in all the programs of young people. He must also involve the elders in the activities of youth so they will know that the church supports them. Paul Borthwick agrees that the decisions made during the adolescent years will influence the rest of their lives. Moreover, many young people formulate their worldviews, wrestle with their sense of personal purpose, and determine lifestyle values during their adolescent years. They explore their sexuality, choose career directions and marriage partners, and make choices regarding their personal faith (Borthwick, 1997). It is here that many youth workers are needed to come alongside young people in these transitional years to help them make right decisions and choices. Youth ministers need to be theologically informed by the dynamism of young people and by Christ in order to lead them.

\section{Importance of Ministry Goals}

The privilege of ministering with youth is a gift of God that brings profound joy and a sense fulfillment to those who carry out the mission (Strommen, Jones, \& Rahn, 2001). While youth ministers experience self-doubt and concern over various issues and aspects of their chosen profession, they also experience deep feelings of personal satisfaction from their work. This sense of joy is the product of specifically fulfilled ministry goals that are related to the areas of personal as well as interpersonal relationships. When youth integrate leadership into discipleship, "it will not only cause their great spiritual maturity, but will increase their numerical growth and absolute 
participation in spiritual programs" (Nygren, 1999). Theology must seek to be in touch with the hearts of young people and with Jesus. We should not belittle the contributions of youth but encourage them to a higher standard of ministry. In the parable of the wise and foolish builders (Matt 7:24-26), Jesus demonstrated ministries with young people whose foundations are firmly anchored either in sand or on rock.

The difference between those who succeed in youth ministry and those who collapse under its weight lies in the substance of the foundation. Those who fail may not have built their ministry on theological bedrock, but, rather on shifting sand (Dean, Clark, \& Rahn, 2001, p.15). It is supposed that all decent theology should begin and end with practice. The theological foundation of youth ministry must be grounded on things that young people believe and can practice. To fail to think theologically about youth ministry is like "substituting a religious career for a holy vocation." Preparing to serve young people must be more than preparing packets of models, strategies, and theories, which may not be relevant to the world in which they live. Youth must first have "theological rocks," the conviction about who God is and what God is about that is normative for everything they do (Dean et al., 2001). These are the convictions that call the youth to faith and ministry and also govern their ministries.

Theological foundations affect the development of youth programs, the approach of sermons, and even their relationships within the church and with their parents. Practical theology that goes along with Christian actions, principles of discipleship and ministry must be reemphasized in the church. This preparation of youth toward Christian action will invite God to use them to transform the world in their encounter with Jesus. Youth can achieve this only when their theology is practical and is intimately connected 
to the practice of ministry. Collins (1997) says that it is the practical aspect of theology that youth are called to: to be disciples whose obedience to God in the church and in the world put the truth they claim into practice. Youth ministry that emphasizes evangelism, without simultaneously giving youth opportunities to serve in substantive ministry, neutralizes discipleship. It also seeks Christian action without a growing relationship with Jesus, thus reducing actions to simply good works.

\section{Faith and Practice}

The apostle James drew a sharp demarcation between the expectations of Christian theological practices when he wrote about faith and works (Jas 2:10-12). Youth ministry practices a kind of deliberate theological reflection on Christian action. There is no sharp line between practical theology and theology in general. British theologian Ballard (1999) points out that "all theology is in the service of the community of faith, and therefore all is essentially practical" (p. 142). Moreover, when young people understand the concept of practical theology, it weaves together multiple strands of theological reflections of God in particular. It also creates concrete situations that call for action. The objective of youth ministry is to help youth grow a faith that is mature enough that they can use that faith to discern faithful Christian action. One of the basic purposes of the SDA Church at Bantama must include a ministry that will help adolescents become practically related to Christ and also create opportunities for them to participate in ministry.

\section{A Call to Ministry}

In the Old Testament, God's plan to reveal Himself to the world was for the world to come to Israel. The Old Testament idea was that Israel was to be a nation of priests. On 
the contrary, the New Testament portrays the idea of God's people proclaiming the gospel in the world (Rev 14:7). The central theme of the strategy in the New Testament is the doctrine of the priesthood of all believers. The fact that Jesus is our Model implies that we are called to ministry in our personal relationship with others. We need to involve our young people by empowering them "so they will become part of the ministry, and also know that it is for them too" (Gane, 1997, pp. 54, 55). This is a call to service. The result of ministry to youth will bring them to the place where they recognize and accept Jesus as their personal Savior. It will continue to promote the spiritual growth of these new disciples and also seek to empower them to continue the same ministry for other people. Timothy is a sample character in Scriptures, who, as a young man, shared in the full responsibility of ministry ( $1 \operatorname{Tim} 4: 12 \mathrm{KJV})$. His ministry, like that of others, was to do works of service and to build up the body of Christ (Eph 4:12). There is nothing in youth ministry that can work except as young people have a better relationship with Jesus and simply realize their calling. Realizing that youth want to hear from God, Yaconelli (1999) considers helping connect youth and Jesus as a spiritual exercise.

When they are listening to Scripture in a quiet setting, they experience the God they long for. Thus, no theological foundation is genuine that does not work a reformation in the lives of the Christian. The importance of theology must be exhibited through ministry as a guiding principle for the Christian daily walk with Christ for the youth and their ministry. When their philosophy in ministry is centered on their partnership with God, they will sense the empowerment, guidance, and acts of God (http://findarticles.com/p/articles). Brown (1965) points out that "by observing the youth" they can produce much more change in their behaviors than just being theoretical (p. 
387). Church leaders should have it as their responsibility to encourage the youth and encourage the development of values as expressed in their lives rather than merely to belong to a ministry. The concept that practice and theology need to be interconnected is based on Bible teaching, the principles of servant leadership, and the example of Christ. This approach needs to be a part of the exhortations to young leaders (Richards, 1985). When the church understands that youth need a model to imitate, the adults will be conscious of the kind of lives they portray. Though the theory may be necessary, young people want to see what they hear. White (1930) indicates that "their influence may tell for the truth of God" (p. 21).

\section{Summary}

Youth ministry must be understood in the context of God's call for both adults and young people to participate. The understanding of theology must seek to be in touch with Jesus for spiritual advancement. This spirituality must be revealed in the lives of the youth as demonstrated in their faith and practice. God chooses different people for His purpose at different times. Chadwick (1991) observes, "The single desire that dominates the search for delight was simply to love and involve the youth in all you do" (p. 24).

Youth may lack natural qualifications to lead or to interpret events for the whole nation. The Lord, however, will anticipate their objections because He knew them and appointed them before their birth. His will once revealed for them cannot be stopped. It should be noted that the Old and New Testaments cite some young people who were highly regarded, given responsibility, and used by God in various ways in ministry. This gives a clear message about how young people should be treated within the church body. God's foreknowledge and, particularly, His calling of them must be appreciated. The 
adult leaders of the church should now understand that youth are partners together in ministry. The church, therefore, should not belittle the contributions of the youth but encourage them to a higher standard of ministry. Ortiz (1997) argues that the original words that are used for young people in both Old and New Testaments represent different age groups (p. 32), so the concept of their involvement in ministry is clear (p. 32).

Neos, the most commonly used word in the New Testament, carries the meaning of young or new. It occurs in several places in both Testaments referring to those ranging from twenty to twenty five years. It appears to be used to mean an inexperienced person. However, in the Scriptures young people were found to be participating in ministry as kings, prophets, and priests who performed vital responsibilities. What determined their success was not being young, but their connection with God. To God, gender or age difference was not to hold back the ministry through kings, prophets, and priests. God was able to choose young people, involve them and also provide appropriate training for them. The same God is ever ready to see young people in different ministries. 


\section{CHAPTER 3}

\section{LITERATURE REVIEW}

\section{Introduction}

Understanding youth ministry requires insight into the methodologies and assumptions in the heart and mind of the youth pastor. Robbins (2004) develops the ideas of "discovering and winning" as a foundation for the ministry professional's practice. It is an adventure about facing difficult goals and pursuing real challenges; it is about people, in this case youth, who literally are to be discovered, won, and involved (p. 11). This discovering and winning of young people is a direct application of the evangelical understanding of continuing the work of Jesus "to seek to save the lost" (Luke 19:10). The context for this reflection is the organizational culture in which the local church is operated. In the case of the Bantama Church, the focus is on hoping to align their youth ministry more effectively with the teaching of Scripture and the example of Christ. A metaphor for the change needed in youth ministry can be found in Eccl 12 . Here, the writer outlines the physiological transition from youth to adulthood. The chapter begins with the exhortation to remember your Creator in the day of your youth, which sets up the reader for the ensuing verses, describing the reason for his urgency to be proactive before it gets difficult. The writer reminds us that when one grows old, he will not be able to do as much as when he was young because his body does not function as well. 


\section{Understanding Young People}

The escalating risk facing young people and their lack of involvement in church programs point to the failure of the church to understand the culturally-driven course of their lives (Creasy, 2000, p. 9). This study is framed within the context of existing articles, papers, dissertations, personal interviews, books, and other documents that deal with scientific research on youth ministry and the understanding young people and how to co-opt them into other programs. A thorough reading of literature explores four major themes: (a) understanding young people, (b) youth ministry in a multiethnic/multicultural context, (c) youth leadership issues, and (d) models for youth ministry.

Black (2004) discovered that the reason why young people are misunderstood is not because they fail to be attracted to the church. He argues that college students and young adults may be struggling with newfound freedoms and poor management skills, resulting in irregular church attendance and a lack of involvement in spiritual programs (p. 13). It is clear to note that no connection exists between the religious commitments of adolescents and the life patterns they establish (Black, 2004). It must be remembered that youth come from a variety of life experiences. Some have had good days, and others have experienced terrible days. In dealing with them, Wallace and Tyrone see that our understanding of them must connect us with them to be able to assist them in their faith development. They also believe that religious youth generally make better choices and lead healthier lives than adolescents without any religious affiliation, especially when they have good connections with spiritual adults (Wallace \& Tyrone., 1998, p. 25).

Dilulio (2002) maintained that if the youth are understood in their worldview, then "religion can improve their well-being and restructure their specific social problems 
(pp. 50-64). This will not only improve the faith of young people, but will also develop a better interpersonal relationship with their parents, resulting in a more peaceful home. Strommen et al (2001) argued that the only way to reach them is to introduce the gospel and let the relationship with Jesus shape their attitudes and create a people who stand in marked contrast with significant numbers of other young people (p. 183). If Bantama Church leaders were to target the youth population and close the gap of the relationship between older and younger members, they could exert a mighty influence in their lives. Strommen and Hardel (2002) say that the greatest concern of Christian parents and church leaders revolves around whether or not their children will be committed to Jesus Christ and to His service. In 2002, the statistics of the Central Ghana Conference of Seventh-day Adventist Church showed that more than thirty-five percent of the young people of Bantama Church who attended church as children had totally withdrawn from being involved in the spiritual programs by the time they were twenty. The question is how the church can understand youth, draw closer to them, and involve them in church programs. The basic answer lies in changing the mindset of the parents and church leaders. They need to revise their understanding of young people and the approach to their ministry. Dean and Foster (1988) argued about the inconsistency of wanting youth to be in the church and keeping them from an active role in church activities. They state that "numerical involvement and growth in youth ministry must not exist as its primary goal" (p. 311). Churches need to be concerned with seeing the lives of young people transformed by the renewing work of the Holy Spirit so that they understand their place in the body of Christ and fulfill their calling to advance God's Kingdom.

The youth will misunderstand church leaders if they do not see them interested in 
their spiritual welfare. Gane (1997) made it clear in his dissertation that there is a "relationship between youth ministry and commitment to Seventh-day Adventist fundamental beliefs and values. Youth with high exposure to youth ministry had a lower likelihood of involvement in at-risk behavior than their peers. More exposure to youth ministry meant a greater likelihood of the youths satisfaction with their church and also of intention to be involved in it in the future. They showed higher levels of concurrence to church standards, saw the Pastor as having more influence in their faith development, and were much more positive in their perceptions of the church" (p. 2).

Influencing their spirituality entails intentionally finding ways to integrate adolescents into the church as a whole, not isolating them by age-segregated programming In dealing with various people, Jesus did not alter his message in order to attract more followers; He let people walk away rather than sacrifice truth (John 6:60-66). Young people must be willing to sacrifice aggression before sacrificing Scriptural teaching that calls for a united community of believers working together for the same cause. Marcum (2001) notes that "this principle can place them in situations where great mountain-top experiences can happen" (p. 15). Bantama Church will grow in a lasting relationship with the youth as they understand their worldview and gradually bring them into their fellowship. When they recognize the essential nature of the church in their spiritual growth and see the importance of its activities, it is likely that they will not neglect their participation. Instead, because they experience connectivity with church programs during the spiritual, pivotal stage of adolescence, they will continue to remain active in the church. Young people are misunderstood and are considered disobedient. 


\section{Changing Times with Young People}

Young people seem uncontrollable at certain times in their lives. David Kinnaman evaluated the findings on the sustainability of faith from the teen years into the twenties. Much of the ministry of teenagers needs overhauling not because churches fail to attract significant numbers of young people, but because so many of those efforts are not creating sustainable faith beyond high school. 'It's not entirely surprising that deep, lasting spiritual transformation rarely happens among teenagers - it's hard work at any age, let alone with the distraction of changing times with the youth" (Barna, 2006, www.barna.org).

In the light of this indictment, Soren Oestergaard and Simon Hall (2001) call us to "theology and praxis in extremis - a process where we reflect critically on some of the core issues about being the church and our current approaches to the young people" (p. 211). The church and colleges must equip youth pastors with good critical-thinking skills (Harris, 2005, p. 12). Gillespie \& Donahue (2005) note, "As any speaker knows, youth are a tough crowd, and even harder to reach when times change with them (p. 47). They believe that young people are curious to know what is happening, especially about adults and what the activities of the church stand for. They rarely get along with the church, let alone participate in their programs. Barna (1999), a specialist in youth research, said that "their changing attitudes may be the sign that they are getting too old to do relevant ministry" (p. 4). In 2004, Gillespie conducted a study to examine the careful portrait of young people in two generations. One of the conclusions they reached was that many religious educators believe that teens are religious. However, nothing helps us to understand the youth more than living with them through their teen years and directing 
them in changing times (pp. 49, 50). Since most youth find change uncomfortable, it becomes necessary for change agents to plan their strategy carefully to ensure that they make progress without creating undue discomfort (p. 57).

\section{Identity Formation}

According to Erickson (1968), the youth's life development goes through a series of crisis that one must master before progressing to the next (p.55). There have been a considerable number of efforts to study the personal identities of youth by means of questionnaires. The purpose was to discover what instigates youth to come up with certain decisions if even they can negatively affect their lives. James Marcia (1980) developed an interview technique whereby he was able to identify and describe four identity types of adolescents. The first type is what Marcia (1980) calls identity diffused youth. These youth have not thought seriously about goals, values, and beliefs, nor have they made any decision in those areas. They are relatively aimless and uncommitted to any set of goals, values, and beliefs. The second type is identity foreclosure. They are characterized by not having experienced crisis, yet express commitment to goals, values or beliefs. These adolescents are mostly motivated by their parents for decision. "If it is right for my parents, it must be good enough for me." Identity moratorium is the third where the adolescents are distinguished by the appearance of active struggles to make commitments. The fourth is identity-achieved youth who have not only experienced crisis, but are committed to decisions made in regard to critical life issues (pp. 22-29).

These crises of identity are the major issue that adolescents usually confront and have to deal with (Marcia, 1980, p. 99). Atkinson (1997) says, "During the formative teenage years, young people face the crisis of discovering how they fit into society and 
what roles they will play in life" (p. 19). However, as we talk and think about these identities, we are disturbed whether as Christians we have a clearer sense of them. Young people want to know about the future through the experiences of those closer to them. The source of these identities comes only when youth are connected with God as Paul inspired young Timothy to "study to approve himself" (2 Tim 2:15) for a closer connection with God. If the church moves the youth forward through the primary stages of unawareness and then into awareness, we are maturing the students. They identify themselves and grow spiritually (Robbins, 1990, p. 43).

\section{Young People and Modern Technology}

The lives of young people are intentionally integrated with modern technology Many of these technologies have fundamentally transformed young people in the way they value faith. Borthwick (1990) observes that youth around the world are bombarded with media far more than their parents ever were (p. 9). He observes that cable television and computers are becoming universally accessible and incessant advertising. It is a fixture virtually in every culture around the world. Many of the images teens are confronted with come through these media (p. 9). According Kenda (2007), the Pew Internet Study on Teens and Social Networking maintained that $66 \%$ of social networkers use privacy settings are mostly teens. The major reason for the transformation is making "friendships," which is a big part of the MySpace experience (p. 34). It has provided the basis for terrific Bible studies. The young girl who is trying to get a boy's attention wants him to know that she has accessed his site thirty times in the last hour (Kenda, 2007, p. 34). Surprisingly, the use of social networking has to do with the way technology allows users to express themselves. 
Barna (1992) states that the lives of young people are alarming because of technology and electronics. They are more than simply the generation that was raised by television (p. 99). Numerous studies have shown the enormous influence of television on the minds of today's young adults around the world. It is important for anyone in youth ministry to understand and be sensitive to these symbolic expressions of separateness. Even though it has been argued that these forms of technology are more Western than that coming from any other part of the world, the influence is generally everywhere now (Richards, 1985).

\section{Underlying Impact}

Technology is slowly shaping the way teens view themselves, the way they maintain friendship, their participation, and even their understanding of who God is in their lives (Kenda, 2007, p. 42). The use of such technologies can be useful for youth programs if proper supervision is put in place by the adults. As we come to know teens, and spend time with them, we will become more and more attuned to their ways. Campolo (2000) observes that the students with whom we work were born into a culture in transition, and children born today are entering a thọroughly post-postmodern world.

However, this is not to say that all students will adopt postmodern traits, but postmodernism will be reigning school of thought, and post-modernity will be the reigning element on young people's culture when the students are addicted to many of the images on computer (p. 29). Many communication scholars agree that most of the information we get about relationships actually comes in nonverbal form cues. Furthermore, Barna Research (2000) found that although greater numbers of middle school and high school students attend church than baby boomer parents, only one teen in 
three plans on continuing participation in church activity upon reaching adulthood. $\mathrm{He}$ concludes that "this is the lowest level of expected participation among the young people recorded in more than a decade" (p. 63). If the projection proves to be true, this would signal a substantial decline in church attendance and participation before the close of this decade. Young people need to learn that doing what is right is not always the easy choice, but that it is possible. Youth workers have to note the importance of their calling to work with young people seriously and wisely by redirecting them. As the apostle Paul contemplated on how he changed and where he needed to go in order to bring people to Christ (1 Cor 9:19-23), so too must the leaders and parents decide how best to minister to today's young people.

\section{The Role of the Church}

The church needs vital models that will be essential for its youth. Perhaps it also needs nurturing leaders who will establish relationships that will provide opportunities for youth to see the word lived out in real life. Stevens (1985) asserts, "The church is an extension of the incarnation of Jesus on the earth" (p. 113). This means that the Bantama Church needs to represent Jesus in order to enhance youth ministry and the entire youth participation. To do this, Stevens (1985) suggests further that "it needs to supply an environment that is safe, and where the youth will not feel threatened" (p. 113).

Youth leaders must be committed to consistent involvement that is frequent enough to ensure recognition and continuity. There must not be any cultural barrier to divide the adults from the youth for which would not strengthen their interest in church participation. Ratcliff and Davies (1991) state, "Individuals in the local church tend to be more interested in attracting ever growing numbers of youth rather than genuinely 
transforming those they have into disciples" (p. 261). Instead of developing personal piety, entertainment such as special singing groups and other recreational activities are the principal functions of youth groups.

Youth today are not looking to the church for entertainment. They want a church that will help them develop a vision (Troeltsch, 1932). In contrast, celebration is entirely compatible with socially involved youth ministry. The church is clearly a place to celebrate, as indicated throughout the Scriptures (Ps 150). However, Troeltsch (1932) still believes that celebration is to occur within the context of social concerns, not in a place of activism (p. 261). In my personal concern to preserve the religious aspect of the ministry of young people, the adults must be careful not to dichotomize the sacred and secular too strongly.

Gane (1993) contends that the acceptance of peers has a major role in helping young people establish their own integrity and identity (p. 43). The youth of Bantama Church want to know that they are accepted outside the confines and security of the family of God. It is up to the entire church family to create an environment that will encourage their fellowship and be willing to utilize their spiritual gifts. Robbins (1990) amplifies that a "ministry of nurture" must have arms wide enough to bring the youth into its embrace (p. 179). Many lack a safe place to wrestle with issues, a safe person with whom to be honest and accountable. This leads to hopelessness. The church must be as , an antidote for the safety of the youth.

The youth ministers and the leadership of the Bantama Church may encourage youth participation in church programs and consider what their lives will be like after attending to their requests. The next important stage for the Bantama Church is to 
develop interpersonal relationships among the youth themselves, and perhaps, in the church as a whole. Creasy, Clark, and Rahn state, "Youth ministry should not and cannot be reduced to a pragmatic sideshow of a local congregation. Ministry toward and care for the young people at all levels is a central responsibility of every member of congregation" (2001, p. 27). Though, when given much authority, too loud a voice, and too much autonomy, the adolescent stage can be more harmful than beneficial for a young person, only when it is within the protective embrace of adults or congregation can the growth of the youth be consistent (Clark et al, 2001, p. 29).

\section{Deeper Relationship}

One way church members can build deeper relationships with young people is through a willingness to spend time with them. According to Burns (1991), a "deeper relationship" is the key to effective youth ministry (p. 397). Jesus commands his disciples "to love one another as I have loved you" (John 15:12). Fitzgerald observes that revelation creates friendship rather than presupposes it. To demonstrate this love, Jesus discloses everything to the disciples in spite of the fact that they were unreliable. Stated theologically, this demonstrates grace, love, and the desire to build deeper relationship with them. By treating His disciples as friends, Jesus makes them precisely part of Himself, the essence of cordial relationship He had for them (Fitzgerald, 2000). Aokoi et al. (2000) observe that the church should foster an environment of deeper relationship in which spiritual growth can take place as well. He observed that adolescence is a time of significant developmental changes in which young people pose questions as to their identity and face new pressures that challenge their existing value system. Therefore, even as they seek separation from their parents, young people long for and require adult 
guidance (Fitzgerald, 2000). The church must promote interpersonal relationships as opportunities for young people to meet with adults who live genuine Christian lives and talk on relevant issues. These relationships will provide the encouragement young people need to grow in their Christian commitment. When this is established, young people will also experience a deep love from the adults that closes the gap (Burns and DeVries, 2001, p. 217).

Young people are hungering for this deep and meaningful relationship with God and with adults. Keefauver (1984) states that the youth are not finding their trust and loyalty in those they look up to. They lose heart in church activities and eventually stay away from its programs (p. 10). In response to this problem, the ideas of Keefauver must be taken into deeper consideration. The good news for youth is the inclusive and trusting experience in relationships through Jesus Christ, which is always a guiding principle in their search for better lives. Pamela maintains that the "environment for experiencing God's love or unity" is the church. Young people who are involved in mentoring relationships with positive adult role models are far more likely to make positive impacts (Pamela, 1998, p.12). This indicates that through acceptance and trusting relationships with Christian adults, young people can be drawn into a lasting relationship with Jesus Christ for deeper relationships.

In a national search project commissioned by thirteen denominations and youth organizations, the Search Institute studied the needs of young teenagers. In the research report noted, "Young adolescents, eight hundred fifth-ninth graders responded strongly when asked about needing the relationship of others. Forty-eight percent responded that they worried "very much" or "quite a bit" about "how well other kids like them." Forty- 
five percent were very concerned about "how their friends treat them" (Search Institute, 1984, p. 97). In 1980, Gallup's surveys of unchurched young people indicated a deep yearning for a relationship with other caring fellows and with God. He wrote, "Spiritual nourishment is the highest goal that young people presently need" to build relationships with their peers and adults. Relevance is no longer the code word in the religious quest of youth, but is now spirituality and relationship" (Gallup, Jr. and Poling, 1980, pp. 30-31).

\section{Youth Ministry in a Multiethnic/Multicultural Context}

One of the struggles for the Bantama Church has been in the area of ethnicity and culture. As the church increases in population, many different individuals from a variety of ethnic backgrounds are joining the congregation. Some people feel ignored. Some are not involved in anything more than attending the church services on Sabbath morning. Among those who are involved or wish to be involved, there is some polarization depending on the region one is from, but the barriers are more the result of differing cultural practices. There are differing values across age groups. The result is a church where people go to hear the speaker preach. There is little involvement and interaction.

Habermas and Issler (1992) found out that, "experiencing genuine fellowship through the common bond of Christ can tremendously incite youth into meaningful interpersonal relationships (p. 50). Bantama is a suburb of Kumase, the second largest city in Ghana. It will continue to grow and attract Sabbath keepers, but as the youth ministry moves into the next millennium, it faces the challenge of experiencing and presenting a Jesus who transcends all cultures, races, and communities. Without listening to, learning from, and ministering to one another, the older leaders and members will fail to give the youth an authentic understanding of what it means to belong to Jesus in the 
multiculturally diverse world they are encountering.

\section{Cultural Practices and Beliefs}

Owusu-Kwarteng (2005) indicates that some traditional groups in six of Ghana's ten regions, the Brong Ahafo, Central, Eastern, Northern, Volta, and Western regions have long and close ethnic ties with the Asantes of the Ashanti region. The 2000 Country Population and Housing Census report revealed that almost 20 percent of Ghana's eighteen million residents are located within the region's boundaries, ranking the Asante area as the most populated in the country (Ghana Government Statistical Services, 2002). The Akan ethnic groups to which the Asantes belong comprise over 48 percent of the population of Ghana. However, the unofficial language for commerce and business is Twi, one of the languages of the Akan ethnic groups (Owusu-Kwarteng, 2005, p. 22).

Explaining a summary of the 2006 Bantama Church statistical report to me on the telephone, Elder Kofi Brenya mentioned that about one-third of the youth are multiethnic (Personal communication with church elder, Sept., 2008). He concluded that the domination of the Asante culture in the church has diverted the interest of other ethnic young people from participating in spiritual activities. Sometimes, among the youth themselves, ethnic conflicts arise over dialect. Kyeremateng (1996) points out that the Asantes have less regard for those who speak other dialect, because they consider themselves superior to all other tribes, mainly due to victories in historic wars (p. 67). Hence, there are issues of tribal domination among the youth. Speakers of other dialects have problems expressing their views in their meetings due to its multiethnic context. They are not fluent in Twi and English is not commonly spoken, thus creating an inferiority complex among them. This is where I differ from the views of Owusu- 
Kwarteng on his promotion of the Asante culture. There must be a balance of cultural application since the church is made up of a mixture of languages and cultures. Church leaders need to involve the youth in leadership roles as a means of dealing with church issues. Though it could be a sensitive issue, the youth will be happy to see the adults in their meetings and working together with them. Coleman (1995) observes that the basic values and norms of our culture infuse both youth and adults and that where there is conflict in basic values, the individual person is most likely to follow the values of friends (p. 117). This review demonstrates the challenges and dynamics of the impact of culture, and in Bantama, the Asante culture in particular. It also shows that mutual understanding among youth and adults can be developed.

The issue of traditional "authority," a system of Asante beliefs that has survived over the years, continues to dominate in the Bantama Church. In the Asante (Akan) context, the title "Opayin" or "Nana" translates as an elder. "Barima," "Okogyeasuo," or "Osabarima" or the other titles accorded chiefs who are normally considered as the ethnic leaders are traditionally explained as the head of a group (Nana Owusu-Kwarteng, p. 23). The Asantes highly esteem and make great efforts to preserve their cultural heritage. There is a hierarchical order that places kings, elders, and highly recognized personnel above all others. Lim (1995) noted that parents view family ties, obedient spirit, submission to "elders," and hierarchical order in relationships of utmost importance (p. 2). This cultural practice has become a part of the church, resulting in a practice that requires that elders and pastors be honored as kings and chiefs. In the Asante culture the least most likely to be honored, or even respected, are women, young people, and children. 
Nana Kwaku Wiafe Brobbey Owusu-Kwarteng was a traditional chief in Maase Offinso. He earned his bachelor degree at the University of Ghana, Legon. He later spent some years in the College of Education, Ohio University, where he earned his Ph.D. He returned to Ghana and was appointed as Director General of Ministry of Education. He took it upon himself to work tirelessly with many of the chiefs of Ghana to promote formal education among the young people. Owusu-Kwarteng (2005) argues against the notion that unless one originates from a particular lineage or is an elder of an actual clan, he can not be nominated as an elder. To do that is extremely remote (p.23). He further states, "As society changes and embraces multi-ethnicity and reaches out to all age groups, the churches will more likely transition" (Owusu-Kwarteng, 2005). This change is needed, particularly where youth are concerned. Banks (1981) points out that without each other, the church and its youth are left to their own limited cultural conceptions of what it means to belong to Jesus who is the source of unity in diversity (pp. 109-110). He notes, "Youth must be taught to accept themselves and others with all their strengths and weaknesses, and they need to be helped in breaking down the walls of partition that separate the races" (p. 404). Meanwhile, all participants who contribute, either through spiritual activities of the youth in the church or in the community help the church, society, and community to grow (Bosch, 1991, p. 45).

Church elders need to know that continuous progress of the church in the future depends on the kind of youth being produced today. There is the need to affirm and appreciate those who "increase the sense of self-worth, which in turn precipitates success in all areas of one's life (Kouzes and Posner 2007, p. 286). Myers (1987) argues for the need for youth participation when he challenges leadership to become part of that "youth 
bias" themselves (p. 103). Richards (1985) expands the ideas of Owusu-Kwarteng with the view that "our societies, communities, and even churches are to be reminded that the world is more effective in communicating its way of life than we are communicating God's." Since the creation of man, culture, as a complex of values, beliefs and understanding of life, has been communicated in close interpersonal relationships and shared experiences (p. 51).

Additional research has shown that engaging youth voices is an essential element of effective organizational structure among community and youth-serving organizations (Checkoway \& Schuster, 2003, p. 51). Youth participation is an approach in defining the problem and using the results. In this approach, they do not serve as directors, but partners in any work which is initiated by them or in collaboration with adults, rather than subjects obeying adults who take the lead (www.colorado.edu/journals/cye).

\section{Cultural Influence on Parental Relationships}

Young people have experienced a big cultural gap between themselves and their parents and church leaders due to the hierarchal cultural practices of the Asante. Many of the young people I interviewed regarding the cultural gap gave similar answers. Many of them answered this way, "Most of us are denied freedom of expression and freedom of worship." Others answered, "Pastor we are fed up with the attitude of 'do's and don'ts,"” or "We will let them do everything since they like that" (Interviews with Bantama youth, July 2009). Smith and Denton (2005) call these practices "untold danger" and subsequently suggest that an immediate solution must be provided to deal with them (p. 260). They further direct the problems of the teenagers to religiously active parents and to adults in the congregation to whom they could turn for advice, wisdom, and 
encouragement (p. 69). This study confirms the importance of positive parental relationships with youth, which will likely decrease their tension. It is important for young people to be able to talk about faith with older adults. The cultural gap will close and the youth can relate to the adults in the church and in the homes.

I interviewed a couple of youth leaders in the Bantama Church to find out some of the causes of the decline of youth participation in the church programs. The answers show that both active and non-active youth attend church but for different reasons. One of the top reasons given by youth was the lack of a loving experience with the leaders. Others view the lack of participation in church activities as growing out of a loss of concern for the youth. The non-active respondents say that their peers only show up for Sabbath worship to appease their parents and to keep from being harassed (Interview with Bantama youth, 2009). However, the results indicated that both active and nonactive respondents were close in their views that youth participation in church programs is related to the routine of habit. The interview identified some differences. Active respondents see their participation as something from a younger age as directed by their parents and were afraid not to fulfill the desires of their parents. On other hand, the nonactive respondents did not value their participation as they felt that their participation was forced on them. In the interview, I observed that the most common reason for church attendance was due to parental pressure (Personal Communication, Agyenim-Boateng, 2007). In my view, many of our youth fail to see church involvement as an obligation or responsibility toward God. However, I disagree with their opinion. Black (2003) maintains that those of the youth who do not show up in church programs also lose interest in these activities (p. 36). In addition to attendance at programs, they often sense 
some parental pressure to be more active in the church, but seem to view this as an imposition on their new-found freedom. To overcome these trends, Black (2003) has suggested three stages of family ministry for young people. These three stages are briefly discussed below.

1. Moving teens toward adulthood-Parents must be equipped to understand the transition of their adolescent into adulthood. Parents need help in blessing and freeing them into the world of young adulthood.

2. Parenting style-Parents need help adjusting their parenting style as their adolescent grows towards young adulthood. They need help in the transition of their role from "parent" to "adult" for their maturing adolescents.

3. Spiritual leaders in the home-This is a wake-up call for family ministry. The faithful attendance and spiritual depth of parents is a major factor. We must give practical, in-depth guidance to parents on how to be spiritual leaders to young people ( $\mathrm{p}$. 36).

\section{Major Behavioral Problems and Confrontation}

According to the Statistical Report of the Central Ghana Conference, "The majority of births in the Conference were to young adults in Bantama." Almost threefifths of all young adult women who gave birth in this time frame were from the Bantama Church (C.G.C. of SDA Statistical Report, 2003). Ooms (1981) states that by choosing motherhood over marriage these young women are not necessarily rebelling against or responding to reigning values which strongly discourage early marriage. There is strong commitment to the "values of the church principles as a lifelong goal to the young people." Today's teenagers find it much harder to come up with good reasons to say 
"no" to sex or to avoid those who are not good marriage candidates (p. 9). In his study, Gibson (2000) observes that of all the sexual assaults handled by law enforcement agencies, sixty-seven percent of those crimes are committed against juvenile fold (p. 12). The Bantama Church pastor said that fifteen to twenty thousand Ghanaian youth die of immoral sexual conduct. Many from "Bantama Church has been victims of some type of exploitation every year" (Interview with Bantama Church pastor, December 2008). In other words, a lack of commitment to the moral values upheld by the church is creating a big problem in the resources needed for today and the future.

Despite local programs geared toward stopping these problems, the impact on young people can be severe. They still feel some emotional effect because they are hurt. Another behavioral problem that hinders youth is a fear of failure more than by a desire to succeed. In Erickson's "womb to womb" model of psychological development, adolescence is the period when a person is actively forging his or her identity and seeking to announce who he is with resounding confidence. This time in a young person's life is a struggle between dependence and independence, and others around him often have no warning of when these two needs may conflict (Erickson, 2002, p. 262). As a result, great confrontation is taking place not only between young people and the church leaders, but also with the parents.

The concept of cultural understanding among the parents does not correspond to the formal education the youth go through in schools. It has discouraged the parents and the church leaders from healthy communication with one another. Walsh (1998) indicates that those young people who are able to "talk out" their problems and concerns with their parents are much less likely to "act out" (p. 107). One mechanic who works near the 
Bantama Church once remarked that he would not allow his kids to join such a company of drug addicts and smokers. He grieved over what he sees the youth doing after church meetings. He rarely observes adult supervision. Van Hasselt and Hersen (1987) believe that a teenager at the experimentation level, when exposed to substances that are harmful, will decide to try it. The authors went on to explain the harmful effects of the substances available to youth (p. 390). These observations are not different from what could be said of the challenges youth face as they disassociate themselves from church activities. Adults need to model and to be available. As Richards (1985, p. 33) observes, "It is more important to see the values expressed in their lives than to be told what to do." Some concerned parents of Bantama Church, after realizing the high risk factors with the young people, suggested that not only should the church help the youth deal with behavioral problems, it should also help them with the educational challenges they face (Personal Communication, Boasiako-Antwi, 2008).

\section{Youth Leadership Issues}

Burns (2001) asserts, "The act of leadership is one of the most observed and least understood phenomena on the earth" (p. 2). Burns, furthermore, draws this observation based on his perception of real world politics and players in leading roles over the past century (p. 2). Rost (1991) argues that the very method that scholars in the field of leadership studies use in their approach to the field of leadership confuses a meaningful version of the subject (p. 5). This confusion about leadership as a discipline has been intensified by Stodgill and Bass' (1990) observation of "the endless accumulation of empirical data that has not produced an integrated misunderstanding of leadership" (p. 7).

However, leadership is still an important and exciting field of study and practice 
that needs to be recognized. As Owusu-Kwarteng (2005) notes, "such leadership practices" can count on the positive achievements impacting leaders and their followers with whom they interact on the cultures and situations within which they operate (p. 24).

\section{The Asante Concept of Leadership}

Since leadership takes place in various forms and through many processes, I will look extensively at the Asante traditional leadership and see its impact on some leadership theories. I will also compare the traditional leadership concept of the Asantes to spiritual leadership theories to see how the youth can come in. Burns (2001) notes, "if typical authority is perceived and used as a property, it becomes contrary to youth-driven youth ministry" (p. 24). Though not all young people may have the qualities of leadership, there are varied qualities that some young people can claim in order to be leaders. Young people and adults together can begin to identify the qualities and then work on developing leadership. Fields (1998) adds that "when a church primarily values hype or sees some people as with special gifts and deals with them likewise, then the need for a spiritual leadership becomes little" (p. 5). He makes a further statement that "the secret to developing youth-driven ministry is adult-youth partnerships (p. 39).

Mazrui (2001) illustrates African leadership in types and categories and does not offer any succinct definition, but his approach, nonetheless, offers a closer understanding of leadership as it has been practiced in Africa in the past fifty years. He categorizes leadership according to eight pillars/styles that align with traditional leadership systems (Owusu-Kwarteng, 2005, p. 26). They are (a) quest for aristocratic effect, (b) disciplinarian leader, (c) royal historical identity, (d) patriarchal leader, (e) mobilization leader $(\mathrm{f})$ reconciliation leader $(\mathrm{g})$ housekeeping leader, and $(\mathrm{h})$ personalistic, and 
monarchical tendency leader. These pillars/styles do not assist in interpersonal relationships but only destabilize good efforts of unity (http://igcs.binghamton.edu/). Boahen (1997) agrees with Mazuri on the admiration the Asante give to their kings and how they see them as superior over all entities. An example is the Queen Mother of Ejisu, Nana Yaa Asantewaah, who commanded the last resistant army to encroaching British forces into Asante territory in 1900. Rulers have the right to command and oblige subjects the obligation to obey.

The only solution to the traditional concept of Asantes is participative leadership (Northhouse, 2004, p. 126). Church leaders need to consult with the youth, obtain their ideas and opinions, and integrate their suggestions into the decisions regarding how the group and the specific ministry will proceed. According to Pearce and Conger (2003), the key distinction between shared leadership and traditional leadership is that the influence process involves more than just a downward influence on subordinates by an appointed or elected leader. Rather, leadership is broadly distributed among a set of individuals, instead of centralized in the hands of a single individual who acts in the role of a superior (p. 1).

Edudze (2000) believes that people feel very reluctant to bring youth on board; he also sees it as a cultural problem, because there is the tendency to say that the adult is "always right" and must decide for the younger generation. The danger of being autocratic, authoritarian, and dogmatic in leadership and assuming that role leads to strong reprimanding. The youth are always only followers and not active participants in the decision-making process. Hagberg (2002) phrased this leadership style as "puppets on a string that have to respond directly to any movement of the puppeteer" (p. 5). 
Weems (1999) states that leadership exists on behalf of and for the sake of community and it emerges from different people at different times in different ways ( $p$. $59,60)$. The theory recognizes every person for leadership because God's gift of talents is universal (Eph. 4:5). Kouzes and Posner (1995) state, "Liberate the leader in every one and extraordinary things happen." They emphasize that leaders, because of their position, may need to refer youth issues to the church board, defend possibilities, and show the youth that they move together (p. 21).

\section{Power and Authority in Leadership}

The issue of power and authority was my central concern, especially when I was called to serve as a district pastor of Bantama. Misuse of power and authority had created confrontation between the adults and the young people. In order to remain growing and effective, the church must have within it an important insight of building team work and at the same time must be open to much change. Kouzes and Posner (2007), highlighting leadership authority and power, practically expressed: "Some standard practices, policies, and procedures are critical to productivity and quality assurance, but the success of their usage may also depend upon the area of operation" (p.121). To avoid the status quo, make a list of all practices in your organization that respond to the saying, "That's the way we've always done it around here" and imagine its ineffective results (p. 120). James MacGregor Burns (1979) indicates that leadership, unlike naked powerwielding, is thus inseparable from followers' needs and goals. Such leadership occurs when one person takes the initiative in making contact with others for the purpose of exchanged and valued things. It is only when a leader has less confidence in his organization that he finds it hard to entrust responsibilities to them (p. 42). Ministry that 
includes all levels of people is vital for the church and it calls leaders to delegate their authorities to all classes of people to utilize their talents. Jan Paulsen (2007) said, "This opportunity will prepare the youth not only for the future leadership, but it will also keep them in the church and increase the level of their participation in church programs" (Communication with students, 2007).

\section{Call to Servant Leadership}

Call to leadership is characterized in "one who leads in order to serve, who serves the highest priority needs of others, and who prizes the contributions of each individual to the whole" (Greenleaf, 2001, p, 6). Thus the leader is the servant first. Naturally, there is the feeling of service, and by this choice, one becomes a servant first. The difference lies in the desire to be a leader first, perhaps because of the need to lessen an unusual power drive to acquire material possession. "Leaders who classify themselves as servant leaders lead in such a way for others to desire to become servants" (p. 7).

A lust for power and authority is one of the deadliest sins, because it is often hard to detect and usually cloaked in the "noblest" of motives (French, 2007, p. 21). This clearly shows the principle of servant leadership, where calling, training, and empowering is emphasized. Leadership therefore, is a call to service, and not the responsibility of promoting self (Adams, 2008, pp. 29-33)

\section{Jesus' Example of Leadership}

Youth leadership has followed the trend of a dictatorship found in the beliefs and cultural values of the Asantes who have dominated the church of Bantama. However, as a follower of Christ, a Christian leader takes the role as described by Greenleaf et al. 
(2002) as a "servant first, beginning with the natural feelings that one wants to serve, to serve first" (p. 27). In John 13, it is recorded that Jesus' participated in an act of humility by washing his disciples' feet. In doing so, it became the precursor to the humiliation he was to suffer on the cross. In this manner, Jesus casts His vision of how the disciples should live when he was no longer with them, emphasizing that knowing how to love others is not enough; one will be blessed when love is expressed in service (Kostenberger, 2004).

Leadership is not standing in front of a crowd to speak or command. It is, rather, imitating Christ in attitude and action, presenting Christ to the people in character, words, and actions. Weems (1999) stated that leadership exists on behalf of and for the sake of community and it emerges from different people at different times in different ways (pp. $59,60)$. Jesus' leadership paradigm showed that no cultural barrier could limit how far the call to love one another is extended. Jesus derived His power from God and exercised that power through love. He extended this power to His people along with the best safeguard against abuse the commandment to love one another.

The leader who loves his people lives beyond manipulating or exploiting them. Jesus led people to follow him as he revealed his love and redemptive power to them. Whether the role of leadership is by appointment or election, everyone can play a role. Blackaby \& Blackaby (2001), “everyone experiences leadership” (pp. 3, 4). Jesus' leadership style was the opposite of the scribes, Pharisees and priests. When they wanted to speak with authority, they said, "As Rabbi Hillel taught ..." (p. 4). They referred to a regulation, precept, or teaching by naming a famous predecessor as opposed to the form 
of Jesus' leadership. Jesus' statements of love were contradictory to their common statements (Matthew 5:27-44).

Jesus' style of leadership was based on love, compassion, and faithfulness to others and to God but not on outward behavior. McNeil and Ford (1960) emphasized the relational aspect of Jesus' leadership. They said, "Without knowledge of God there is no knowledge of self (p. 35, 37). Our young people should be guided in their attempt at leadership roles through worship, fasting, prayer, and study of the Scriptures. These are basic essentials to the formation of Jesus' character in our lives (Herrington, 2003).

\section{Discipleship}

"Learn" is manthano, the verb form from which mathetes, "disciple," comes. It means "to learn, be taught by instruction, experience or practice" (Abbott-Smith, 1937, p. 277). It also means "appropriate to oneself either through instruction or practice" (Bauer, Gingrich, \& Danker, 1979, pp. 27-28). In Mark 3:13, the appointments of the twelve disciples whom Jesus chose were to learn of Him. It is more than the simple acquisition of information about Jesus: It has to do with a change of life, a transformed life-style through intimate relationship with Him (Mounce, 1993, p. 47). When we are called to follow Jesus, nothing on earth, however sacred, must be allowed to come between Jesus and the man He has called. Discipleship is a possibility which can only be realized when we determine to surrender to His call (Bonheoffer, 2001, p. 18). Youth must be directed wholly to Christ, looking neither to personal gains nor to the world for fulfillment.

Complete discipleship cannot be accomplished simply by willing it to be done or in our strength. The Holy Spirit equips and helps us to grow in the Lord and know Him better. 
The concept of discipleship must not necessarily involve physical discipline. Youth should be directed, led and guided to be ready for God's business. White (1893) says the following in regard to preparing the youth:

We have an army of youth today who can do much if they are properly directed and encouraged. We want our children to believe the truth. We want them to be blessed of God. We want them to act a part in well-organized plans for helping other youth. Let all be so trained that they may rightly represent the truth, giving the reason of the hope that is within them, and honoring God in any branch of the work where they are qualified to labor. (General Conference Bulletin, 1893, p. 24)

The greatest deficiency of the church is that youth are left on their own to decide their spiritual destiny. According to Mark, the purpose for appointing the twelve disciples was that they might be with him for training, guidance, and commission of the Gospel (Mark 3: 13-14). To be with him means that they will be his disciples or learners, who in his school, would be trained to do his work. The greatest deficiency with the church is that youth are left on their own to decide their spiritual destiny.

\section{Training Youth as Disciples}

Jesus spent three years with the disciples training them for ministry. Effective youth ministry today still requires spending time with youth in their training. The youth are frustrated and will not come to youth fellowship programs unless they have fun because the church has failed to make clear the meaning of the call to discipleship (Ng, 1984). Dietrich Bonheoffer's life was a modern model of training of discipleship. He was a gifted theologian and teacher whose understanding of discipleship led him to act against the Nazis in Germany. Imprisoned for his involvement in a plot to assassinate Hitler, he nevertheless found it possible to write and to witness while in a prison cell. He wrote several books, which called twentieth century young people back to radical Christianity. 
The youth did not call themselves but Jesus called them to discipleship. One of Bonheoffer's most famous points is that discipleship is not cheap grace; it is costly grace (Bonheoffer, 2001).

Discipleship may not lead to a cross or to a martyr's death. However, for young people, as well as others, discipleship does lead to a style of living that requires sacrifice and often suffering. Like the disciples in the time of Christ, young people must be taught to give up some comfort or a circle of belonging in order to be disciples. Each young disciple's sacrifice and suffering will be unique and personal, but the cross will be required, and the church must be honest and helpful in informing young people that being Christian is costly $(\mathrm{Ng}, 1984)$.

\section{Spiritual Formation of Youth}

Spiritual formation is an interpersonal relationship in which one learns how to grow, live and love in the spiritual life. It is primarily a vital union with God, our new creation in Christ, and immersion in the Holy Spirit. A real formation work is "heart work" (McNeal, 2000, p. 30). The disciples spent time watching Jesus in all walks of life. If the young people will seek Christ, He will make their efforts effectual and "place them at a right relation to God" (White, 1890). Young people's focus on spiritual formation as initiated by the church is based on the Bible. This is often manifested in Bible studies, witnessing, and other religious education. Traditionally, youth retreats are developed, presumably to help nurture their relationship with Christ. When youth ministry is at its best, it challenges young people to be rooted in the life and teachings of Jesus Christ. It further states that "ministry is more concerned with soul winning but young people should be won by Christ first" (p. 31). Contemporary young people can then engage in 
any spiritual warfare at the expense of addressing social injustices.

By the saving grace of Christ, young people acquire obedience. They submit themselves to the Word of God to be directed by the Holy Spirit. Arzola (2008) states that "salvation that is manifest in the gift of obedience is confirmed by obedient action" (p. 21). He believes that the necessity to develop their healthy spirituality and respect is a call for all religious traditions. Though every aspect of youth ministry teaches young people something, programs must be purposeful, with a definite time so teens can be taught the Word of God. If youth ministry merely provides activities which entertain young people, though it may be providing the needs at some point, they will miss the opportunity to have an even greater impact (Maxwell, 1993). God wants the young people "to be taught and observe all things whatsoever I have commanded you (Matt 28:20). The lives of young people will be spiritually filled when they are connected with Jesus.

\section{Incarnation of Jesus}

Modernist scholars argue about the authenticity of the birth of Jesus, and thereby deny the theory of incarnation. They hold that Mary the mother of Jesus was not a virgin as presented in Scripture. By rejecting the virgin birth of Christ, they argue that the Hebrew word 'almah (Isaiah 7:14) simply designates an unmarried woman or a young maiden and therefore, deny the reality of the incarnation of Christ (Shedd, 1889, p. 280)

The incarnation itself teaches us that the second Person of the Trinity's coming into the world and assuming a human nature was a reality. By His incarnation, the Son of

God came into a state of humiliation to be part of humanity. Thus the Word became flesh.

The promise of the incarnation of Christ in the Old Testament realizes its 
fulfillment in the coming of Emmanuel, "God with us" (Barth, 1911, p. 38). Thus, Jesus embodied the unreserved presence of God with sinners. The incarnation revealed the solidarity of God with man and of man with God. This was established at the level of actual humanity, not idealized humanity (Anderson, 1979, p. 569). Jesus did not come half way and just appear as man. He was a real man, a fellow traveler, one of us. He knew the frailty of the flesh for He too grew tired and hungry, experienced thirst and knew pain. He truly "mixed it" with humanity (Stevens, 1985, p.143).

\section{Incarnational Model of Youth Mnistry}

Jesus declared that He "did not come to be served but to serve" (Mark 10:45). He introduced a new order when He said that whoever wants to be first must be the slave of all (Mark 10:44). Jesus was not demanding from the followers something foreign to Himself, for as the Incarnate Word He had emptied (ekenisen) Himself and become a (doulos), slave (Phil 2:2-8). John records Jesus' act of servanthood when He took a towel and washed the dirt from filthy feet. In this context of service, He made it clear that if $\mathrm{He}$ the Lord and Master, had washed their feet, they should follow His example, not just in washing each other's feet but serving one another and the world (John 13:13-17; 17:18). A survey of youth ministry literature reveals that there is surprisingly little written about the central feature of the incarnational model of Jesus' ministry and His exhortation to His disciples to be servants. However, this is the model of ministry that Jesus demonstrated in His life. Any ministry in the context of the Christian church must have deep connection with the ministry of Jesus. It simply means the "presence of God" on earth and that is the real goal of the "the Word became flesh and dwelt among us" (John 1:14). Yoder (2009) indicates that young people are desperately looking for safe places to 
release their tensions brought on by the experiences of everyday life (p. 51).

There will be a profound crisis that will deprive the youth from having interest in spiritual matters which may result in death. It is in this context that many believe that "God became man and dwelt among us" (John 1:14) just to redeem youth as well. However, other research shows that between 2000 and 2010, the number of juveniles will increase substantially (Creasy, 2000, p. 85). The secret of effective spirituality of young people is to point them to the cross of Jesus. This is why the incarnational model and visions for youth ministry are so important. Parents will have the chance to touch the young people with their rich experience. By becoming a giver and contributor of life and by sanctifying all of one's life, a person has the potential to become godly, an equal partner of creation and development of the universe (p. 177). Interpreting Deut 11:22, Fitch (2000) associates the righteousness of Christ as a way of learning the ways of God and being influenced by His good deeds (p. 22). Fowler (1991) suggests that educators must arouse interest, draw learners into active participation. They also need tó engage students in activities that allow them to experience God's revelation by modeling Jesus Christ. In doing so, we can scaffold the learning experiences contingent on the individual student's stage of faith (Fowler, 1998, p. 354). Cavalletti (2002) highlights the ideas of Fowler, saying, "A relationship is a true relationship; a covenant is a true covenant when both partners contribute to it" (p. 7). We are to be enhanced by God's love; we are free to respond and in doing so, are empowered to live as people of God, partners in community (Groome, 1988, p. 80). Models of youth ministry play an effective role in the spiritual development of young people. Smith (1996) maintains that initiating attractive models for teens is the foundation of a fruitful ministry (p. 8). In one of his studies, he observed that 
three hundred congregations that have been particularly effective in retaining their youth learned that important models draw young people into the center of a congregational life" (Smith, 1996, p. 13). What does this insight mean to young people at a church if they do not have models to follow in their programs?

In subsequent chapters I will present some basic relevant models that may be of help to the Bantama Seventh-day Adventist youth ministry. This model will help young people to shape and determine their Christ-likeness in character and in ministry. This kind of model will also imprint a strong and everlasting seal on the heart, the life and destiny of the young person for eternity. The heart and mind of the youth would be brought into "conformity with God's ideal of obedience, in faith, in action and love" (Hwan Huh, 2001, p. 43).

\section{Organizing for Growth through the Incarnational Model}

At the beginning of any new institutional ministry, a "'process of organization must take place to enable the program to proceed with clear purpose and direction" (Ortiz, 1997, p. 80). Ward (1998) refers to it as an inevitable result of success. Ward stresses that this institutional ministry process will enhance relationships with other students who may not belong to the same denominational sect. These relationships are essential not only to institutional ministry, but also to a sense of identity and acceptance, which will often be the foundation of their growth (p. 133).

Much of the worship in the church is largely not helpful for young people because it has been shaped by the cultural sensitivities of the generation that currently attends church. In spite of the largeness of the youth church, there is no proper set of organizational structures to woo the young people into fuller participation in their 
spiritual programs and hence, causes their separation. Schultz and Schultz (1987) observed that "they learn the process of applying Christian principles to everyday situations" when they discover that they have been entrusted with responsibilities (p. 19).

Richards (1985) mentioned several organizational structures for youth groups thatare currently popular. The youth elect officers, who, with the youth sponsors, plan activities and programs. The officers' concerns are focused on planning and motivating others for involvement in program activities (p. 285). Adult leaders need to work with them in their nominating committee help them nominate their own leaders and train them. The pastor and church elders should be with them, encouraging them to work harder. It is advisable that entire departments within the church work with the youth to show them their support.

\section{The Administrative Team}

The administrative team is the planning committee that steers the ongoing activities of the young people. This group of youth oversees the youth ministry to assure that overall goals are met although they are a subset of the youth council, they work in collaboration with them. Under the administrative team is the planning committee, who will steer the ongoing activities of youth. They are all composed primarily of youth, some leaders of the church and some parents. A common adage in the Asante tradition states, "Alone, one can only move a bucket, but in togetherness, we can drain rivers" (Asante common adage). Their plans for the youth are not pasted on walls, but they involve themselves in all their programs. Richards (1985) notes that the role of leaders is not primarily to serve as talkers or organizers, but to put words into action. They are models, people who through the power of their own Christian example motivate the youth to be 
dedicated (p. 110). This concept of teamwork as indicated by Weems (1999) will help Christians grow spiritually as they accept one another, in spite of cultural differences (pp. $59,60)$. This means that leadership should not be limited because every person's contribution will mean a lot. White (1930) declared the following:

The cause of God demands the highest powers of the being, and there is urgent need in many fields for young men of literary qualifications. There is need of men who can be trusted to labor in extensive fields that are now white to the harvest. Young men of ordinary ability, who give themselves wholly to God, who are uncorrupted by vice and impurity, will be successful, and will be enabled to do a great work for God. Let young men heed the admonition, and be sober-minded...Young men should have broad ideas, wise plans, that they may make the most of their opportunities, catch the inspiration and courage that animated the apostles (pp. 22, 24).

God has placed higher responsibilities on a Christian leader. This requires a special and specific role in the church. According to Maxwell (1993), "every believer is endowed with a spiritual gift that makes one a potential worker for God" (p. 45). When a leader delegates a responsibility, he needs $t$ make sure it is being carried out. Satan tries all his vices on young people because he is aware of their inexperience. The youth leader should direct the youth to Christ and strengthen their faith.

\section{Summary}

We recognize that, not only is our sense of call basically linked to the mission of God in the world, but also God invites us as Christians to share in His relational care to the world. The sense that there is a parallel between our own activities as leaders, parents, and youth workers has constantly inspired youth workers to be engaged in a ministry that cares for the young people. As we practice our teamwork as parents, leaders, and youth workers, the themes of the life of Christ have repeatedly affected the way we relate to young people. Thus, the theme of the incarnational model in Christ's ministry is 
achieved. We are part of the mission of God which seeks to imitate Christ by being focused on relationships as a means of communication.

The damaged relationship as a result of $\sin$ is recovered (Isa 59:3). God has always been a saving God, healing those with whom He deals. God wants us to bind ourselves to young people. It is this binding that this bond is so important for the young people. Youth ministry is veritably rooted in these truths. God founded the relationship between Christ and humanity through his Spirit a relationship that should close any gap between young people and adults (Gal 3:27-29). God has always been dealing with humanity since he left the heavenly glories to dwell among us. He has kept us in mind from the very beginning; and therefore, youth ministry is to be taken up and involved in dealing with youth. The church may use all kinds of gifts, talents, personality traits, and experiences, but God has called adult leaders to walk alongside the youth and facilitate their involvement in fulfilling the plan God has for them. 


\section{CHAPTER 4}

\section{INCARNATIONAL MODEL OF YOUTH MINISTRY FOR THE BANTAMA SEVENTH-DAY ADVENTIST CHURCH}

\section{Introduction}

This chapter describes an incarnational model that may call for implementation in the Bantama Seventh-day Adventist Church. To understand this model better, selective studies on Jesus ministry, based on Gospels, are made. This chapter will describe the Bantama Church leaders' understanding of youth participation and involvement in leadership and church activities. The need for the church to recognize the potential of young people and reorganize them for service to God and man will be identified.

\section{An Incarnational Model for Youth Ministry}

Robbins contends that understanding youth culture is a passport to get people in and out of such a culture. Jesus was incarnated to reach humans. "This movement into our world as a human-who lived in a specific culture, as a member of a specific ethnic group, who supported Himself in the carpentry trade-gave Jesus the distinct advantage of fully comprehending what it meant to be human (Robbins, 2004, p. 262). Successful mentorship of teenagers demands that youth ministers understand that it is virtually impossible to evangelize in a cultural vacuum. Nobody has been able to come up with a gospel reduced to a few culture-free axioms, which are universally intelligible (Robbins, 2004 , p. 247). Even though the incarnation of Christ goes far beyond the wildest scope of 
human imagination, yet it is possible to glean some principles from Jesus' earthly life that can be applied to youth ministry. Just as.Jesus took on Himself the form of a human being, we must take on the "form" of a young people. The central fact of the incarnation is that while we were yet sinners, Christ died for us (Rom 5:8). According to Stott (1992 p. 349). "We cannot stand aloof from those to whom we speak the gospel, or ignore the situation, their context.

Being incarnational does not merely involve some intellectual identification with young people. It requires us to physically be with them. This will require us to go to the places they frequent, such as rollerblading rinks, movie theatres, bars, clubs, small group sessions, shopping mall. We are to go out into the "highways and byways" (Luke 14:23) and become "friends to sinners" Luke 7:34). We are to go to them when average age for puberty stands at 12-18 years (Letham, 1988, pp 333-335). Telephone interviews with some young people from Bantama Church indicate some obstacles to youth participation in the church due to cultural gaps. Comments referred to refusals for them to join the adults in programs; the adults are not caring and unmindful of their programs in spite of their growth. (For expanded comments, see transcriptions of the interviews in the appendices.) The chapter focuses on Jesus' answer to a Youth Ministry in crisis as demonstrated in His incarnational model.

The Incarnational Model is simply the way through which "humanity understands God and His ministry (Kettler \& Speiddel, 2001, p. 52). Pete Ward stated that Christian youth workers should be bilingual, skillfully maneuvering in both cultures (Ward, 1999, p. 80). As the church tries to carry its own mission successfully, it follows Jesus' perfect Model for ministry which was the sample of all ministries. The new model was to be 
followed by the disciples and the church in all generations. A church that emphasizes the incarnational model for Youth Ministry has the best future for youth in mind because it touches the hearts of the young people. To understand the incarnational mode better, a careful examination of Jesus' ministry, based on the Gospel, is made. There are three principles that will promote effective ministry to the young people: 1) Presence in Christ's life, 2) Jesus with individuals, and 3) Jesus among the religious groups.

\section{Presence-In Christ's Life}

Jesus spelled out God's plan of recovery in person. He was God's Gift to bring about reconciliation and forgiveness. He was not only a real human, but a follower, traveler, one of us. He spent the greater portion of His earthly life as a peasant carpenter. Sensing all human emotion, knowing love and experiencing rejection, He showed an authentic love and interest in all people (Gane, 1997, pp. 51, 52). White (1942) comments on the important aspects of the methods of Christ's ministry: "The Savior mingled with men as one who desired their good. He showed his sympathy for them, ministered to their needs, and won their confidence. Then He bid them to 'Follow Me'" (p. 143).

Jesus met people in their environments, in public streets, and private houses, by the sea, and in the synagogue, in boats, and at wedding feasts. He showed interest in their secular as well as their spiritual lives. He was sympathetic to and concerned about their health as well as their welfare, both then and for eternity. Through Him, they witnessed the presence of God, and then recognized him as their Father. Thomas Torrace, a noted theologian, states that it is His life and ministry that became the paradigm for the ministry of the church (White, 1905, p. 725). Jesus did not come to the earth as an angel of glory; neither did He come just pretending to be a human, but as a man He lived among men 
(Matt 4: 23). He also walked among men as Ellen White (1942) claimed: "In flesh and blood, he dwelt with us and was acquainted with our trials, and sympathizes with our griefs" (p. 914). The Incarnational Model is another way of recognizing that every human being is somebody. Though he was God, his presence was evidenced in his service for mankind.

\section{Jesus wth Individuals}

The background of the Gospel of Mark is sensitive to the fact that almost everything has to do with the issue of Jesus' relationships with individuals. He is met by a man with an unclean spirit. From there, Jesus went to the house of a dead girl. While on the way, He was touched by a woman with a flow of blood (Matt 5:25). Although the Old Testament laws forbid any unclean touch (Lev 19:19-27), Jesus showed His ultimate care to her by his personal presence in their lives. Furthermore, Jesus exhibited typically human and personal responses to situations in which He found Himself. He was moved with compassion at the plight of a leper and reached out His hand to touch him (Mark 1:41). Jesus' personal presence in individual's lives indicates His "recognition of humanity" (White, 1942, p. 147).

No leadership trait is commendable if it does not lead its followers to a positive goal. The goal can be achieved through the demonstration of humility in service. Hopkins, McBride, Tyner, Drumm, \& Kannesburg (2009) found that "when youth become involved in service, it changes their lives" (pp. 16-19). They become "humble, serviceable, and willing to cooperate in healthy relationships" (pp. 16-19). In a Harvard Education Letter, former Senator John Glenn (2001) chairman of the Commission of Learning revealed that more than eighty percent of schools with active service-learning 
programs report that a majority of participating students improve their grade point averages. Senator Glenn (2001) additionally states, "A study of a Springfield, Massachusetts, found high school dropout rate push from 1 percent after service-learning was incorporated into the curriculum. The number of students going on to college increased by twenty-two percent, and those achieving grade point of 3.0 or higher jumped from twelve to forty percent." Jesus' presence with individuals shows his higher feelings for their salvation. Campolo (1984) said, "Young people are not going to be attracted to a church that tries to entertain them, but they will be attracted to a church that calls them to a ministry with individuals" (p. 72). A lust for power and authority prevents humility and is deadliest sin. Jesus' power was for the welfare of humanity.

Jesus spent time in personal dialogue with individuals, like the woman at the well. After this, she was engaged in service for Jesus (John 4). What Jesus taught and demonstrated about His personal involvement in people's individual lives builds interpersonal relationship with the youth. Bogart (1996) maintains that "the power of sacrifice and love are best learnt through touching lives of individuals" (p. 63).

Youth are therefore to be encouraged to tell stories of their faith to their personal friends as they mingle with one another. Effective ministry with youth, however, begins when an adult leader finds a comfortable ways of entering into the life and world of an adolescent (Senter, 1987). If the church closely observes the ministry of Jesus, personal relationships will be at the core of their strategy. Whether he was confronting the Samaritan woman at the well on a hot afternoon (John 4), talking with the Pharisee Nicodemus at night (John 3), or praying with his closest followers (John 17), Jesus modeled a loving relational style of ministry (Atkinson, 1997, p. 108). 
Jesus among Religious Groups

Three times a year the Jews were required to assemble at Jerusalem for religious purposes (John 7:1-15). Jesus entered the court of the temple in the presence of the multitude. He demonstrated that being present among the religious group was a sign of their acceptance in his ministry (White, 1942, p. 206). If religious educators are going to impact teenagers with the gospel of Christ, they must work hard to enter into their groups and promote trust in them. This aspect of youth ministry is what many youth workers call "contacting" (Robbins, 1990, p. 180). Atkinson (1997) asserts that "the dimension of being involved in the youth activities does not come without the effort of many adult. volunteers" (p. 109). The church will find, however, that if they genuinely and honestly attempt to enter into the lives of the adolescents, there will be those youth who will respond and be involved in their activities. Atkinson further states that "the church is a safe place where the young people can find significant adult friends who will listen, support, and help them develop their skills" (Atkinson, 1997, p. 191). The church can provide a good foundation for faith formation and point young people to healing and wholeness.

\section{Modeling the Presence of Christ}

When we speak of incarnational Christianity, it is much more than just a certain style of life; it is, rather, something which is exemplified in the life of Jesus" (Hiebert, 1995, pp. 591, 592). John records Jesus' act of servanthood when he took a towel and washed the dirt from their filthy feet. In this context of service and humility, he clearly demonstrated acceptance and involvement as his example of love for all (John 13:13-17). Church members take interest in the youth. They should shake hands with them and 
manifest a kindly interest in their welfare. This is genuine ministry, "a ministry that God approves and that lifts up before the one who ministers, as well as before the one ministered unto, a standard against the enemy" (White, 1930, p. 250).

The ideal functions of the incarnational model should be one that the church must uphold, one that Jesus lived for. Jesus forgot the prerogatives of adulthood and became identified with us. By becoming like one of us, Jesus clarifies the possibilities of the church to work with and for the youth. It is in so doing that the church will feel their hurts, know their minds, and predict, to a certain degree, what they will think, feel, and do. Dettoni (1993) says, "It is enfleshing Christ to youth, showing in our very being what Christ continually shows to us of himself' (p. 22). It is not expedient for the church to judge the youth by their external appearances but to accept them as they are without exception. Like Christ did when he was on earth, so the church can do for youth of today be their advocate and guide.

\section{The Church's Understanding of Youth Ministry}

The youth of Bantama Church form a major portion of the youth in the Central Ghana Conference of Seventh-day Adventists. The number of youth in the Bantama Church is startling and the Conference counts on them for their external programs. A telephone interview with some of the youth in Bantama Church showed a tremendous increase of the youth membership in the church in 2004. According to the data, the main reason for the increase was the public entertainment by the youth. This was characterized in parades during public festivals, at burial services, and other social activities. The church needs a critical objective for Youth Ministry (Interview with Youth, 2008). There is a real challenge as to how young people can be directed for their calling. 
The church understanding of Youth Ministry for nkwadaa, meaning children, has denied them of their potential. The introduction of adults to oversee all programs of the youth means they cannot exercise their rights. Young people are not necessarily leaving the church at this time but they do not show up in the activities of the church. Barry Gane (1997) says, "In any church where there is an active Youth Ministry and young people are involved in programs, they tend to remain active in the church." He further emphasizes that "many churches have a high percentage of losses of the youth because they are left out of the spiritual foundation" (p. 48). The youth claim that little is happening in the Bantama Church because the interests of the youth are marginalized or their zeal to participate is discouraged (Interview with youth, 2009). The belief of the church of the past where good youth ministry was often seen as program- oriented, rallies, events and other elaborately orchestrated gatherings has failed. The youth have not benefitted from them. Burns \& DeVries (2001) mentions, "Long term influence with lasting impact on the lives of the youth comes from people and not programs" (p. 18). One youth ministry expert has said, "The part of ministry that will change the lives of the young people we work with will not be what culture guesses but the voice of Scripture" (Unknown). It is by opening the door of grace for all and charging the youth for commitment that inspires them. According to Cosby (1989), Jesus built enduring friendships as he shared trust and belief in people by his open and caring spirit (p. 160).

The following model will suggest what the church may need to do to change their notions concerning the youth. They should probably be encouraged to accept this model for a successful youth ministry that encourages relationships and participation. White (1925) says, "The church is God's appointed agency for the salvation of men. It was 
organized for service, and its mission is to carry the gospel to the world" (p. 9). The youth have an active role to play in this mission.

\section{Involving Youth in Service for God}

Providing chances for the youth in service is an important opportunity to engage them in active service for God. It creates a way to channel their intellect and ambition in a productive manner. Ortiz (1997) asserts that involving youth is the heart of a healthy and growing ministry. If a healthy, committed, and long-lasting youth ministry is envisioned, it depends on youth being committed and highly involved (p. 73). In a town hall meeting at Elkhart, Indiana, President Barak Obama (Feb 10, 2009) said, "Wisdom is not invested in only a man's mind. Everyone is called to fully participate in bringing America back on track, for people are judged by results" (Obama, 2009). These wise remarks of involvement and participation can virtually heighten commitments. In the Ghana government's attempt to involve young people as part of a decision-making process, Bishop Dela remarked,

I would describe President Mills' nomination of several competent young gentlemen and ladies into his new National Democratic Congress Government as hope for the youth. How many times have we not heard youth groups appealed for the inclusion of the youth in the governance of Ghana? How many times have we not heard Ghanaian politicians promised that they would make the youth the centerpiece of their development policies and include the youth in important decision-making processes of Ghana? How much did we see our politicians deliver on this promise until recently when President Mills courageously nominated several hardworking and talented young men and women to high-profile political offices to help in the development of our nation? (Dela, 2009. p. 1).

This is a novelty because in the past no one from among the community of youth was ever appointed to top political offices.

A study conducted by Dudley \& Gillespie (1992) shows that most of the youth 
who attend church regularly but do not participate in its activities may lose interest in the church (p. 112). The study also confirms that "there is no substitute for actual planning for involvement in the life and worship of the church." The church needs to be much more intentional in involving youth in their functions (p. 112). This is the only way the youth will be encouraged to stay in the church and contribute their quota. Richards (1985) says that it is important that we make our young people aware of a need and involve them as persons in fulfilling that need, helping them interpret the experiences involvement bring and guiding them to discover, in servant ministry, who they are as Christians (p. 260). They are to be shown what the future holds for them. Dela (2009, p. 1) commends the approach of Ghanaians and excitedly said, "We must rather applaud it and encourage more young people to aspire to occupy positions that would allow them to directly affect national policies" (p. 142). Wong (1997), in his summary of the entire concept of involvement of youth declares, "It is necessary to permit the youth to participate in the church administration, by listening to their opinions" (pp. 7, 8).

The prophet Joel emphasizes the clarity about God's investing various gifts on youth. His intention is for them to work in the end time. The church should be seeking these gifts in the young people and use them for work (Joel 2: 28-30). It is, therefore, essential that the Bantama S.D.A. church consider the church as a training ground. They should be mindful that the youth are their future leaders and should therefore recognize them as valuable resources. The Apostle Paul's helpful advice to the church of Ephesus can transform our perspectives and ministries towards the youth (Eph 4:11-13). As a balanced program is initiated, the youth will feel the urge to be involved in all the functions of the church and become part of it. Borthwick (1988) emphasizes the need to 
teach them, exemplify Christian lifestyle, and pray for them so that as members of the body of Christ, they can do their ministry (p. 56). Jesus took another step by involving people He healed, as in the case of the man born blind. He asked him to "go and wash in the pool" (John 9:7), making him a participant in ministry in the process of healing. Though there is no evidence to show he was a youth, yet the principle is clear. Jesus' call to "whoever" has no limit (John 3:16).

\section{Empowering the Young People}

Gradually the Bantama Church has understood the principles of the Incarnational Model, and are carefully empowering the youth. Empowering is equally important in any society that expects to have a warm and inviting ministry. Pyatt (1982) says, "Youth empowerment is the unique form of ministry which says that young people are capable of being leaders, planners, and decision makers" (p. 12). It activates the well-worn phrase that tells us that youth are not only the future of the church, they are the church today (Pyatt, 1982). When youth are empowered, the church indicates her trust in them, recognizing the need to hear their voices. Creasy and Ron Foster (1998) said, "What is needed more than gung-ho adults are Godbearing adults, people whose own yes to God has transformed them into messengers of the gospel" (pp. 52, 91).

We gather people for God so that He can give them what we cannot afford to which is the spirit that empowers ministry. Burns cautions the intensity with which some leaders are self-dependent. He says, "It is their capacity to learn from others and from the environment - the capacity to learn and empower" that will make them good workers (Burns, 1979, p. 116). To make this concept a reality, they need opportunity to 
experience leadership in their own youth groups, in their local churches, and in local structures.

The Influence of Youth Ministry on Church Growth

Many churches seem to believe that God can only use adults in ministry. In most churches, there is very little for the young people to do in the area of Christian service. Many churches only provide their youth with a small section of their master church plan to operate. Others do not find the relevance of allocating operational budget for the youth in their annual budget plan because they are not significantly recognized. "God entirely sees in a different perspective from the claims of man. He sees the youth as believers with the same potentials for service as adults" (Maxwell, 1993, p. 40). Since the activities of the youth are equally important, it calls for the church to consider them as people who are partners in progress.

In 1988, a major survey was conducted of five hundred fifty-three families in twenty rapidly growing churches in North America. The aim of the survey was to determine whether youth ministry was a major contributory factor in the growth of these churches (Roehkepartin, 1990, pp. 17, 18). In the survey, eighty percent responded that youth ministry in the church was a contributing factor towards their decision to join the church. The survey also revealed that twenty percent of the people who had been members for only one year joined the church because of its youth ministry activities. (p. 14). Roehkepartin (1990) claims, "Almost all newcomers say youth ministry was 'very important' or 'somewhat important' in their decision to join the church. While others say that they would have it difficult to join the church had it not been the activities of the youth (p. 8). It is obvious that the church may be able to accomplish all their goals for a 
time, but chances are that splendid results may have been achieved if the youth had had a greater role to play. In seeking to understand why youth ministry was viewed with such importance, Roehkepartin discovered the following factors: families want their children to be comfortable and accepted, and youth ministry helped to make this happen (p. 8). Steve Case (1993) talked to a number of pastors and emphasized on the value of the youth and the danger their absence will cost the church in the future.

Many young people prove that their participation in church activities do not only enhance growth, but establish it. Parents are therefore, concerned about peer pressure and hence, look for an environment where their teenagers will have positive relationships (Burns \& DeVries, 2001, p. 112). When teenagers get excited about the church, they tell their parents and friends how the Word of God is motivating their spirituality. They embark on friendship evangelism which becomes a key means of leading their friends into the church. Roehkepartin (1990) concludes that a strong youth ministry is vital to making a strong stability in the church, and which enhances the growth of the church. Culture should not be seen as a boundary to destabilize the efforts of the young people. It should create a sort of interpersonal link between the adults and the youth so they can serve freely. Stevens (1985) says, "Our relationships with the youth should be mediated by Christ. He is the bond of friendship that exists between people. Parents should not shut the young people off, but listen sympathetically to them" (p. 126). Yaconelli (2008) says, "Only those youth workers who are mystics and possess a lived-out experience of the indwelling Christ will have something spectacular to offer other students" (p. 4). The importance of youth ministry is very keenly felt by some families, who have loved its vibrancy and encouraged their children's participation. Churches would do well to pay 
close attention to the growth experience in the youth's lives, and to the religious experiences which often change the course of their lives.

In his General Youth Conference welcome address, Samuel Koranteng-Pipim mentioned that "a strong and viable youth ministry is not a luxury and sugar-coated form of entertainment but feeding the youth's intellect with spiritual food" (Koranteng-Pipim, 2006). According to Gant (2008), "Students need preparation modeled. This is where their walk with God and openness to the transforming love of Christ begins; it begins with you, as their servant leader, modeling a life of holiness and humbleness" (p. 13). Youth want to know how to do it better. The church has to set up regular training opportunities for the youth and provide them with leadership skills. This implies that youth ministry in the church should be biblically based and mission driven. This will be a tremendous step for their growth as they participate fully and win more of their peers for Christ.

\section{Christ's Example of Servant Leadership}

According to Greenleaf (2001), "The servant-leader is servant first. . When one is a leader, his disposition causes one to be seen as servant first" (pp. 27, 31). This model of servant leadership was another aspect of Jesus' ministry on earth that He left as an example. "And whosoever of you desires to be first shall be servant of all" (Mark 10:44). For the Christian, leadership should possibly assume the role of servanthood as demonstrated in the life and ministry of Jesus. In servant leadership, everyone is a leader (Greenleaf, 2001). It means we all exert an influence to a certain degree, so we all lead. However, the servant leader gives service to others willingly. The leader's service sets him apart as one who is committed to the spiritual welfare and the leading to salvation in 
the Lord. Jesus came to serve others as well as to lead them. The apostle Paul describes this as "taking the form of servant" (Phil 2:7). The greatest example of Jesus' service and leadership of Jesus is recorded in John 13:12-18. This was an illustration of humility and leadership. White writes, "The whole life of Christ had been a life of unselfish attitude. He was not to be ministered to, but to minister (Matt 20:28) had been the lesson of His every act"'(1898, p. 642).

\section{Self-Gratification}

The disciples refused to serve one another because of power, authority and greatness that perplexed them on several occasions. They had understood authority that came from those with power to command and be served. White (1942) further commented that loving service and true humility constitute greatness (p. 103). According to Black (1991), the purpose of leadership is not to lord it over others. It is a new outlook on life that views power from a base of love rather than position (p. 22). Church leaders should not turn against youth because of their age. The needs of the youth are identified by the church and are met at whatever level they are expressed (Ortiz, 1997).

Black (1991) further asserts, "This leadership is symbolized best by the towel and wash basin rather than symbols of rank and wealth (p. 22). One of Jesus' last acts on the earth "was to gird Himself as a servant, and perform a servant's part" (Black, 1991, p. 378). Jesus denounced the idea of authoritarian leadership in Christian environments. He acknowledged the differences that manifested themselves against servants. He was conscious that other people's highest priority needs were being served first. 


\section{Youth Ministry}

The church needs to recognize that young people are their assets. They have to deal with them with respect, honor, and integrity. I have a twenty-year-old daughter. She related well with my wife and me until we recently noticed a negative attitude. The means used to set the differences right was so authoritative that it rather worsened matters. Change in her lifestyle could be possible as she observed our new way of relating to her. We sit together at the dining table and discuss issues, make jokes, and do everything together. As a result, she expresses her ideas and contributes in any family meeting. It is only when we mingle with young people that we can share our experiences with them.

The basic reason of my sole interest in the incarnational model is its relational aspect. It is well working with Bantama Church now. The church has the chance to encourage and promote the development of the youth through the model. This is especially accomplished through balanced programming which meets their needs. McDowell (2000) states, "there must be a daily recognition that all strength comes from the power of the Holy Spirit" if there should be a successful youth ministry (p. 70). If the church intends to see the youth in action for Christ, they must walk with them and give them a voice. The church must consider participation with the youth as an opportunity to encourage and foster their growth. Black (1991) expresses that "Christian leadership means being bound to God in service and love; and willing to serve as he sees fit" (p. 21). A church will never have a strong youth ministry until there are adults who love to nurture the youth. Jesus emphasizes service to the youth as fundamental characteristics of ministry (Black, 1991, p. 83). Black further explains that "this service is expressed in 
loving ways to believers and unbelievers in order to convey the message of God's love to the world (Black, 1991). Though the youth "cannot relieve the physical maladies, they can bring their friends to Jesus who will save them" (White, 1958, p. 351). God's call to the youth must not be obstructed by cultural barriers. If well it is well understood, it produces fulfilling emotional, psychological, and spiritual rewards for everyone. Greenleaf says, "It is not the individual's choice to be a leader or will become a leader, but the community places him in that particular role. The youth might be ordinary people but through the needs of the community, they can emerge as special people" (1977, p. 34).

The youth need to take such responsibilities. As long as they are spectators, they will never fully grow into lifelong servants of Christ (Burns \& DeVries, 2001, p. 13). If a youth worker does not have enough diligence to be a self-starter, it is quite possible that there will be no start at all (Robbins, 1990, p. 24). Every successful leader values training and support. They are equipped for ministry. Gane (1993) says that servant leadership in youth ministry will always be the challenge of youth to reveal Christ (p. 116). It will empower young people to grow into his likeness, and to go out and continue His ministry as servants of both God and the world. The youth are equally called to Christian life and service. Serving is not popular because it is exacting and hard to attain. However, if the youth are willing to give their talents in service, it is highly rewarding and fulfilling when done well (Greenleaf, 1977, p. 37). Once fully equipped for ministry, they become "living epistles" (2 Cor 3:2). Describing the lowliness of Jesus, Paul uses a critical word, "equality" harpagmos, in regard to his equality in relation to God. The term is accurately and effectively rendered in NRVS as "something to be exploited" (Phil 2:6). Jesus did not 
count being equal with God as something to be exploited. A pioneering marine biologist, Rachel Carson (1998), comments on the text by saying, "The human race is challenged more than ever before to demonstrate our mastery, not over nature but of ourselves" (p. 122).

\section{In Christ's Life}

The church needs to view teenagers exactly as God does. They were created for life and not for death. It is part of Jesus' desire that the young people will need the experience of redemption in order to choose life. It was not enough for Jesus to be compassionate with people. Ortiz (1997) claims that for a comprehensive injury, "only an absolute restoration would suffice and Jesus provided that" (p. 66). A sincere love and sympathetic understanding of youth is a big step toward preparation for the youth in their ministry. Ferguson (1968) summarizes this idea when he relates God's consciousness of His struggling children with a compassionate heart for them (p. 37). Jesus was aware of the helplessness of fallen man and He came to meet it: "Be not afraid, for behold, I bring you a good tiding which will come to the entire world; for to you is born this day in the city of David, a Savior who is Christ the Lord" (Luke 2:1). Ferguson (1968) further indicates that this is the import of Christ's coming, part of the meaning of the incarnation (p. 37). The ministry of Christ was all about the love of God manifested through him for the entire world. Jesus seeks for the hurting soul and demonstrates his power of love.

O'Collins (2007) clarifies about this compassion: "Only the personal presence of the Son of God among us could have brought salvation" (pp. 81, 246). Similarly to O'Collins, McIver (2000) clearly expresses it in this way, "Jesus in the fourth Gospel confronts us with his extraordinary and his claims on our lives" (p. 305). 


\section{Holistic Care}

The church should view teenagers as God's handiwork. Jesus desires that young people will experience total redemption through Him. Ferguson (1968) notes, "God does not leave the young people to struggle alone, but He cares for their ultimate salvation" (p. 37). Jesus was aware of their helplessness, and He came to meet it. In His ministry Christ gave His entire life for the sake of the world which includes the youth. This love was not in part, which some church leaders fail to demonstrate to the youth in their churches. Anderson (2001) articulates God's agenda with Jesus caring and seeking the entire youth force (p. 63). The continuous demonstration of compassion as observed in Christ's ministry was because of hurting soul (Mark 8:2). O'Collins (2007) says, "The situation of fallen man was so desperate that only the personal presence of the Son of God among us could have been the solution" (p. 81). McIver (2000) agrees with the statement of O'Collins when says, "His sympathy and love was for everyone" (p. 305). Salvation is not limited to race, color, gender, ethnicity, religion or age. When youth are well cared for, chances are that they will enthusiastically do their honest part in ministry.

\section{Experiencing Discipleship}

From the earliest days of the church, believers in Christ "went throughout the country, preaching the good news of the message" of the gospel (Acts 8:4). Each new company of believers established by the early apostles became "a sort of sounding board from that the Word of the Lord has rung out" (1 Thess 1:8). Paul's awareness which God had in Jesus "reconciled us to himself" was accompanied by a deep conviction that this same God had made him—and us-“agents of reconciliation" (1 Cor 5:18). Richards (1981) observes this as the "central meaning of the Christian's life experience of sharing 
Jesus Christ with others (p. 243). He further states that young people are aware that witnessing is expected, not only of professional Christian workers and adults, but also of them (p. 243). Unfortunately, young people, for a variety of reasons, have lost enthusiasm. A study conducted by Richards showed that young people's failure to participate in ministry is fear, lack of know-how, and lack of relationships.

In Mark's Gospel, Jesus begins calling His disciples as soon as He embarks on his personal ministry. Stevens (1985) reveals that Jesus' reason for gathering the disciples to Himself was that they might learn to minister to people (p. 25). This is the essence of discipleship. Jesus finds people at their work and challenges them to leave everything and follow Him (John 1:35-51). White (1958) indicates, "In order that the work may go forward in all its branches, God calls for youthful vigor, zeal, and courage" (p. 67). Jesus' act of calling disciples has profound implications that are commonly overlooked (Milavec, 1982, p. 108).

McDowell (2000) describes discipleship as "one maturing believer reproducing other maturing believers to the degree that they are also able to reproduce maturing believers" (p. 15). The privilege of orienting the youth can be a tremendous base to equip them for effective ministry. E. G. White (1958) notes that discipleship is the call to declare what one has seen and heard of Jesus Christ. Their office is the most important to which human beings have ever been called, and is second to only that of Christ Himself. (White, 1958). Regardless of denomination and tradition, mission is often cited as the basic reason for youth ministry (Senter, 1987, p. 80). Jesus' model of discipleship is the structure for the highest level. The call of youth into discipleship must be a top priority in the church. Part of the meaning of being a Christian is found in identifying ourselves with 
Christ's great purpose to bring people into a relationship with God. I will address some of the obstacles such as fear, know-how, and lack of relationships which have become impediments to youth involvement.

\section{Fear}

Fear has kept most of the young people from discipleship. In 2002, about fortyfive percent of the youth in the Bantama Church refused to be part of the witnessing team. About twenty percent of those who joined the team were not punctual. Lawrence (1985) identified some of the causes of these fears. He mentioned "potential ridicule, fear of making a fool of oneself and uncertainty about what to say" (p. 245). As these setbacks of the youth are known, the church must make it a priority to deal with them. The New Testament's most powerful example of leadership was to encourage the adults to mingle with the youth to give them directions so they could be free from fear. (1Tim 1:7). Knowing the power of the peer group and the need to belong, we can be sympathetic with such doubts and fears and help them overcome. Alexandra Sampaio (2008) says, "Those who are able to overcome fear of the unknown and the fear of someone else's evaluation are the ones who have truly surrendered themselves to divine guidance, they are the ones who allow the Holy Spirit to use them (p. 7). Sampaio (2008) further encourages youth to stop criticizing themselves and think about the good the message will bring to others ( $p$. 7). The purpose of the church must be to assist youth in their everyday venture of making disciples. When the Bantama Church comes to this realization, there will be a paradigm shift in the view of youth ministry. The youth will be seen as people who can also advance the cause of the church. Spader and Clem (2007) claim, "As the youth move through the discipling process, they not only have an impact on other peers, but they also 
learn the skills and priorities of being a lifelong follower of Christ"' (p. 25).

\section{Know-How}

Some youth ministry experts believe the one primary objective of the youth leader is to care about the level of ignorance of the youth about witnessing. The youth do not care about how much they know until they see how somebody cares for them (Unknown). Lawrence (May, 2008) observes that many youth leaders and youth have moved away from the shepherd model to the general manager model. They are tied up with administrative niceties and perplexities and have little time for the youth (p. 26). Their weaknesses, ignorance, and errors were opened before him, yet he was not discouraged by the purpose of the calling. Burns and DeVries (2001) claim, "When God looks at this generation, what He sees is a generation with hope and a future (p. 42). This is discipleship that lives the Christian life in the context of relationship with another person. This sets a requirement for the church to consider the relevance of investing ample time to equip, nurture, and mentor the youth for discipleship and personal ministry. One philosopher of education has said that people should be involved in situations where they need to use it. He further says that there must "be a ministry to do a ministry" (Unknown). In my view, knowledge and transformation will take place concurrently when there is involvement.

Our churches must promote training classes that provide techniques before the youth engage in witnessing. Ellen G. White (1942) says, the young people should realize that though all the advantages of learning may be within their reach, they may yet fail obtaining that education which will lead them for work in some parts of the Lord's vineyard. They cannot engage in God's service without the requisite qualifications of 
intelligent piety. God has called for action in his noble work, and fitted to bear responsibilities. (pp. 21, 42). The concept of educational training must also be a channel of preparing the youth for ministry.

\section{Lack of Relationship}

Understanding the war the youth are experiencing begins with an understanding of teenage lostness. If there is one word other than lost to describe young people, it would be the word lonely. They are desperately lonely people (McDowell, 2000, p. 4). He further discovers a rescue plan in Jesus' style. It requires courage to leave our comfort zone and plunge into the surf and the storm as Jesus did (p. 3). Tony Campolo (2000) distinguishes the Greeks' philosophy of love where emphasis of love was placed on intrinsic value, some inner worth. He observes, "God does not love us because we are valuable" (p. 75). If Bantama Church would love the youth like Jesus, they must be willing to begin seeing the youth as people who are sacred. Then the ultimate "mark of the youth minister is not what he/she brings to the youth group but the ability to understand that each of the youth is important" (McDowell, 2000, p. 5). If the church ever is to have a positive influence on young people, it must build genuine connections with the youth. George Barna, in his report of third millennium teens, says, "From the standpoint of those who wish to minister to and with young teenagers, breaking down relational barriers and thereby gaining access and credibility will be imperatives" (Barna, 1999). Between January 2005 and December 2005, there were approximately 250 new members added to the Bantama Church. Most of the new members were young people between the ages of 20 and 22 . However, during the same period, over fifty percent of those who left the church were young people. From a telephone conversation I had with 
the church pastor, I learnt that they left because they did not feel that they had the freedom of expression and they felt that no one cared whether they were present or not. They stated that no one shook hands with them. No one welcomed them to church services. In fact, they claimed that some of the members harassed them. One such situation involved the need for the elders to be seated first. The youth sat. Then, the adults moved, making it necessary for the young people to adjust their seating. They are not supposed to occupy the seats until the adults have been seated; often, there were just a few left for them. After church worship, they cannot exit until the adults have gone. The long queue of adults, talking and greeting, blocked their exit. Eventually, the young people had come to feel their unimportance and subsequently stopped attending worship. This undue handling has caused a total break of relationships between them and the leadership and their parents (Personal communication, Isaac Sarfoh, Personal communication, 2008).

Clapp and Cook (1981) mentions several forces in society that have a significant impact on the development of the youth. He mentions the increase of loneliness of many youth due to absence of parental care (pp. 1, 2). It would appear that the Scriptures encourage the church to correlate adults to be instructors, helpers, and mentors of youth as Paul did to Timothy (1 Tim 2:10). The church needs more time to develop relationship with the young people. Lawrence (2008) comments that the fast rate at which the youth are vanishing is alarming. He continued, "Relationships are keys to worthy youth ministry. The young people need adults who have gained wisdom through personal experience with God to relate to them (p. 26). The first task of adults and youth workers is to be with the youth just as Jesus was with the people (Lawrence, 2008, p. 180). As a 
sense of belonging grows, and as the youth build relationship with adults and other youth, they receive love and in turn love others (Lawrence, 2008, p. 139). This aspect of relationships is found in the creation of man, as Scottie, Posterski, Stonehouse and Cannell (2005) suggest that 'Then God said, Let us create humankind in our own image' (Gen 1:26). We discover that God is in us a relational being (p. 128).

Youth Ministry through the Gifts of the Holy Spirit

The call to be a disciple does not originate in fear and should provide a spirit of freedom (Gal 5:13). As sons and daughters of God, the Holy Spirit guarantees every single person a complete ministry. The promise of the Holy Spirit to the early church indicates a willingness to work with any person (Acts 1:8). Based on Ellen White's remarks, Jesus offered Himself as a sacrificial Victim and instructed His disciples of the "gift which He was to bestow upon His followers-the gift that will bring within their reach the boundless resource of His grace" (White, 1985, p. 47, 50). It is a universal promise, which is "for you and your children and for all who are far off-for all whom the Lord will call" (Acts 2:39). Paul describes the gifts "to prepare God's people for work of service, so that the body of Christ may be built" (Eph 4:12). Equipped and empowered by the Spirit, every Christian was given a ministry; none was exempt.

\section{Recommendations}

After carefully considering the activities involved in the incarnation of Christ as seen in John 13, Phil 2: 5-8; Isaiah 53:2-9, I am proposing an incarnational model of youth ministry for the Bantama SDA church. This model, when carefully examined and acted upon, may not necessarily solve the entirety of the problems overnight. However, 
there is the tendency that a sound and healthy relationship between the young people and their parents, as well as between church leaders and young people, will be established. The young people will freely relate to the church leaders and become excited as they are now involved in church leadership and worship. The Bantama Church will experience total coordination between the young people and the church leadership. This cooperation will also be manifested in the family as the relationships grow each day.

\section{Summary}

An incarnational model for youth ministry is offering a guide that is rooted in the life of Jesus. This is a model for the church today, and one which the Bantama Church is experiencing. The young people are working hand-in-hand with the adults without the fear of expressing their ideas. Every aspect of the incarnational model is teaching tremendous lessons to the Bantama Church today. Being commonly referred to as the future leaders of tomorrow, the incarnational model needs to become the supreme example. Every person in the church is highly recognized, and every department has a role for the young people to play. Now the young people have better relationships with their leaders, parents and other adults in the church. Their new ideas and energy are making every ministry come alive. Surprisingly, the young people, with support from their leaders, are planning retreats, youth camps seminars, outreach programs and other spiritual nurturing activities. Because of the empowerment, they feel ownership and are committed more to the point that church activities become a passion and priority. This model cannot fail, because it is a divine one. 


\section{CHAPTER 5}

\section{DEVELOPING CONTEMPORARY STRATEGIES FOR YOUTH MINISTRY FOR THE BANTAMA CHURCH}

\section{Introduction}

In the previous chapters, I described the theological foundation related to successful incarnational youth ministry. I also identified and described some young people in both the Old and New Testaments whom God used in different places for ministry. Although the church is positive in their relationship with young people there are some signs of existing cultural beliefs that do not allow youth to merge with adults. The understanding of this culture and the problems associated with it has made it impossible for the young people to express their ideas in church meetings.

To improve the relationships existing between young people and adults calls for a strategy to implement the incarnation model for the youth. This strategy reminds the entire church about the importance of youth. It, therefore, calls for the need to change the mindset of the adults by educating the church on God's position on relationship. The training is in three major areas: Training adults/church leaders in incarnational model ministry, training the young people in obedience, and developing parental relationship skills. The model is helpful only when the church acts upon it. 


\section{History of Bantama Seventh-day Adventist Church}

The church was established in 1972 by a group of laymen led by Pastor Matthew A. Bediako. Biblical teachings were mainly for the adults and the youth were left on their own. As a result, the spiritual foundation of the youth was not encouraged. Many of them took to their own ways and eventually came into conflict with church leaders and their parents at home. The following is a list of some of the concerns held by the youth:

1. They felt ignored in active participation of church activities.

2. They were denied participation in decision-making.

3. The adults did not attend their meetings and therefore, the youth had no guidance in their own programs.

4. They were labeled as "nkwadaa," which literally means "slave always," "serving always," "frequent servers" (McCaskie, 1996).

5. They were only recognized for physical work, and not at all for church administration.

6. At their youth meetings, they engaged in watching circular movies and other fanfare programs that are harmful to their lives.

In this chapter, I am proposing a training strategy that will address the issues confronting the Bantama Church. I am hopeful that this strategy will gradually bring the young people, leaders, and the adults together for effective ministry. As the Bantama Church understands and implements the model, where there has been violence, there will . be peace, and spirited passion will replace passion for the spirit. Where abuse of any kind had reigned, sobriety will rule. The cultural atmosphere of the Bantama Church can and will change, and peace will be enjoyed. 


\section{The Asante Cultural Mindset}

The Asante kingdom was the largest and most prestigious of the chiefdoms of Ghana. It emerged under the Asantehene (chief) Osei Tutu in the 1670 s as a powerful kingdom. The Asantes believed that young people were to be carriers of the Asantehenes (chiefs) to secure their matrilineal system of inheritance.

The Meaning of Nkwadaa in the Asante Culture

Nkwadaa, (plural noun) is a term for young people in the Asante-Twi language. It literally means "one always sent" or people bound to do menial work only" (Adu Boahen, 2003). As nkwadaa, young people, they are mostly found to be carriers for Asante chiefs. Because of their status as Nkwadaa, they are denied being present at gatherings that involve adults.

\section{Broken Relationships between Adults and Youth}

The rapid decline of youth activities is in part attributed to broken relationships between leaders/parents and young people. There is no one to encourage, inspire, and lead them. Because of unforeseen pressures, their interests in relationships and involvement are quickly diminishing. These are not familiar to the parents, and therefore, parents "sense gradual loss of influence and control they have for the adolescents" (Atkinson, 1997). Broken relationships with their parents have resulted in deviant behaviors (Csikszentmilhalyi and Larson, 1986, p. 156).

To repair the broken relationships between the youth and their parents as well as the church leadership, Donald Poterski has suggested the following three possibilities:

1. Leaders/parents must work together to build relationships, and consider 
nurturing relationships with youth as an effective tool.

2. Leaders/parents must place high priorities on youth activities and their meetings.

3. Relationally, church leaders and parents must be warm with the youth, seek their welfare, and understand the culture of their world today.

Tony Hershey (1994) believes that "the effectiveness of our ministry is tied to clear understanding of the needs of the youth whom we are called to serve" (p. 169). The only solution is the possibility of a renewed heart and mind when leaders and parents yield to the conviction of the Holy Spirit (Ezek 36:26).

\section{Changing the Cultural Mindset of Adults}

The Incarnational model for youth ministry will be ineffective, its implications will not be meaningful, if Christian cultural values and beliefs are not biblical. Although young people are growing, their growth does not correspond to their spirituality. The leadership training approach is put in place to facilitate the understanding of change of the cultural mindset of the entire church. The outcome may not be instant, except with continuous emphasis on the training. The admonition of Paul that we should not conform to the pattern of this world, but to be transformed by the renewing of our minds" is a worthy element of change (Rom 12:3). McKenzie (June, 2000) says, "Change does not happen anywhere simply because you upgrade equipment, grab onto best technology, do research projects, or just think about making change. Change happens when the mind and heart yield to the dictates of the Holy Spirit must start from the mind and heart" (p. 43, 44).

As a training strategy, Jesus initiated lessons by raising the disciples' curiosity 
through questions. He then expounded the Scriptures "and opened their understanding, that they might comprehend the Scriptures" (Luke 24: 45). We do not need to quarrel in order to get their attention for change. Rather, concentrate on the training aspect for the leaders of the church. Below is an example of lessons for the training.

\section{TABLE 1}

Lessons for Leadership Training

Lesson Topics and Scriptural

Study of Scriptures

Value of Wisdom

Knowledge of God

Christ's Glory

Doers of the Word

Thorough Search for Salvation

Purpóse of God's Word

Application of God's Word
Texts

Ps 119:105

Pro 2:1-6

John 5:39

Luke $24: 24,27$

Luke 8:21

Acts 17:11

Rom 15:4

Jas 2:10-12

Jesus' Model of Leadership through Incarnational Ministry

In previous chapters, I showed the importance of the themes in Jesus' life which often focused on his incarnation. Although he was in the very nature of God he did not consider it equally with God, but made himself nothing, taking on the nature of a servant (Phil 2:6). Though Jesus was God, but became fully man in order to reach humanity. The leaders are responding to the leadership training and are enjoying every bit of it. 
Interestingly, the incarnational model is influencing them as they share leadership experiences in four ways:

1. Submission characterized in Jesus' incarnational model of ministry (Christ's nature). The leaders do it for the youth to see (Isaiah 53).

2. Servant leadership. The leaders do it with the youth (involvement) (John 6:1$15)$.

3. Non-coercive power. (incarnational model). The youth do it with the leaders (participative) (Matt 28:20).

4. Participative. Leaders involve, train and empower the young people (sharing). Finally, the youth do it without the leader (Luke 9:1-6).

\section{Characteristics of Unhealthy Leadership}

Leadership becomes unhealthy if the main expectation is only to lead and make key decisions. El-Meligi (2005) states that the controversy that rages around leadership can never be settled unless we share the definition of words we use (p. 11). In a preparation for an annual camp meeting I took it upon myself to do the planning, and worked alone to get everything set for the occasion. In the evaluation, I scored negative marks because all the churches were displeased with my efforts. They needed to share responsibilities equally but were denied doing so. Pearce and Conger (2003) maintain that "leadership is unhealthy when there is no composed team spirit approach" (p. 105). A common adage says, "If a man does not keep pace with his companions, it is because he hears a different drummer. He does not trust that drummer except if it were his." A group functions more effectively when all its members accept responsibility for the work and life of the group. In this setting, leadership, of course, becomes healthy. 


\section{Developing Parents' Relationship Skills with Youth}

The youth need their familiès as they develop in the transition from youth to adulthood. Maxwell (1993) identifies the home as a place where the youth have their primary influence (p. 19). When "parents are exemplars of personal faith, our lives become the product of all of our witnessing to His majesty and power. Now, we haven't had anything to do with the gift, but we have everything to do with its discovery" (Maxwell, 1993, p. 41). Strommen (1997), religious educator and researcher, shares how change can happen in six steps:

F - Free people to participate. Help them to make a decision.

U - Unite around needs. Try to hide nothing from them and provide basic needs.

$\mathrm{T}$ - Tie to mission and values. Let them know reasons for what needs to be done.

U - Use input of legitimizer. Provide rightful assistance.

R - Rally broad ownership. Let them know they are partners in progress.

E - Engage in action. Assure them of improvement (pp. 60-148). God requires a lot from parents. Based on my experience as a district pastor of the Bantama district in which the Bantama Church is located, I am suggesting that the following steps will help parents improve their relational skills with the youth:

1. Adapt Biblical approaches employed in ancient times, like family devotions.

2. Take time to reason with the youth and consider that they have good things to suggest.

3. Treat the youth with respect and honor, knowing they are also God's legacy.

4. Direct the activities of the youth, but allow them to have decision-making power, because they are quick thinkers. 
5. Be proud of any youth in your home.

Elsie, my daughter, once remarked at our home devotion that parents should provide a role model that is likely to be emulated by the youth.

\section{Improving Young People and their Parents' Relationship}

Young people are the assets of the parents and the future leaders of the church. They need to understand the relationship that should exist between them and their parents. The Bible teaches about some young people who demonstrated obedience to their parents, which must be a guide to the youth of today.

\section{Obedient to Parents}

According to Kessler (2004), Isaac was an obedient young person who matched the faithfulness of his father. He listened to Abraham's word with noble spirit and joy (p. 120). Kessler (2004) further notes that Isaac's voluntary acceptance of the proposed sacrifice in his youthful age was the fact that he was obedient to his father (p. 120). Ellen White (1898) indicates that the life of Jesus was a life in harmony with God. Jesus did not ignore his relation to his earthly parents. He acknowledged the tie that bound him to the home at Nazareth, where he performed the duties of a son, brother, friend, and a citizen (1898, pp. 71, 82). During these years, families and the church must assume the heavy responsibility of nurturing the youth. Jesus grew up in such an environment. $\mathrm{He}$ emerged from his home obedient and respectful of his parents (White, 1942, p. 39). Root (2004) asserts that "it is not enough to walk with the youth in their darkened condition. We must also provide them light within this dark world and provide a path to Christ based on obedience" (p. 108). The church and youth leaders must teach the youth lessons 
about obedience (see Table 2). The youth need training in workshops, seminars, and youth camps to afford them enough knowledge and skills to relate well with their parents and Jesus (see Table 3).

Table 2

Lessons about Obedience for the Young people

Bible References $\quad$ Important Assumptions

Prov 17:6

Deut 10:12, Rev 14:7

Micah 6:8; Prov 22:6

Exod 20:12; Eph 6:1,2; Col 6:20

Gen 27:8

Prov 1:8

Col 3:20
Youth are the crown of old men.

Fear of God.

Obedience to parents.

Need to walk in the ways of the Lord.

Honor and obey parents.

Hear the instruction of parents.

Pleasing to God. 
Table 3

Timetable for Leadership Training .

\begin{tabular}{lll}
\hline First Quarter Items & Major Emphasis & Monthly Activity \\
\hline January & Culture & Bible Studies \\
February & Leadership \& Culture & Bible Studies \\
March & Unhealthy Leadership & Bible Studies
\end{tabular}

Second Quarter

April Parents and Youth Relationship Seminar

May Role of the Youth in the Home Symposium

June Principles of Obedience . Seminar

Third Quarter

\begin{tabular}{lll}
\hline July & Principles of Incarnational Ministry & Bible Studies \\
August & The Bible and Culture & Panel Discussion \\
September & Career Counseling & Retreat \\
\hline Fourth Quarter & Principles of Hermeneutics & Bible Studies \\
\hline October & Camp Meeting & Youth Participation \\
November & Youth Camp & Youth Participation \\
December & &
\end{tabular}

Results

As a result of incorporating the suggestions, the seed of unity was manifested in the family and the church. The' youth are enjoying a fuller relationship with their parents, 
church leaders, and the entire group of adults. They are now finding proper direction in their programs. Although there is a diversity of opinions due to different ethnic backgrounds, there is unity in the diversity. The strife for supremacy and the belittling of another is diminishing. To justify the efficiency of time, the table required some input, personnel, and equipment. In the following section, I will show their importance and where to find these items.

\section{Input Needed}

Budget

Bantama Church now has a place in their annual budget for youth activities. The youth have enough money for their activities. The youth council was empowered and they list and group events and activities according to areas within the youth ministry calendar. Table 4 is the outcome:

\section{TABLE 4}

Summary of Budget

\begin{tabular}{lr}
\hline Narrative & Funds $^{\star}$ \\
\hline Youth Leadership Training & $\$ 50$ \\
Youth Council meetings & $\$ 40$ \\
Youth Games & $\$ 20$ \\
Youth Camp and Retreat & $\$ 60$ \\
Equipment & $\$ 150$ \\
Total & $\$ 370$ \\
\hline
\end{tabular}

*These figures represent USD based on the Ghanaian cedi exchange rate. 


\section{Summary of Personnel}

Pastors. The pastors help incorporate youth ministry into the activities of the congregation. They encourage participation in worship and in all youth programs. The pastor's theological training is a rich source of knowledge for training youth to conduct Bible studies and introduce topics for discussion.

Teachers. The methods learned and practiced by teachers help them provide excellent techniques in working with the youth. Their participation will enhance the skills the youth need in their daily lives.

Parents. Parents and guardians have a particular interest in the spirituality of the youth. It is always better that the youth watch their parents using their area of expertise in their programming. It is recommended that there be a "parents' night" at least once a year.

Church elders. Elders are surrogate parents. Including rotating elders in the youth council and having them make suggestions in meetings is recommended. When they are involved in youth programs, it promotes maturity in the decision-making process.

Invited guests. The youth are inspired more when they listen to new speakers. They may reach out to include guests in their programs, but that should be approved by the youth council.

Equipment. Teaching materials are indispensable and may include, but are not limited to the following: books, magazines, articles, journals, photographs, and others.

Training venues. Select a location which will allow the youth to spread out for small group discussion and prayers. The venue, besides church premises, should have 
most of the equipment available for the program.

Transportation. If the church does not have an official vehicle, this becomes another vital item to consider.

\section{Bantama Church}

The Bantama Church is the nucleus of CGC of SDA churches in Kumasi, Ghana. The church has the highest number of youth in the conference. The youth form about one-third of the membership of Bantama. Since the establishment of the church, the youth are famous for performances during public festivities, especially for burial celebrations. Due to their spectacular performances, other conferences invite them, and that has been another means of raising funds for the church. However, the church leadership seems to have forgotten a role the youth can do. In spite of their growing number, there has not been a volunteer or a hired youth pastor. The youth are not participating in church activities and are, therefore, losing interest in Sabbath worships.

\section{Process of Organization}

To have any meaningful and successful ministry, it is important to put in place a process of organization. It enhances a clear purpose of direction to achieve a goal by setting proper priorities. In order to achieve any meaningful goal, the needs of youth need to be identified.

\section{Identification Needs}

Bantama Church does not have a youth pastor and does not involve volunteers in the youth program. As a district pastor, Bantama Church is my local church. I usually consider the need to improve the youth ministry. The young people are labeled as 
nkwadaa, literally meaning "always slaves" or kids in the church. They cannot fit in any leadership role. However, they are starving for the righteousness of God which a parent describes as "need of spiritual support" (interaction with a parent).

It is necessary to create a ministry to meet the needs of the youth so that they can share experiences in a safe place and help one another. To achieve this mission, an incarnational model that needs full youth participation is on-going. This model is providing a solution to the question of the young people's participation, and promoting better interpersonal relationships among the church. Every church member is part of the solution, because "everyone experiences leadership" (Blackaby \& Blackaby, 2001, p. 3). Therefore, every church member is enjoying leadership within his or her environment.

\section{Youth Council}

The basic needs are identified and the desire to strengthen the youth ministry is clear. The next step is to create a youth council that suggests a means of achieving the identified needs. Membership includes the district pastor, youth leader, assistant youth leader, youth sponsor, two church elders, a representative from women's ministry, and interest coordinator. In February 2002, the Bantama Church Board convenes an official board meeting and invites all the Youth Council members to attend and introduce themselves. The church at business recognizes the council and accepts them.

The first youth council meeting was held a few days after the church's decision, and the needs of the youth were made clear. Many programs were outlined that helped resolve the needs of the youth. The programs are in three main categories: (a) spiritual, (b) social, and (c) educational programs. The purpose is to improve the relationship of the youth with God, parents, and church leadership. It specifically encourages youth 
participation in church programs. Some specific programs included encouraging home devotions, worship, retreats, evangelism, youth camps, community services, and youth games. The first program is to begin home devotions. The church secretary promotes the importance of the program to the entire church. I educate the church on the need of home devotions and explain the relevance of total participation of all family members. The council also seeks means to look for either an adult volunteer or a part time youth worker to help the district pastor. Two Bantama Church elders volunteer. Before the work of the youth council progresses, they come up with a mission statement as a guide. It reads: "Encourage the youth's commitment to a personal and everlasting relationship with Jesus Christ and man. Seek involvement, mentor them towards wholeness within a supportive church community and empower them to bring healing and hope to the world."

Home devotion in the homes of various members is gaining momentum. Both parents and the young people are testifying of God's tremendous blessings over the families. The council becomes the backbone of the new approach to structure youth ministries in the Bantama Church. Many suggestions come from parents, church leaders, and the youth asking for some other inspiring programs. The youth council evaluates the program with the intention of fixing the weaknesses, upgrading the strengths, and considering more appropriate programs in the future for the Bantama youth ministry.

The Bantama Church board congratulates the youth for the convincing reports from their parents. In the second quarter of 2002 , the council found a need for more programs which require a sub-council. This council is comprised of four members: one youth, one elder of the church, a youth worker, and the district pastor. They were to supervise the activities of the youth, interact with the parents and church leadership, and 
then submit reports to the youth council monthly. They were also to share their experiences and plans for the council. The youth council held monthly meetings where the sub-council submitted their reports and subsequent plans. All participants take notes in the meetings based on asking questions, giving answers, and making suggestions. The youth secretary takes notes for the end-of-year youth meeting.

The youth council not only concentrates on balanced youth programs, but also perceives the level of youth involvement in the programs. It is the involvement of the youth and adults of the church that brings about the success of the program. As mentioned above, the programs are tested and can be applied in the Bantama Church situation. I am examining them under the following categories: spiritual, social, and educational.

\section{Spiritual Activity}

Alone with God-Home Devotion

Research shows that the youth relationship of faith in daily life has changed the lives of many young people. In all the largest Christian bodies in Ghana, fewer church families are producing the kind of youth whose hearts are committed to the mission of Jesus Christ (Fynn, October 2005). According to Barna (1993), this is because the tradition of passing on faith in the homes is disappearing for many Christians.

This section deals with a model of strong life-shaping family devotions. The purpose is to build and maintain two key relationships--a strong family relationship and a relationship with God. This model was once tested in my ministry with huge success. The youth can work together with the adults and explore their religious commitment to God. 


\section{Sabbath Morning Worship-in-Prayer}

In order to pass on the faith from one generation to other generation, a new paradigm of ministry is needed - one that is holistic and connects the youth with their parents and other adults. This program is still producing tremendous results at Sefwi Bekwai where I served before coming to the Bantama church. It is a twenty-minute prayer-worship every Sabbath morning. The lives of the youth were filled with distractions and non-useful activities, leaving little time for quiet reflection. Therefore, a prime role of worship can help them become focused and connected with God's presence. It is only as they are involved in worship that they can realize the importance of God in their lives.

\section{Program Description}

The young people conduct the Sabbath morning worship-in-prayer with the adults every Sabbath. To do this, there is a seminar for the entire church. The purpose is to create an environment of worship participation for the young people and strengthen their spirituality. It starts immediately after the Sabbath school lesson. There is variety in its format: prayer, praise singing, short symposium, interview, or testimony

The young people often conduct the programs but sometimes do so with the adults in the church. Since there are different programs every Sabbath, different people lead out. It is always interesting to see the young people performing together with their parents, church leaders, and other non-churched peers. They go to the pulpit to sing and take part in the programs for twenty minutes. The role of the adults in the Sabbath morning prayer-in-worship is to encourage unity. It also informs the entire church about preparing the young people for the future church. The adults demonstrate their 
experiences for the young people to watch. They then perform with young people, after which the young people perform on their own.

\section{Results}

The youth council and all of its sub-committees prepare the programs. The parttime youth workers, parents, and adults share their vision. They are excited about the results they are observing. They are not just helping the youth as a favor, but rather are sure that God is commissioning them and that the youth are their team members and colleagues. There is a sharing of leadership and the young people are playing their part in their homes and in the church. The strategy which is demonstrated in the incarnational model is actively involving the entire church into ministry.

\section{Evaluation}

The young people have found their way into the church program and are passionate about their participation. We are drawing attention with the time factor and trying to desist from the common saying of "African time." The youth must perform within time accorded them to enable other programs to end on time (1Cor 14:48). A full time youth pastor would be commendable for the Conference to hire.

\section{Youth Meetings}

The information contained in this section is gathered from a personal interview with the Bantama district pastor and some of the church elders. In October 2006, the church's record indicated that there were about 1200 members, with about 105 of them being youth; however, there were no formal programs or youth meetings. The youth were not studying the Scriptures and therefore, were unfamiliar with the doctrines of the 
church. This is a great responsibility as there is no full-time paid youth pastor to guide them and take responsibility for their activities. The district pastor's need to cover twenty churches in the district made it impossible to be efficient with the youth. The Bantama Church Board recognized the need and gave Monday and Friday nights throughout the year for youth activities. They consulted with the Conference leaders and asked for a fulltime youth pastor. In the absence of an approved budget, they decided to hire one on their own. The council met with the district pastor and started a program on "How to study the Bible." The program was to motivate the interest of the youth towards the study of the Scriptures. It was also to help them understand the doctrines of the church. As a result, their spirituality developed and they shared their personal experiences with Christ with others.

\section{Program Description}

On Monday nights, the program lasts one and a half hour at the church house. It starts at 7:00 p.m. and lasts until 8:30 p.m. The youth council sends the item on the program to either a local or invited speaker. The attendance record is very impressive and is comprised of the youth and many of their non-Adventist friends, parents, adults, and church leaders. The program begins with fifteen minutes of songs of praise. All the instruments are intended to create a spiritual background through the rhythm of the songs. Each presentation lasts for twenty minutes on a slide projector. Ten minutes are given for questions everyone can answer. The youth, adults, and church members present their views towards any question, making the program unique. Finally, the presenter summarizes the lessons. The youth secretary also presents the announcements and reminds participants of the plans for the following week. One member of the youth group 
comes forward to offer the benediction and asks all the participants to greet one another at the end the program.

Activities for Friday nights include (a) "Heart to Heart" where a few people describe Bible characters and show how they impact them. (b) Sometimes a person from each family is selected to form a panel. They answer questions from the floor on a particular subject. After that, the panel selects hymns as the entire church sing to close the program. (c) Pick and Act: Different questions are written on papers and are neatly folded. The questions are spread on table, where a representative from each group picks one and reacts. (c) Seminar, retreat, symposiums, youth fellowship days are held at different times of the year. Guest speakers include some young people of the church, church pastor, or any church leader. The youth council in collaboration with the Church Board comes up with topics for presentation. Small groups are put in place for discussion and a group leader submits a summary of their discussion to the church.

The church sings of song praise to end the program. The beauty of the program connects one to another with greetings.

\section{Results}

The Bantama Church is now observing organized groups of young people who are inspired to contribute their quota to the development of God's cause. The implementation of various programs on Friday and Monday nights reflects a continuous increase in attendance. There is a tremendous increase of youth membership in the church. There is good connection for making their voices heard. Besides the growth, the young people are finding themselves where they were not allowed before. Turnout in Sabbath vespers is changing dramatically because every one wants to be seen. 


\section{Evaluation}

Time consciousness is an area that needs to be improved upon. Those who lead out in various programs are not mindful about when they should end, especially when programs become interesting. It affects punctuality on Sabbath which is not part of the goal for youth ministry. Extra caution should be taken of the integration of the youth, because people around Bantama Church are suspicious of the inappropriate behavior of the youth. However, the district pastor and the part-time youth workers are equipping the youth for successful ministry. Many parents and Bantama Church leaders are satisfied with the role of their children and the cordiality that is transpiring in them. A full time youth pastor for a growing youth group to organize and supervise youth activities is an embedded challenge. All the programs do not emerge just to fill a slot or meet a requirement, but rather to involve and train the youth to meet a specific need. These programs have been the basic step to develop healthy interpersonal relationships and growth in the Bantama Church.

\section{Social Program}

Retreat

The Bantama Church is experiencing a profound transformation in the lives of the youth and adults. The church leaders, parents and all other adults understand the principles of incarnation, and are applying them in the homes and in the church. The church leadership is incorporating the youth into discipleship. The youth are calling for some more social programs because it is an easy means to reach their peers outside the church. The youth council proceeds to propose retreat programs, which come once per quarter. It was nicknamed "Getting-to-Know-You." The retreat has two-fold purposes: 
(a) it provides increased knowledge and application of the Bible to life, (b) it fosters better interpersonal relationships in the campers' lives. The first assumption the youth council makes targets youth and adults.

\section{Program Description}

The youth council proposes a retreat program that takes place once a year. It is scheduled normally between July and August. At this time many of youth who go to school in different places are back home for holidays. The entire youth group leaves home for three days, beginning on Friday and ending on Sunday. The retreat usually goes to any location that has the facilities needed to service the group: recreation, lodging, kitchen, and meeting place. A lot of attention is not focused on the beauty of the place when looking for a site, but whether the use of the particular site will facilitate achieving the desirable outcomes.

The youth council meets to appoint the following committees and their responsibilities:

1. Program committee: For the supervision and management of total resources

2. Personnel publicity
Activity
Brochures
Program sheets
Topics to be treated

3. Accommodation committee

Accommodation

Retreat site 
4. Finance committee:

\section{Funds}

5. Transportation committee:

\section{Transport services}

6. Security:

Keeping campers safe

7. Equipment and public address system committee:

Necessary equipment is secured:

Projector

Computer, $\mathrm{CD}$-rom.

The youth council limits all the committees to a time frame to submit their reports for approval. Various committees submit their reports to the youth council to be implemented. The date for the retreat and everything else is set. Brochures are posted all over Bantama Church and its environs. The church board gives the retreat outstanding publicity at its meetings and members respond to registration.

The program components for the retreat are as follows:

1. Bible study and instruction

2. Worship, witnessing, and music nights 
Table 5

Summary of Retreat Timetable

\section{FRIDAY EVENING}

3:30 p.m. Register at the church; final payment of retreat fees, and accommodation

4: 30 p. m. Departure for the retreat

6:00 p.m. Dinner (optional)

8:00 p. m. Arrival at retreat center

9:00 p. m. Opening session

10:30 p: m. Bed time: Lights out

\section{SATURDAY}

4:30 a. m. Rising up and preparation

5:30 a. m. Devotion

8:00 a.m. Breakfast

10:00 a.m. Sabbath school lesson study

12:00 a.m. Divine Service

2:00 p. m. Lunch and break

3:00 p. m. Afternoon sessions

4:00 p. m. Dinner

7:00 p.m. Fellowship

9:00 p. m. Bed time: Lights out

\section{SUNDAY}

9:30 a. m. Morning sessions

12: 30 p.m. $\quad$ End of retreat 
Results

Interestingly, campers are enjoying all the items that are taking place. For some, this is their first experience. The youth have the opportunity to share their joys wit their parents and neighbors. They are exploring new things as they go hiking. Different activities at the retreat are enriching their spirituality. Parents are excited to see better relationships going on in their homes. They now believe that since young people spend much of their time in the home, the parents pledge to continue building this spirituality in their own personal devotions. Sabbath school, Personal Ministry and other departments are full of participation by young people. Young people are organized and thus, are working with the adults in their own church setting.

The retreat has been a powerful instrument for the youth and the adults because all participants have realized a deep commitment to Jesus. The adults attend which had previously not happened. They share their experiences with the youth by interacting with them. The retreat has also been beneficial to the youth because it is blending that which was once split. The recognition of the unity among the youth and the adults is due to a lot of prayers and sharing. The Bantama Church is benefiting from the program, not because of meeting the youth's need alone, but also because of their willingness to serve God and be loyal to the adults. The retreat meets the social needs of the youth, especially because they make new friends.

\section{Evaluation}

Though the program is vibrant and ideal, there was the need to commend the high attendance of the youth and adults of the Bantama Church. There is no known record of a retreat program held for Bantama youth ministry. The youth and adults could at least 
work together without having problem with cultural differences. The spirit of interconnectedness is being rekindled in each group. This is inspiring the youth to participate in church activities at any level required of them. Other adults who visit on Sabbath testify of the unity and the role of the youth in Sabbath worship. The Bantama Church is benefiting because of the unity between the youth and adults where there was none at one time. Other than this, there are a few indications of lapses in the work of the various committees. This shows improper planning because there are enough links between the youth council and the committees. Leadership must be shared in order to raise the spirit of teamwork. These failures are characterized in constant power outrages, insufficient rooms for campers and continuous complaints of insufficient food. Practical lessons are taught which can easily be applied. Based on the performance of individuals at the retreat, the district pastor sees it fitting to give a B grade.

\section{Friendship Evangelism}

The youth council and the administrative team put in place all that is required for friendship evangelism to take place. The youth go through a series of training and want to reestablish relationship with their peers who join them in soccer. This is an opportunity for reconciliation. As the adults mingle with the young people in soccer, the young people become excited. This becomes an opportunity to build a viable relationship between the adults and the young people. Attendance of both adults and young people at youth meetings surprisingly increases. The Bantama Church is carrying out teamwork in evangelism and both parties are participating fully. The adults have the chance to share their spiritual experiences with the young people, narrowing the cultural gap and making their relationship a key substance. 
The Bantama Church Board agrees to a-two-week evangelism series led by a young person. For the sake of home visitation, the entire church is divided into groups of six. It involves three adults and three young people. They go out to distribute books, pamphlets, and magazines. Most of their friends are excited about the relationship with the adults. They join their friends in their meetings to hear the Word of God.

\section{Program Description}

Friendship evangelism takes a different form. The church pastor leads out training the church on "How to give Bible studies for one week." The training equips both the young people and the adults. The Youth Council consults with the Church Board and arranges a soccer tournament for the young people. This is a means to reach non-church youth. The Church Board provides money for food for the entire player and the fans. The match is played on Sunday where many people come to watch.

Before the game begins, one elder calls all participants to the center of the pitch and speaks to them on the purpose of the game. Prayer is said and the game begins. After the game, both sides are entertained with food, despite who won or lost, and all the players and spectators are invited to youth programs. The youth and adults give a short review of the game. The youth leaders take the opportunity to explain the forth-coming friendship evangelism to the young people. They invite everyone and ask them to extend invitations to their friends.

\section{Results}

Attendance of youth meetings attendance increases from time to time. Nonchurched youth are motivated to join their peers for Bible studies. The lives of the young 
people are changing; they love God more than ever and are curious to introduce their new found faith to their friends. Although they do not have any formal training, social activities are becoming an avenue for training them to win souls for Christ.

\section{Evaluation}

It is always best not to force tough theological insights on young people. When they are not up to that level it is difficult for them make sense of it. We start with what they know, what they are used to, but which is not contrary to God's expectation. The basic reason for the game must not be just to play. The underlying factor is a means to reach the youth. They attend meetings on time and spend the entire period listening and contributing.

\section{Week of Spiritual Emphasis}

A two-week workshop is planned to prepare the young people's commitment to God. The life of Christ is reproduced in us by the power of the Holy Spirit. As an inner work of God, "it is achieved by human effort by divine enabling" (Gal 5:22).Based on what the cross stands for, the young people want to be connected.

\section{Program Description}

Copies of AY Week of Prayer materials and some outlined programs are designed and made available to the audience. Various societies in the church are to be in their different uniforms, for example ushers, deacons, women's ministry, dorcas and welfare, and the youth. Prior to the commencement of the program, different activities take place. Singing groups are featured each night after which a short drama, health or family life presentation takes place. The speaker presents the message for forty-five minutes. It is 
followed by another song: All announcements related to the theme are made, followed by the benediction. The presentations are given by various speakers. It is intended to involve the youth and adults in assessing, evaluating, and working through detailed evidence for a particular viewpoint. The church is divided into small groups of not more than ten members. The grouping is comprised of youth and adults.

\section{Results}

The social atmosphere between the youth and the adults has been encouraging because both are able to come together in sharing with others. About fifteen of their peers have worshipped with them and have accepted Jesus as their Savior. New youth converts are surprised because their friends are participating in roles that are forbidden in their homes. Young people are not necessarily thrilled to attend a traditional Sabbath school when it is all about laws and regulations. Good interpersonal relationships, care for the young people and being like them is making difference in their lives. The level of commitment and unity being experienced among the youth and adults is a means of transforming the church into soul winning.

\section{Evaluation}

Although the Bantama Church is seeing the need to finance these programs, there is delay. Adults can help by executing socials and outings for the youth and by guiding the programs. When they are left on their own for the whole time, it is difficult for them to see their mistakes. While working with them, there could be areas in the program where the youth need practical coaching. It is important that activities be planned by the adolescents. However, since they do not always have all the expertise on all the youth 
ministry philosophy and purposes, they need to allow the youth to share ideas. The church is made with people and for people. It is the basic need for relationships. The need to be connected with one another is realized. There is team work in the church board, youth council and its subsidiaries. When the youth use their energy to complete ministry projects and goals alone, they buy what Troy Murphy (1977) describes as "the old plan of individualism" (p. 24).

\section{Youth Camp}

The Bantama Church is observing a great deal of growth in their youth characterized by their participation in church activities. The youth are continually growing and developing. The lives of the young people are making a marked impact in the Bantama community. The youth can develop best in the company of experienced understanding people, who know God and value them.

They are looking for an opportunity to move from repetitive schedules and uninterested activities to where they can meet God. Youth camps would be another opportunity for them to experience a lasting commitment and relationship with God.

\section{Program Description}

The church board empowers the Youth Council to organize youth camps for Bantama young people. The purpose is to bring all the young people to one place to learn, live, and work together and help them to relate both to peers and adults. Creative flyers, retreat brochures and handouts are sent out to attract people. The Bantama church secretary makes constant announcements to remind them to plan ahead.

The youth camp takes place in the third week of December each year. It is at this 
time that most of the students and adults are home for the Christmas and New Year holidays. The youth council forms all youth camp committees and all sub-committees. They assist in coordinating all matters with the board relating to the youth camp. They set the following committees which are approved by the council:

1. Steering Committees: They oversee the general program and all sub-committees so as to ensure that they are all on schedule regarding their responsibilities in terms of reference.

2. Program and Platform Committee: Responsible for the supervision and management of the daily program. The responsibilities include the following:

a. The organization and direction of every program.

b. Selection and arrangement of platform personnel to participate in each program.

c. Platform fixtures, including the platform pulpit, desk, and chairs for the platform and for the campers.

3. Equipment and Public Address System Committee: They are responsible for supervising and insuring that all the necessary pieces of equipment needed for the program are secured, and are not only in place, but are also functional throughout the duration of the program. The equipment includes the following:

a. The public address system and large screen

b. The electrical equipment.

c. The technical equipment, for example, projector computer, CD-Rom.

4. Visitation Committee: They are responsible for organizing campers for friendship evangelism. Their responsibilities included

a. The selection of visitation teams and assignment of territory for visitation. 
b. Regular and systematic evaluation of the visitation program.

c. Insuring that all visitors are duly recorded and visited.

d. Implementing the prayer plan for names appearing on records.

5. Decoration Committee: They are responsible for enhancing the beauty of the meeting place so as to insure the greatest appeal to the eye and senses. Their responsibilities included the following:

a. Securing and arrangement of attractive plants and flowers throughout the meeting place.

b. Securing better decorating materials for the platform.

c. Preparation of and hanging drapes when necessary.

d. Hanging of camp banner.

6. Advertising Committee and Promotion Committee: They responsible for insuring the most positive and widest publicity of the camp. They are also to supervise the printing/preparation and distribution of the following:

a. Personal invitations.

b. Handbills, posters, and banners

c. Radio, television, and newspaper ads.

d. Any other communication strategy that promotes and guarantees a large attendance.

7. Ushering and Greeting Committee: They are responsible for all the duties relating to welcoming and seating all guests. These includes

a. To stand out as genuine frontline representatives of the noble ideas of the program through their attire, deportment, friendliness, warmth and readiness to assist all 
visitors in any possible way. Duties include the following:

i. Warmly welcoming and seating every attendant.

ii. Providing assistance to campers where necessary.

iii. Collecting daily' offering

8. Music Committee: They are responsible for supervision and management of all the music for the camp. Responsible for supervision and arrangement of the total music for the program. It includes

a. Appointment of song leaders and organist for daily programs.

b. General supervision of the choirs (adult and youth) and other musical groups.

9. Budget Committee: They are responsible for supervising all finances which include

a. Daily purchases

b. Income

c. Accountability of camp expenses

All committees were to do the following:

i. Meet regularly for general review of the work of all the committees.

ii. Liaison with all the committees' chairpersons and received up-to-date reports from them.

iii. Be assisted and advised where necessary.

iv. The youth council met with all the chairpersons of all the committees at the end of every day's program (Boakye-Dankwa, 2000).

Adequate information was given to the church for the release of their children for the activity. Continuous notification about time, fees, and youths, and adults' plans to attend 
was given. In order for all the committees to have adequate preparation, the planning started at the beginning of year. In calculating per person costs, the following were considered:

1. Renting the facility

2. Food

3. Transportation

4. The speaker

5. Staff

6. Promotional brochures

7. Scholarship for the under-privileged to be sponsored

To meet some of these costs, the church board organized fund raising on two

Sabbaths. Some people donated money, cars, or food. Deadline for registration was the second week of September. The final reports of all committees came in and were critically approved. The budget committee submits the budget as follows:

Table 6

Budget Committee Proposed Budget

\begin{tabular}{lcc}
\hline Income & Projected & Actual \\
\hline Youth fees & $\$ 20$ & $\$ 15$ \\
Budget from Church & $\$ 50$ & $\$ 45$ \\
Fund raising & $\$ 55$ & $\$ 47$ \\
Parental support & $\$ 35$ & $\$ 32$ \\
Equipment, fuel and transportation & $\$ 40$ & $\$ 30$ \\
Total & $\$ 200$ & $\$ 169$ \\
\hline
\end{tabular}


This is a Ghanaian cedi equivalent in US dollar.

All of October was dedicated to leadership training. Much emphasis was placed on leaders for specialized activities and for the leadership team who would train in discipling. In order not to be disappointed with the equipment for the camp, the committee provided a list of camp equipment to the youth council to be checked. To ensure availability of these items, checking was done twice. The first check was done a week before and then, on the day the youth camp started. All committees were optimistic that everything was set for the program to begin. Accommodation, food, equipment and everything else was set and ready. All materials had already been checked to make sure that they were relevant to campers. The camp officers, including the district pastor and the volunteer youth workers, were the first to be at the camp ground. The final check was for the availability and completeness of all items. Campers were paired in each room with their programs in their hands. Every camper also received a badge and a meal ticket bearing his or her name for easy identification. Ten to fifteen youth and one adult were grouped together for all activities until the end of the camp. These small groups met, if required, after each presentation and prayer. On the first Sunday, all campers participated by going from the camp site to a natural bush setting. This is designed to get people away from their usual support systems to learn more about themselves, their own potential, human relationships and spirituality. The groups of youth and adults spent about six hours surveying the forest and demarcating it for hiking. Early in the morning, there were devotions. Immediately after that, the hiking rules were made clear. Groups were formed and the hiking began. Group leaders led out with campers singing, drumming and dancing as they went along and explored the beauty. They followed signs that directed 
them through the thick forest. All the groups returned by 4 p.m., got ready for dinner, and each group presented its report through their secretary at the evening meeting. Presents were given to the best group for identifying all hidden signs.

The camp taught a lot about the toils and sufferings of our pioneers and inspired the youth to a finished work.

Five youth were selected daily to assist kitchen staff in food preparation. In order that the kitchen staff might not miss any presentation, a big television screen was placed in the kitchen to transmit all programs. Campers were supposed to be in their rooms at 11 p.m. each night. Camp security went round to check that every camper was safely in his room. It was anticipated that all campers would be in their rooms, except for emergencies or those campers who had received special permission. Breaking camp rules was referred to a committee set up by the council for investigation. The recommendations were sent to the youth council who studied them for appropriate action. Punishments varied according to the offence. Some were sent to the kitchen to work for the rest of day; others worked on the ground for a couple of hours. Campers were sent back to their destinations when the offence was beyond the control of the youth council. Such offenders were referred to the church board for counseling. See Table 5: Timetable for Daily Schedule.

\section{Results}

This was a great time of reunion. The youth camp is an environment where they met their friends. They share their experiences and prayed. The youth connected well with their parents, peers and church leaders. Parents and church leaders had the opportunity to dialogue with the youth and get to know and understand them better. A 
notable result of the youth camp was that it created a profound experience in the sense of bonding the youth and adults together.

\section{Evaluation}

The young people loved the youth camp. The church leaders need to search for other means to get many parents to the youth camp. Those who cannot be resident campers can choose a convenient time to visit while camping is in progress. The district pastor's frequent unavailability is deeply felt. The Bantama Church wants to hire a youth pastor if the conference is not ready to do so. Care should be taken over the excessive behavior of youth when they emerge with the adults. The objective of the youth camp must be guarded in order not to replace it with only a fun fair. It should be a time to train and equip parents and other mentors to implement the biblical model of discipleship in the campers. Information from various committees should always get to the youth council. This will allow them to liaison with the church so as to pass information on to the entire church.

\section{Youth Investiture Service}

The Investiture service is the meeting at which the candidates are awarded their insignia after they have passed the tests and done the work that entitles them to become members of a Youth Ministry class. Perhaps nothing in connection with Youth class work affords a greater opportunity to magnify what is being done in the eyes of the members of the church than the Investiture service. Therefore, as a most important service, it is conducted in the most dignified manner. It is done in a way that stirs the heart of the young people for a desire to do more in the future. It is the powerful basis for the 
encouragement and salvation of our boys and girls. It also provides an environment for fellowship, inspiration, and training for service (Garcia-Marenko (ed.), 2000).

The purpose of the Investiture service is to graduate successful candidates who have received continuous education through training, and inspiration for the work of God. They come back to share their experiences with others through training and fellowship with Adventurers, Pathfinders, and Ambassadors.

\section{Program Description}

The youth leader presents the date, tentative program, and a venue for the Investiture service for approval. The church board orders Investiture materials needed for the occasion. Successful candidates go through the tests about one week before the Investiture service day. Candidates are selected and are ready.

Special guests from the government, Conference and the Asantehene are invited. Other non-Adventist churches and their leaders are also invited. The young people in their attire entertain the crowd with displays. It is followed by a short service. The representative for the government delivers his short keynote address. Then all the levels such as Pathfinders, Ambassadors, and senior Youth entertain the crowd with a short display. There is a parade that the local youth leader leads for the Conference Youth Director and some of the invited guests to inspect. The local youth leader presents the candidates to the Conference Youth Director, and then the Conference President offers the charge and presents the insignia. After that, he presents them with certificates. The Bantama Church elder offers a consecration prayer and there is a song to end the activity. 
Table 7

Investiture Service Program

Time Events

7:30 am Sing song

8:00 am Sabbath school action

9:00 am Short talk by Government representative

9: 20 am Music by youth and adult choirs

9: 35am Short talk by Asantehene (king)

9: 40 am Music by soloist

9:50 am . Youth recitals

10: 50 am Divine Service

11: 50 am Youth parade inspection Regional minister, military and police officers

12: $45 \mathrm{pm} \quad$ Local Youth Director leads Conference Youth Director, Military and Police officers for the Investiture

1: $30 \mathrm{pm} \quad$ Conference Youth President charges and presents insignia

2: $00 \mathrm{pm} \quad$ Consecration prayers and closing song

Youth entertains invited people with parade-optional to watch. 
The following are classes:

Primary Class

Busy Bee

Junior Class

Friend

Adventurers

Companion

Explorer

Senior Class

Guide

Master Guide

The Master Guides and the Guides take the responsibility of training the primary and the junior groups. They also help with the programs of all the young people.

\section{Results}

The Master Guides and Guides are sharing their experiences with the primary and junior levels at their meetings. This is inspiring all the levels of youth for better relationships. Every aspect of the Investiture service follows in order without complaint. Inspirations realized in the Investiture service also confirm the importance of the incarnational model. Each person is contributing in one way or another to building their faith. Parents, church leaders, and youth leaders of Bantama are experiencing harmony in their environment. The displays at the Investiture service alone have excited and attracted many unchurched youth to the church. 


\section{Evaluation}

Investiture is approved for the purpose of developing the character and giving young people the skills and knowledge of the Bible. The service motivates them to spiritual, physical, and moral standards in the Christian pursuit. If materials for the Investiture are ordered on time, it prevents a delay in the process. Many of the graduates are not satisfied in having their decoration. That alone can disappoint them, and may prevent them from being active. Daily class schedules must be supervised well in order to present more qualified candidates for the Investiture.

\section{Youth Games}

The church adopts other strategies for more lively opportunities to impact the lives of today's young people. It was a time of healing and renewal, a time when teenagers could share together, play together, and study God's Word together. It was a time when they could laugh together. Youth games were another means to increase their thirst for joy and companionship. These were indoor and outdoor games that attracted young people in the community. Indoor games involved Bible bowl, pick and act, mission impossible, Bible characters. Other outdoor games included soccer, ampe, tennis, and tug of war.

\section{Program Description}

Indoor Games:

Bible Bowl. This game normally took place in the church room and was mainly an exchange program. There was a negotiation with the nearest Adventist or nonAdventist church for a competition. A period of time was given to two or three different 
churches to study either about a prophet, priest or an event in the OT or NT. Each church presented the youth or adult to answer questions from the moderators. Marks were awarded to those who excel. Questions went from competitor to competitor until everyone was satisfied. Time was allotted to each competitor. Other youth and adults from the church and community applauded for their contestants, thus making the program lively. At the end of the game, the pastor gave a few remarks. He commended the participants, the contestants and the youth council. He also encouraged the youth to continue studying the Scriptures for a firm foundation. An elder and youth came in to present gifts to the contestants and to the churches. A parent was called to offer benediction.

Pick ' $n$ ' Act. In this indoor game, the youth were group in one side while the adults were on the other side. Many papers containing different acts were placed in a big basket for each group to pick one of the papers and acted accordingly. Failure to act exactly what was on the paper was a sign that home work was needed. This enabled individuals to pick and to act carefully.

Mission Impossible. This is an open game. An elder, parent or pastoral staff member was to leave the room briefly. The rest in the chapel decided on a specific object for the person outside to come in and identify. To identify the hidden object, the person asked questions about the pre-determined item. The congregation directed the person with "yes" or "no" answers. As he or she gradually came closer to identifying the object, the "yes" answers increased. It indicated that the contestant was close to winning. All the youth were happy as people struggled for answers.

Bible Characters. In this game, the youth were to pick their favorable Bible 
characters, like Moses, Daniel, John, or Paul. They were to study about them and present the most interesting features about them to the youth. Fifteen minutes were given for the presentation which was followed by questions: Many youth have been involved in studying about the work of Bible characters that have been their mentors.

Outdoor Games:

Soccer. About one-third of the youth converts have been generated from youth soccer. Ghana is a soccer country and the youth love it. The women's ministries participated fully in this program by cooking lunch and submitting snacks and bottles of water. They invited other churches and with strict regulations, played a ninety-minute game. At the end, they came together and ate while singing praises to the Lord. The youth leaders offered prayers and invited all the players to their youth meeting. At times transportation was provided for those living a distance away from the church.

Ampe. In this game, the ladies have the privilege to play with their mothers. It was always played when the moon was full. They made a big circle with one lady jumping into their opened hands. She was carefully thrown up in the air, and gently came down. They sang traditional songs by mentioning names of their future husbands. The mothers responded to the songs by agreeing to their proposals. It followed with Bible studies on choosing a life partner. Mothers attended to share their experiences with the young girls during the events.

Tennis. Either table or lawn tennis matches were played between the youth and parents. In this case there was a selected youth who act as umpire. The others watched the youth play against their parents.

Tug of War. This involved two groups pulling a rope until one side was 
victorious by pulling across an agreed-upon mark. There was a common mark upon which a group pulled across became the winner. This game may have mixed genders in each group, however, boys were delighted to compete with the girls as their parents and other friends watched and clapped for them.

\section{Results}

I call these times with the youth recreational periods. They express much joy in the various competitions outside the church environments: In these games, the focus is not on who wins, but rather is the means to enter the culture of the youth.

Many new friends are made and they often result in baptisms. Games become another effective tool of evangelism for the youth.

\section{Evaluation}

The church understands the role of games in the ministry of the youth, and then provides them with materials. They lack many of these materials and this sometimes causes the program to end. Seeing that, the youth council in consultation with the church board quickly makes those provisions. It became the time for body fitness. Rediger (1999) emphasizes the relevance of "integrating fitness of body, mind, and spirit as a move toward fulfillment of personhood and calling" (p. 102)

\section{Family-Based Youth Ministry}

Children tend to reflect their parents' thinking patterns, religious values, and attitudes about social behavior. They agree with their parents' lifestyles in social attitudes towards others and even in beliefs (Dudley, 1995, p. 24). Research reveals that parents have the power to model and strengthen the socialization of their children, especially in 
the primary years. Margaret and Roger Dudley (1995) say, "Young people tend to have offspring who are more traditional than their peers, although the youth are less traditional than their parents (p. 23).

In that way, parents are more influential in the young people's own thinking and the decisions they make about their lives. Even though the influence of peers is significant on adolescents' values, the parents' influence is still stronger. Another study declares "that in the areas of values and beliefs, parents are more important than peers (Lamport, pp. 1990, 24-27). Many people in the church recognize that their emotions, relationships, and spirituality are reflected from their parents and transfer them over to their children. Young people often find themselves doing the very things their parents did. Their character was already trained without specific lessons from their parents. We cannot afford to ignore the parental values and beliefs given to their children (DeVries, 1994, p. 78, 79). Thus, because young people are inclined to embrace the values and beliefs of their parents, as long as the parents firmly hold "the beliefs and values of a Gospel-oriented faith, the children will choose them (Strommen \& Hardel, 2008, p. 84).

\section{Summary}

The advancement of youth ministry is not limited to the confines of church alone. The larger picture of getting in touch and giving meaning to their lives can also center at recreational spots. Too many Christians consider games for the youth as waste of time. They act as if they have not laughed for many years. Playful interaction is a convenient strategy that binds the youth and adults together. We are encouraged to play games, because God commanded us to rest from work, to break the pattern of work and its grips on our daily lives, schedules, and thinking. The Bible says, "There is time for everything . 
.." (Ecc 3:1-4). It is easy to reach the young people where they are and lead them to the unknown. God knows that there is a dimension of human personality that better understands and feels the spiritual realm when elements of the physical world are used to teach spiritual concepts, however simple the illustrations may be. It is evident that through games, the principles of the incarnational model are elevated. Young people are connecting not only with their parents, but also with their friends. 


\section{CHAPTER 6}

\section{REPORT, SUMMARY, CONCLUSION, AND RECOMMENDATIONS}

\section{A Brief Project Report}

The philosophy behind any ministry should be thoroughly based on biblical revelation. That means our understanding and practice of youth ministry should be carefully modeled on the incarnation. When we accept the salvation offered us in Christ, we are saying "yes" to the invitation to become like Him. As Christians, we are to be remolded into the image of the perfect humanity of Jesus Christ (Eph 4:13). In the same way, we should strive to pattern our endeavors after His original, pioneering, pace-setting ministry, which is demonstrated in the incarnation (Acts 20:24). There is a higher, though more difficult calling which alone qualifies as genuine youth ministry, consciously deriving its sanctions and principles from the incarnation.

To do a better youth ministry we must enter the world of the adolescents just as Christ entered ours. Proper youth ministry cannot be at a distance. Stevens (1985) maintains that "we must become accessible to them by intentionally placing ourselves in the midst of their subculture" (p. 37). In the same way as Jesus moved close to touch and be touched, we must not allow culture to create a deliberate distance from young people. We must make contact with the youth and help them to a focused direction in their Christian journey (2 Cor 4:4-11). Adults, parents, pastors, and church elders must be 
willing to go to their campuses, visit them in their homes, and attend their games. Just as God could use some dedicated youth in both Old and New Testament periods, His arms are open to modern young people to advance His cause.

\section{Summary}

I have divided this section into three phases. The first phase deals with the findings of the research. The purpose has been to identify the participation of youth in ministry and to apply its principles in local church situations.

The second phase shows that the Scriptures contain many principles of the incarnational model which were demonstrated in the life of Jesus. There have been several instances where young people had the privilege of working for God. The Old Testament shows that many young people were engaged for special duties on behalf of God. Jeremiah was one whom God called in his prime and set him over the nations and over the kingdoms to root out, pull down, destroy and to throw down, but also to build and plant (Jer 1:10). As a youth, Jeremiah stood alone, declaring God's messages of doom, announcing the new covenant, and weeping over the fate of his beloved country.

Training was given to certain young individuals in the Old Testament and New Testaments. For many years Joshua was commander-in- chief for the army of Moses, and later became the leader of Israel. Daniel was a faithful young man in the courts of the Babylonians whom God used to reveal His majesty. Though Jeroboam was a wicked king, yet Solomon trusted him and made him leader of the construction job. Though there were many signs of inexperience among the youth of old, God still found in them a better reason for ministry. They participated in various forms of ministry. The principle is relationship, in which adults worked for them to watch and worked with them. The youth 
then worked with the adults, and they now worked without the adults. This means that as long as they were involved, they were also equipped. In fact, they were not trained in order to be involved. This principle also shows that the training came in the form of involving them by watching, experiencing and doing. When two groups do not know each other and do not get along, focusing on a subject or activity outside the area of. concern allows them to get acquainted and get over their ignorance. This is a Biblical approach of incarnation that Jesus demonstrated in the foot washing (John 13).

The third phase deals with emphasis on Christ's servant-leadership role which should be an approach to youth ministry. Christ's principles were illustrated in OT times where Moses was advised to share leadership. Jesus called, mingled, trusted, trained, and empowered. Humility was not only illustrated in the incarnational model, but it also showed that ministry was also present, wholistic and participatory. The principle of not counting himself equal with God (submission) was the entire ministry of servantleadership. He tapped all resources for some causes and at the time, demonstrated that ministry was not a position but a service. The greatest principle outlined in Old Testament ministry is being called to serve. To Jesus, culture was not a criterion to ministry. Where culture did not conflict with God's requirement, he had no problem of obeying it. However, He opposed culture when it became a stumbling block to human salvation. A practical application of the incarnational model ministry of Jesus is exemplified in youth ministry when adults and youth work together, when parents and their children join together in play, study, and evangelism. When adults and youth listen to each other with respect and are willing to risk trying a paradigm shift by empowering youth to become leaders, they will see results that will carry over into eternity. 
From my study of the Scriptures, I saw that the roles of youth are indispensable. There is a theological foundation for the involvement of youth in ministry, and the incarnational model is there for us to follow. According to a Valuegenesis study (Gillespie, 1982), although some youth participate in church programs, very few are active in developing their talents. Their needs are often ignored due to cross-cultural limitations, autocratic leadership, and the self-interested approach of adult leaders. Ultimately, the youth come to church and engage in activities that benefit the entire church. Parents and church leaders meet with the youth and discuss with them some achievable programs. Simply sending the youth out alone to serve is not a good strategy. Experiencing work together gives an additional opportunity to develop a trusting relationship with the youth. A recent study (Hopkins, et al., 2009, May) found that when youth have trusting relationships with a key adult, they are at a lower risk for dangerous behaviors (pp. 70-73). Gradual studies with young people will be a source to implement the incarnational model success fully. Gradually the church understood both the Old and New Testament examples of youth ministry, which consisted of calling, involving, training, and empowering for a firm theological foundation of youth ministry. These principles were at the heart of the Bantama Church paradigm shift that took place under my leadership. These results are possible when a church group supports the biblical idea of total involvement of youth.

\section{Conclusion}

There is always a harmful effect of cultural reasoning, which has no biblical foundation. Preserving a cultural heritage is not wrong since the Bible was written in a cultural environment. There are equally rich elements in the Asante culture whose impact 
can lead the youth into a sound Christian maturity. Its viewpoint needs to transform the youth to a sound theological maturity. Through the merge, the young people are relating to their parents, adults and church leaders. The church's desire to have better leaders for the future church is being attained daily. The youth are not only participating in church activities but are also channels for their peers to know God.

The Incarnational model closes the wide gap of cultural suppression on the youth, making them partners together in progress. The effect of the incarnational model is creating an atmosphere of change in the hearts and minds of the youth and adults. Where there had been violence, there is now peace. Spirited passion is replaced by the passion for Holy Spirit. The church leaders, parents and other adults have found the truth of reconciliation. Relationships do not liberate the youth from honor and respect due their parents and church leaders. Having understood and implemented the principles of the incarnational model, they are experiencing change. This change has been effective as long as this Biblical incarnational model is practiced. The concept that cultural values and beliefs can shape the youth depends on allowing the Bible to take its precedence. It is this way that the youth will grow in the fear of the Lord.

The first chapter dealt with the project/dissertation outline. The second chapter presented the theological foundation of the youth and their ministry. In that section, I explained my brief personal history, consisting of my temperament, personality type, spiritual gift, leadership/interaction style, spirituality web, task type reference, and present ministry situation. God has shaped me in my spiritual journey and my understanding of theology. I endeavored to live up to a standard where my theological viewpoints will not only be heard but will also be visible in my daily activities. This has 
been the reason why I delved into this aspect so as to deepen how people will understand the nature of God as He deals with them.

The third chapter presented the literature review which focused on the cultural context of the Asantes and their major behavioral problems. Power and leadership authorities within the Asantes have erupted in the church. This has disintegrated the interest of the youth because they are not part of the process of witnessing. Thus, there has been the need of a radical model to straighten the issues. The concept of the incarnational model did not evolve without controversial debate. However, the primary issue of the incarnational model centered on humility and acceptance as once demonstrated by Jesus (John 13).

The fourth chapter developed and expanded the incarnational model based on the Messianic prophecies in the Old Testament canon (Micah 5:2, Isaiah 53) which was clearly, revealed in the New Testament era (Matt 1:23; Luke 2: 11; Phil 2: 6-8; John 1:14). As a part of this model, a biblical based training for the parents/leaders and youth were held at different times in different locations. A clear strategy for the model was presented in the training with an apparent plan of action and timetable. The purpose of the incarnation model was to heighten the zeal of the youth by calling, training, and empowering them to participate in ministry. Young people want to be part of the church that cares and involves them.

\section{Application of Incarnational Model}

The basic reason why I chose the incarnational model was to demonstrate to the Bantama Church that they could pray and study to come out with other models that will enhance youth ministry. Youth ministry in our churches must exist not for social fun only 
but have spiritual programs that will reflect calling, involving, training, and empowering the youth for ministry. Leaders should involve the young people as a means of training them. They need to know that the principles of servant leadership, as Weems (1999) said, "Connects with the actual human needs of all people" (p. 13). The proposed incarnational model should outline the same principles in both the Old and New Testaments that translate the model into reality. According to Goleman (2002), "changing habits is hard work ... whenever people try to change habits of how they think and act; they must reverse the kind of that habit that resides in them" (p. 116). To become partners in the mission of the church, young people need to learn how to verbalize their faith, to put into words what they think and feel. Once feelings and concerns about their relationship with God have been conceptualized into words, they are able to deal rationally with matters of faith (Menton and Hardel, 2008). Making a lasting change requires a strong commitment to a future vision, especially during stressful times or amid growing responsibilities (Goleman, 2002). The incarnational model involves giving all to gain all the young people (Matt 10: 39, italics supplied). With this norm, adults and young people give all they have for a youth ministry that is vital, strong, lasting, and Christ centered, one that grows out of need and one that ministers to that need through people (p. 101). No single model of youth ministry should automatically be applicable in all situations. My suggestion for involving young people as part of training skills in chapter five is to reconcile them and the adults. This can be modified depending on the culture, time and situation of the ministry for young people in the future.

Many examples in the lives of some young people are cited who lived for God and could work to his glory. The experience of the life of Joseph in Egypt should be a 
focus as leaders show reconciliation with the young people. The adults must consider that the value of worship is expressed by participation. Adults can work together with young people when they are connected with them. The church of God must continue to exist and progress as young people and adults team together for that cause. With that in mind, the youth will definitely play a role in ministry as predicted by Joel (Joel 2:28-29).

The next session is a presentation of practical recommendations of the principles of the incarnational model which comes in three parts. The first part addresses problems that the Bantama Church is facing in the need of an incarnational model. According to Myers (1983), models are not just putting programs down and pasting them on the walls, then leaving them untouched. Models must be organized in such a way as to provide a sound and healthy ministry (p. 279). Old models have played tremendous roles in youth ministries; pastors and youth leaders can borrow from those experiences to build new models. The young people are watching, experiencing, and listening to new models from different sources. To meet their needs, our leaders should open up to their suggestions and involve them in decision-making process. Youth ministry models will demonstrate relationships and humility among the young people if it is biblically based. Therefore, the incarnational model must connect church leaders, youth leaders, and pastors of the young people.

The second addresses the importance of creating practical future youth ministry models which should be biblical. Cultural values and beliefs that will enhance the models cannot be overlooked; however, the Bible should be the foundation. If leaders are distracted from the goals ahead of the young people; the incarnational model must remind them of their responsibilities. In this new highly competitive age, leaders need to act out 
of love and dedication to facilitate success.

\section{Challenges Facing the Bantama Church}

The Bantama Church is the nucleus of all the churches of the Conference in terms of funding, membership and role of the youth. The youth are growing and many are excited by their participation and the level of reconciliation seen within their homes and the church. They need a full time youth pastor to take their responsibilities and plan with them. Success is not determined by fancy programs, attracting huge crowds with entertainment because they do not change the youth. Youth parades that attract applause, good songs, inspiring drama cannot be ruled out completely in youth ministry, but they are not everything for the youth. Ministry that may have lasting effect on the lives of the youth is the one that calls and trains to participate. This offers all the tools that are needed for growth, and then matures the people. This kind of ministry becomes a foundation for the youth and produces quality leaders and youth groups. Whenever there is no unity in a church, its growth becomes obstructed. For the purpose of advancing the cause of God, people being won must be Christians and not people filling the pews of the church.

Church members should be emptied of attitudes of selfishness and create chances for other people to build faith in God. Carl Roger (1995) said, "The only person who is educated is the one who has learned how to learn and change" (p. 78). Parents and adults are responding positively to the several workshops and seminars and they are allowing the youth in their arena. Many parents are accused by traditionalists of engaging the youth. The Bantama Church Board needs to educate the church about the incarnation model. It is only when principles of the incarnation model are embraced that any ministry can progress. 
When the youth are grouped together for their own church activities, there should also be an exchange program with the adult church. This will decrease misdirection of programming, and instead help them to develop their talents. The common and constant complaint will be investigated and resolved and a relationship will be maintained among different ages in the church. The challenges should open chances for the pastor, church leaders, and youth leaders to work thoroughly for their growth. The danger of not sharing with others outside the church will not constitute a living church. The youth will share the joy of sharing their faith with others as they witness for Christ. As they see themselves outside the corners of the church, visiting, praying, and teaching the gospel to their peers, they will be healthy and spiritually alive.

\section{Recommended Youth Ministry Model}

Youth ministry should begin with an executive level called a Youth Council. This is a small group of adults and youth who oversee the youth ministry to assure that the overall ministry goal is being met. This group is comprised of the pastor, youth minister, and two or three volunteers, a representation of men and women who have had experience working with young people. It is important that the youth council thoroughly understand and support the activities of the youth ministry. These people will be the objective observers.

They perform several important functions to ensure the ongoing success of the youth ministry. Some of the vital roles of the youth council include the following:

1. Supervision. They serve as a guide for the planning committee, and they keep in close touch with the primary person responsible for youth ministry. It is also part of their duty to assist the adult workers as they help to keep the young people in focus. 
2. Resources. The adults in the youth ministry carry the important responsibility of supplying teenage decision-makers with options and resources.

3. Training. They provide training for the adult youth workers, and for the youth who lead other youth.

4. Evaluation. They observe the process of the youth ministry and provide suggestions for improvement, interpreting the youth ministry to the congregation.

The church leaders, parents, and the entire church become dismayed if the youth ministry's successes and failures are not carefully interpreted to them. This is often their role.

It is worth the administrative team's efforts to make the youth and their ministry program very noticeable to the entire congregation. Schultz \& Schultz (1987) claims, "Education is always the first step toward committing the church to strengthening itself through greater youth ministry visibility (p. 73).

\section{Teamwork}

The Scriptures give several approaches to teamwork. The Old Testament's most powerful example was Moses. With all his responsibilities related to leading the people of Israel, he was advised to share leadership among his people (Exod 18:18). The solution that Jethro taught was basic delegation, a process of involving all. Another similar example is Jesus and the twelve disciples. By spending a portion of His active ministry training these men, Jesus prepared them for ministry and the future. Teamwork is an effective means of encouraging the youth's participation because the Lord has given them spiritual gifts as well (Rom 12:4 -5). The incarnation model of Jesus demonstrates this biblical concept. The church becomes ineffective when ministry is conducted 
independently. Understanding that there are different gifts, different perspectives in ministry and different abilities will help facilitate the acceptance of the different ways people look at ministry. The nature of youth work, with its multiplicity of needs and broad-ranging responsibilities, demands a team.

To pull together the most effective team for ministry, there should be the search for people with different spiritual gifts. These diverse gifts will provide a basis for making suggestions from different perspectives. Going through this process will help identify strengths and weaknesses and will contribute to an acceptance of changes.

\section{Develop Statement of Purpose}

The statement of purpose suggests future orientation. It is forward focused. It is an ideal and unique picture of the future that produces passion. It provides an answer to the question, 'where are we going?' It then makes clarification of purpose possible (Bell, 2003, p. 41). Fields (1998) says, "Unless a driving force behind a church is biblical, the health and growth of the church will never be what God intended" (p. 45). A clear purpose of the statement with Jesus as the point of reference will help to make sense of programs, utilize workers more effectively, and provide directions for spiritual maturity for the youth. A clear direction will manage conflict in ministry. It should be short and clear but should be action-oriented. The statement must be measurable, so that the church can measure their achievements, strengths, and weaknesses. It will show a clear route to a destination. Bell (2003) further states that developing a shared vision involves people that represent the diverse constituency (p. 46). 


\section{Evaluation}

Evaluation can be categorized as a biblical command. By understanding and applying the principles of the incarnational model of ministry, the Bantama Church has related well with the youth. To know how their relationships with the youth have influenced their activities demanded evaluation. Evaluation needs to be interlocked with learning effectiveness. With evaluation, the church has realized whether or not they have met the needs of the youth. As the church continues to evaluate its program, it becomes healthy. The youth council and all the committees of the youth should account for their stewardship to the church board. The youth council and its subsidiary committees had a particular date to render their stewardship. Members of the board presented questions for clarification to presenters and made sure that they were satisfied. Another date for a business meeting was arranged when evaluation papers were distributed to the entire membership. A committee was established to read the evaluation based on youth evangelism, participation in prayer on Sabbath morning, and all other activities that were held. In their findings, they commended the youth, elders, and the entire church for their meritorious work. They also provided suggestions to the church board for future programs. 
APPENDICES 
APPENDIX A

ORGANIZATIONAL CHART 
GENERAL LEADERS OF BANTAMA YOUTH

Youth Pastor

Kwasi Owusu Ansah

Youth Leader

Secretary Treasurer

Kwame Wiafe

Mary Mensah

Associate Leader

Beatrice Adiyiah

Associate Treasurer

Agyeman Prempeh

Organist

Akwasi Nnuako

Social Leader

Kofi Wiafe

Sponsor

Adjei Sarkodie 
APPENDIX B

YOUTH COUNCIL EXECUTIVE BOARD 
John Amankwaa

President

Ohene Kodua

Vice President

Peter Kwasi Oduro

Treasurer

SS Leader Evangelism
Isaac Agyeman

Secretary

Barbara Boakye

Asst. Secretary

Social Activities Leader Church Elder 
APPENDIX C

YOUTH PLANNING PROCESS 


\section{YOUTH PLANNING PROCESS}

The following are suggestions that came from the study of the principles involved in setting up a youth ministry for the youth of the Bantama Church:

Begin With a Group: In practical terms, group means the young people that you have been asked to work with, or have been challenged to work with.

Assess their Needs: This is most quickly achieved through listening and interacting with the young people, comparing the objectives and whether or not they are being met.

Choose Objectives to Meet Those Needs: Work with the youth in identifying and prioritizing their goals and select objectives.

Develop Strategies: Once the gaps between the objectives and the actual experience have been clearly identified, then an action plan needs to be developed.

Identify and Use Available Resources: People constitute one of the best resources for youth ministry. Some individuals within the church may be able to meet the identified needs. People from outside the immediate group with expertise should be seen as a valuable resource.

Schedule Evaluation: Weaknesses and strengths should be monitored and critically measured against the desired objective. To admit failure is not a sign of weakness but rather maturity. Evaluation will reveal that sometimes it is necessary to start again. 
APPENDIX D

INTERVIEWS WITH BANTAMA CHURCH PASTOR,

YOUTH LEADERS, ELDERS, PARENTS

AND WITH YOUTH 


\section{INTERVIEWS WITH BANTAMA PASTOR}

\section{SECTION I}

Demographic

1. Gender

a) Male

b)

Female

3. Marital Status

a) Single

b) Married

c) Single

4. Education

a) Senior Secondary School

b) College

c) University

5. Identify yourself

a) Member of AY

b) Non-member

c) Visitor

\section{SECTION II}

General youth questions

Give a brief answer. Give "Y" for Yes, "N" for No, "NA" for Not available or "ST" for Sometimes, where applicable.

5. Are you full time pastor of this church? $\underline{\mathbf{Y}}$

6. What is the youth membership of the church? pii (a lot of them)

7. Do the youth attend Sabbath worship frequently? ST

8. According to your answer earlier on, you have about 17 churches as a district pastor. $\underline{Y}$

9. Are you also church pastor for Bantama Church?

10. And are you the youth pastor for this large youth membership in Bantama Church?

$\underline{Y}$

11. Pastor, are you able to work in all these churches and still be a youth pastor? oho ne asem no (that's the issue) 
12 Do you have some people helping you in Youth Ministry? enve pii de (not that much)

13. Do you personally as a pastor have any problem of involving the youth in leadership? woye nkwadaa (they are kids)

14. Does Bantama Church involve the young people in their own youth activities? daabi (not at all)

15. What is the cause from engaging them into church programs? woye nkwadaa (not matured)

16. Beside the youth leader, do you have young people representation at the church board? daabi (N)

17. What roles do you commonly see the young people performing at camp meetings and other social activities? wosi apata (pitch tents)

18. Do the young people freely communicate with you as a pastor? wo mo mma (they don't come)

19. Do they frequently visit with you at your office or home, etc? koraa (not at all)

20. Have you realized the need for the youth to participate in programs that are unduly controlled by adults? yen haw no no (it's our problems today)

21. How often do you visit their programs? dakro dakoro bi (once a while)

22. Are you aware about how programs of the youth come about? $\mathbf{N}$

23. Is it possible that the young people can freely share their ideas with the adults some day? hmm enve seisei (well, not now).

24. Does Asante cultural philosophy have a place in Bantama Church?) Dodo (too much 
25. Do the adult church members feel it is not respectful to merge the youth with their parents? $\underline{Y}$

26. How do you attempt to suggest youth participation in the Bantama Church board meetings? $\underline{Y}$

27. Do you have hard time with the elders as you make such attempt? paapaapa (very well)

28. Have you noticed that many of youth problems can be assigned to their ineffectiveness? $\underline{Y}$

29. Do you think their meetings are producing better Christian experience in their lives? ST

30. Are the youth opting for a change in Youth Ministry? dabiara da (all the time)

31. Do you intend to suggest for a complete Youth Ministry church at Bantama? 32. Have you sought for a full time Youth pastor? $\mathbf{Y}$ 


\section{BANTAMA CHURCH ELDERS}

\section{SECTION I}

Demographic

1. Gender

a) Male

b) Female

3. Marital Status

a) Single

b) Married

c) Single

4. Education

a) Senior Secondary School

b) College

c)

University

5. Identify yourself a) Member of $\mathrm{AY}$

b) Non-member

c) Visitor

Give a brief answer. Give "Y" for Yes, "N" for No, "NA" for Not available or "ST" for Sometimes where applicable.

\section{SECTION I}

General questions

6. Do you regularly visit the youth in their meetings? $\underline{\operatorname{Daabi}(\mathrm{NO})}$

7. Do you know the membership of the young people in the church? Menim (NO)

8. If someone asks you about the level of youth participation in your church programs today, will you say it's ok? $\underline{\text { Kakra (a little) }}$

9. Who do you think the youth will run to when they are in danger, are sure they will come to any elder? Enye won nyinaa (not all of them)

10. How often are reviews done concerning the spiritual growth of these young people?

\section{$\underline{\operatorname{Koraa}(\mathrm{NA})}$}

11. Have you been hearing about some conflicts the young people have with their parents over attending youth camps? $\underline{\operatorname{Paa}(\mathbf{Y})}$ 
12. Do you see many of them at worship on Sabbath and in any other worship days? Nye dabiara (not always)

13. Do the youth go to their meetings to study the Word of God? Menko ho bi (I do not join them there)

14. How many elders have Bantama chosen to supervise the activities of the youth? Yeni $\underline{b i \text { (we don't have) }}$

12. Do you consider Bantama Church having successful Youth Ministry?ah! kakra (well, somehow)

13. What is your expectation for the spirituality of the young people? Ye bo mpae ama won (praving for them)

14. How often do you involve the young people in your visitation plan? Wonva won (hard to have them)

15. How many young people attend adults' board meeting? Ebi ni ho (NA)

16. Are you (elders and church pastor) responsible for casting vision for the youth? Aane efiri se wove nkwadaa (ves, because they are kids)

17. Will you accept the views of the youth if they disagree with the adults but that may help them? Daabi (NO)

18. Do you have a future plan for a meeting place for the youth? Nye seesei (not now) 19. Do you think the young people and the adults can ever work together? Ebekve (it will twke time) 


\section{Home Devotions and Social Activities}

20. Are you aware if the youth are meeting with their parents in home devotions? Menim

\section{(I don't know)}

21. Do you believe that if the youth do not play any role in the church, it can also affect their devotions with their parents? Daabi aden ntira (NO, WHY)

22. Don't you think that the youth are often suppressed by not being part of decision making process? Daabi (NO)

23. Do parents allow their children to attend social activities, like camp retreats, youth camps, etc? Eve den (IT'S TOUGH)

24. Though the youth live with their parents but do they relate well as people being trained to carry future responsibility? Eye abusua biara asem (it is left to every family to decide)

\section{PARENTS}

\section{SECTION I}

Demographic

1. Gender a) Male b) Female

3. Marital Status

a) Single

b) Married

c) Single

4. Education a) Senior Secondary School b) College c) University

5. Identify yourself a) Member of AY b) Non-member c) Visitor 


\section{SECTION I}

\section{General questions}

Give a brief answer. Give "Y" for Yes, "N" for No, "NA" for Not available or "ST" for Sometimes where applicable.

6. Do you regularly visit the youth in their meetings? daabi (N)

7. Do you know the membership of the young people in the church? daabi $(\mathbf{N})$

8. If someone asks you about the level of youth participation in your church programs today, will you say it's ok? menim (I don't know)

9. Who do you think the youth will run to when they are in danger, are sure they will come to any elder? entaa nsi It doesn't happen always)

10. How often are reviews done concerning the spiritual growth of these youth? dakoro, dakoro bi (once a while)

11. Have you been hearing about some conflicts the young people have with their parents over attending youth camps? bebree kwa (many times)

12. Do you see many of the youth at worship on Sabbath and in any other worship days? woba na wontra nkosi awie (they come but don stay until worship closes)

13. Do you think the youth go to their meetings to study the Word of God? mentaa nkoho nti menim (I am not sure because I seldom visit them)

14. How many elders have Bantama Church chosen to supervise the activities of the youth? ebi ni ho saa (none)

12. Do you consider Bantama Church having successful Youth Ministry? ebia (perhaps) 
13. What is your expectation for the spirituality of the young people? ye dwene ho

\section{(thinking about it)}

14. How often do you involve the young people in your visitation plan? koraa (at all)

15. How many young people attend adults' board meeting beside the leader? ebi nni ho (none)

16. Are you (elders and church pastor) responsible for casting vision for the youth? viw, yen na yenim dee eboboa wcn (we know what will be good for them so its our

\section{responsibility)}

17. Will you accept the views of the youth if they do not agree with the adults but yet may help them? yehwehwe mu kye (we analyze for long)

18. Do you have a future plan for a meeting place for the youth? enye seesei (not now) 19. Do you think the young people and the adults can ever work together? se nkwadaa no bre won ho ase de (if they humble themselves)

Home devotions and social activities

20. Are aware if the youth are meeting with their parents in home devotions? Beve den na yahu (how can we know)

21. Do you believe that if the youth do not play any role in the church, it can also affect their devotions with their parents? eno de won papa ne won maame adwuma (that's their parents' responsibility)

22. Don't you think that the youth are often suppressed by not being part of process of decision? kae se wove nkwadaa (remember that they are kids) 
23. Do parents allow their children to attend social activities, like camp retreats, youth camps, etc? dabi eferi se mpayinfo no ka se wobesei (no, because he parents believe their kids will get out way).

24. Though the youth live with their parents but do they relate well as people being trained to carry future responsibility? Asem no no (that's is the issue).

25. Do you accept their leadership anyway? Dabi, wonnim se woye nkwadaa? (No, don't you know they are kids?)

YOUTH

SECTION I

Demographic

1. Gender a) Male

b) Female

2. Age a) $18-20$

b) 20-22

3., Marital Status a) Single b) Married c) Single

4. Education a) Senior Secondary School b) College c) University

5. Identify yourself a) b) Member of AY b) Non-member c) Visitor

\section{SECTION II}

Questions on Worship.

Give a brief answer. Give "Y" for Yes, "N" for No, "NA" for Not Available or "ST" for Sometimes where applicable.

6. Are you a baptized Seventh -day Adventist Christian?

Y


7. Do you attend Sabbath worship often? $\mathbf{N}$

8. Do the youth participate in church worship programs? NA

9. What specific roles do the youth play in worship programs? NA

10. Are the youth recognized of being potential to carry out responsibilities? daabi (no)

11. What do the youth do during Sabbath school lesson study? Wotie nkoa (just listening

12. Have you observed that many of the youth walk around the church during Sabbath schools time? $\underline{Y}$

13. During worship do the youth stay in the church to listen to the ongoing activities?

ST

14. Why do you think the youth linger around during worship periods? Efirise venve hwee ntira (Because we don't do anything)

\section{Educational questions}

15. Do many of the youth at Bantama Church go to school?

16. I know Bantama Church has school; do some of the youth go to the church school? bebree (many)

17. Does the school offer programs that allow the youth to participate? daabi (no)

18. Do you specifically have Adventist Youth in the school? daabi (no)

19. Are the teachers in the school interested in youth programs? nve pii (not much)

20. Do parents visit you in some of your youth programs in school? koraa (at all)

21. Has there been a time when your parents who attended Teacher- Parents' meeting commended you on your spirituality or just on academics? adesua ho nsem nkoa (just on academics) 


\section{Youth meeting questions}

22. Do the youth have permanent place for meeting? asore dan koro no ara mu (in the same church premises)

23. Is that place a particular meeting venue or you keep changing from time to time?

\section{yesesa (keep changing)}

24. Do the youth usually attend youth meetings? ST

25. Do you have consistent youth leaders? $\underline{N}$

26. Do they provide you with adequate information about Youth Ministry? N

27. Do they lead in all programs at a meeting? $\mathbf{Y}$

28. What other functions do you perform as youth members during your meetings? yetaa

\section{kosua aben bo (mostly learning to play flutes)}

29. Do many of the adults visit you at your meetings? $\mathbf{N}$

30. Can you think of a time when any of your parents visited you at your meetings? $\mathbf{N}$

31. Who comes up with your programs? mpayinfo no (elders)

32. Do your parents freely allow you to go to youth meetings? oho ne ntokwa no (that's where the problem starts)

33. Do you enjoy your meetings?_ST_

Questions on Cultural influence on the youth participation.

34. Who/What prevents you from attending youth programs? mpayinfo hye bibiara so (adults control everything)

35. Do you like to play a role in church programs?

36. The rate at which the youth attend youth camps, retreats, and other social meetings is declining. Is that true? $\mathbf{Y}$ 
37. Do you share your experience with your parents, church leaders, and adults in your church? Daabi(no)

38. Do the adults easily accept your views?

39. Are you part of decision making process in Bantama Church? koraa (not al all)

40. In the Akan tradition, is it forbidden for the youth to lead? etaa si (it happens often)

41. Do you the adults in the church impose their decisions on the youth, even if it at their dislike?

42. Do you think there is healthy relationship between the youth and the adults that inspire the youth to participate in church programs? $\mathbf{N}$

43. Do you like this relationship to remain? $\mathbf{N}$

44. Many of your friends have already told me on telephone that the youth are inferior in the sight of the adults. For this reason they do not fit in any responsible position. Do you share that? De wove no kyere saa (what they do shows that)

45. Have you ever thought when you could be involved in church programs as a means to prepare you for evangelizing your friends? Enka ebeve me de (I would enjoy)

46. Do you feel comfortable in coming to church on every Sabbath? $\underline{\text { ST }}$

47. How often have you wondered why the youth cannot join their parents in worship? mpen pii (many times)

48. Do you expect to see a time when the youth and the adults will work together to hasten the coming of the Lord? $\mathbf{Y}$

Manner of interview:

All questions were written in English.

Interviewer spoke in Asante Twi dialect. 
All interviewees answered in Asante - Twi dialect.

Direct Asante - Twi answers appear immediately after each question.

Personnel interviewed:

Bantama Church pastor

Bantama elders

Some parents from Bantama Church

Young people

Symbol for comments

$\mathrm{Y}=$ Yes: Observation on how adults feel about the young people.

$\mathrm{N}=$ No: Extent of gap created by cultural beliefs and its negative impact on youth.

ST $=$ Sometimes: State of confusion within number of confused youth

$\mathrm{NA}=$ Not available: Inactive youth with no progressive comments.

Comments

1. Authoritarian leadership style

2. Cultural gap

3. Force

4. Fear

5. Non-participation

6. Misdirection

7. Rude

8. Quarrel

Due to my immigration status as FI, I was allowed to do email and telephone interviews. 
APPENDIX E

YOUTH MINISTRY RESOURCES 
YOUTH MINISTRY RESOURCES

ADVENTIST EDUCATION HELP LINES:

Andrews University: $\quad 1800-253-2874$

Atlantic Union College: $\quad 18002822030$

Florida Hospital College of Health Sciences: 1800-500-7747

Home Study International: $\quad 1800-394-4769$

L a Sierra University: $\quad 1800-874-5587$

Loma Linda University: · $\quad 1800-422-4228$

Oakwood College: $\quad 1800-824-5312$

Pacific Union College: $\quad 1800-862-7080$

Wala Wala College: $\quad 1800-541-8900$

SDA PlusLine: $\quad$ 1800-SDA-PLUS

Union College: $\quad 1800-228-4600$

Weimar College: $\quad 1800-525-9192$

ADVENTIST INFORMATION HELP LINES:

Adventist Information Ministries (AIM): 1800-253-3000

ADVENTIST YOUTH \& YOUNG ADULT MINISTRY HELP LINES:

Center for Youth Ministry Evangelism: 1 800-YOUTH-1800-68-8428)

Creative Ministry Resources Center: 1 800-272-4664

Family Matters: $\quad 1800-309-$ LOVE

Hancock Center for Youth Ministries: 1800-785HCYM (1800-785-4896)

Youth and Young Ministry Response Line: $1800-$ SDA-7738 
CHURCH COMPUTER/SOFTWARE RESOURCES

Apply Software Systems, Inc: 1800-932-7759

Bible Master: 1800-535-5131

Biblesoft: 1800-995-9058

BibleSource: 1800-925-0316

Christian Technologies: 1-800-366-8320

Christianity Online (American Online): 1-800-827-6364

CompuBible: 1-800-288-2044

Computer Source: 1-800-526-9166

Consistent Computer bargains: $1-800-342-4222$

DisKit: 1-800-323-7543

Growing Technologies: 1-800-490-GROW

HyperBible: 1-800-428-4385

Kingdom Computers: 1-800-488-1122

Logos Research Systems: 1-800-87-LOGOS

Group's MinistryNet: 1-800-447-1070

NavPress Software: 1-800-777-SOFT

New Bible Library: 1-800-222-0171

Online Bible: 1-800-243-7124

Oxford University Press: 1-800-451-7556

Quick Verse: 1-800-223-6925

SDA On-line (CompuServe): 1-800-260-7171

Venture Bible: 1-800-328-4648

169 
White Harvest Software: 1-800-318-7333

WordSoft: 1-800-933-9673

Your Track 4.0: 1-800-625-2388

\section{DRAMA MINISTRY/ ARTISTS/ PUBLISHER RESOURCE}

Baker's Plays: 1-800-8-ACT-NOW

Center for Creative Ministries: 1-800-610-9676

Contemporary Drama Service: 1-800-93-PLAYS

Covenant Players: 1-800-350-5719

Destination Players Christian Drama Company: 1-800-801-3992 ext. 9393

Destiny Drama Company: 1-800- SOUTHERN

Dramatic Publishing Company: 1-800-HIT-SHOW

Heuer Publishing Company: 1-800-950-PLAY

International Arts Ministry: 1-800-247-6440

One Way Street: 1-800-569-4537

Pioneer Drama Service: 1-800-33-DRAMA

Resource Publications: 1-800-736-7600

Willow Creek Drama Resources: 1-800-876-SEEK

\section{FILM/VIDEO/AUDIO/MULTI-MEDIA RESOURSES}

A Time to Speak: 1-800-453-5158

Adventist Communication Network: 1-800-ACN-1119

Adventist World Radio: 1-800-4AWR

American Cassette Ministries: 1-800-233-4450 
American Tract Society: 1-800-548-7228

Christian Family Video: 1-800-231-0095

Crown Ministries International: 1-800-433-4685

CYM Productions: 1-800-559-4781

Family Research Council: 1-800-225-4008

Vision Videos: 1-800-523-0226

Young Productions: 1-800-448-4812

Youth Leaders Only: 1-800-725-3300

\section{FUND RAISING/CLOTHING RESOURCES}

Coupon Coalition: 1-800-767-7718

CrossCap Inc.: 1-800-873-5911

CrossThreads: $1-800-436-3455$

Dutch Mill Bulbs: 1-800-533-8824

Evergreen Industries: 1-800-248-3048

Home Study International Press: 1-800-394-7746

Living Epistles: 1-800-635-3128

New Life Industries: 1-800-443-9523

Profit Potentials: 1-800-543-9793

Rocky Mountain Music \& Video: 1-800-808-0986

Show 'N Tell: 1-800-TELL

Truth Clothing: 1-800-683-78 


\section{REFERENCE LIST}

Abbott-Smith, G. (1937). A Manual Greek Lexicon of the New Testament, 3rd ed. Edinburg: T. \& T.

Adams, S. L. (2008). Servant leadership and the earth. Journal for Preachers, 31(4), 2933.

Anderson, R. S. (1979). A theology for ministry. In R.S. Anderson. (Eds), Theological foundations for ministry: Selected readings for a theology of the church in ministry. Grand Rapids, MI: Eerdmans.

Anderson, R. S. (2001). The shape of practical theology: Empowering ministry with theological praxis. Downers Grove, IL: InterVarsity.

Anderson R. S. (2005).Living in the world. In Theological foundation in ministry. Edinburg: T \& T Clark

Adu, B. (2003). The history of Ashanti kings and the whole country itself and other writings. London: Oxford.

Aoki, W., Engert, P.A., Turk, A.A., Wilson, R., Chen, J., \& Latu, E. (2000). Mentoring and the discipleship of adolescents: Research and applications to the church Journal of Psychology and Christianity. 19(4), 307-385.

Arnold, B.T. (2003). $1^{\text {st }}$ and $2^{\text {nd }}$ Samuel: The NIV application commentary from biblical text to contemporary life. Grand Rapids, MI: Zondervan.

Arzola Jr., F. (2008). Toward a prophetic youth ministryin urban context. Downers Grove: IVP Academics.

Atkinson, H. (1997). Ministry with youth in crisis. Brimingham, AL: Religious Education.

Austry, J. A. (2004). The servant leader: How to build creative team, develop great morale and improve bottom-line performance. New York: Three Rivers.

Ballard, P. (1999). Practical theology International Perspectives. Frankfurt am Main: Peter Lang. 
Banks, J.A. (1981). Education in the 80's. Multiethnic education National Association of the United States. An Arbor, MI: University of Michigan.

Barna, G. (1992). Finding a church you can call home: The complete guide to making one of the most significant decision. Ventura, CA: Regal.

Barna, G. (1993). Absolute confusion: How our moral and spiritual foundation are eroding in this age of change. Ventura, CA: Regal.

Barna, G. (1999). Third millennium teens: Research on minds, hearts, and souls of America teenagers. Ventura, CA: Barna Research Group.

Barna, G. (2000). Evaluating your church ministry. Ventura, CA: Barna research group.

Barna, G. (2003). Think like Jesus: Make the right decision every time. Nashville, TN: Integrity.

Barna, G. (2006). Twelve most significant religious findings, Retrieved August 12, 2009, from http://www.barna.org

Barna Group (1991). Today's teens: A generation in transition. Milwaukee, WI: Group.

Barna Research Online (May, 2001). Young people who attend church and are active and show lifelong effects. Retrieved September 16, 2009, from http://www.barna.org/cgibin/PagePressRelaese.asp?

Barber, K. (1990). Social learning theory. Lanham, MD: University of America.

Baron, R.A. (1983). Behaviors in organizations: Understanding and managing the human side of work. Boston, MA: Allyn \& Bacon.

Barth, K (1911). The place of theology. In Anderson, R. A. (1979). Theological foundation for ministry: Selected readings for a theology of the church in ministry. Grand Rapids, MI: Eerdmans.

Bauer, W. F., Gingrich, W.W., \& Danker, F. W. (1979). A Greek-English Lexicon of the New Testament and Other Early Christian Literature. Chicago, IL: University of Chicago.

Behm, J. (1977). Theological dictionary of the New Testament. Grand Rapids, MI: Eerdmans.

Bell, S. (2003). A time to serve: Church leadership for all the $21^{\text {st }}$ century. Lincoln, NE: Adventure. 
Benson, W. S. (1987). A theology of youth ministry. In Complete book of youth ministry. Chicago, IL: Moody.

Black, J. M. (1978). Leadership. New York: Harper and Row.

Black, W. (1991). An introduction to youth ministry. Nashville, TN: Word.

Black, W. (2003). Why and how should a church consider its teenagers. Retrieved October 6, 2009, from www.youthspecialties.com

Black, W. (2004). Youth Ministry that lasts: The faith journey of young adults for lasting faith, Journal of Youth Ministry, 4(2), 13.

Blackaby, H. \& Blackaby, R. (2001). Spiritual leadership. Nashville, TN: Broadman \& Holman.

Boahen, A. (1997). Ghana: Evolution and change in the nineteenth and twentieth centuries. Longmans: Green \& Company.

Boakye-Dankwah, G. (2000). Blow the trumpet: Africa Indian Ocean Division of Seventh-day Adventist Church evangelism handbook. Accra, Ghana: Advent.

Bogart, M. (1996).4 ways to build a better youth group. Newton, Kansas: Faith and Love.

Bonheoffer, D. (2001). Cost of discipleship. New York, NY: SCM- Canterbury.

Borthwick, P. (1988). Organizing your ministry. Grand Rapids, MI: Zondervan.

Borthwick, P. (1990). Feeding your forgotten soul. Spiritual growth for youth workers. Grand Rapids, MI: Zondervan.

Borthwick, P. (1996). Six dangerous questions to transform your view of the world. Downers Grove, IL: InterVarsity.

Borthwick, P. (1996). What is the state of youth ministry around the world? Journal of Christian Education and Belief, (16), 10.

Borthwick, P. (2000). Reviewing leadership: A Christian evaluation of current approaches. Journal of youth ministry. 6 (4), 2.

Borthwick, P. (2001). The youth builder. Grand Rapids, MI: Zondervan.

Borthwick, P. (2004). Hurts: Inside the world of today's teenagers. Kansas City, OR: Baker. 
Bosch, F. (1991). Transforming mission: Paradigm shifts in mission theology. New York: Orbis Books.

Briscoe, A. (1984). Youth becoming leaders. Nashville, TN: Convention.

Bromley, G. W. (1979). International standard Bible encyclopedia. Grand Rapids, MI: Eerdmans.

Brown, R. (1965). Social psychology. New York, NY: The Free.

Burns, J. (2001). The youth builder: Today's resource for relational youth ministry. Ventura, CA: Gospel light.

Burns, J. M. (1972). Complete book of youth ministry. Chicago, IL: Moody.

Burns, J. M. (1991). Leadership. New York: Harper \& Row.

Burns, J. \& DeVries, M. (2001). The youth builder: Reach young people, strengthen families and change lives forever. Wheaton, IL: Tyndale.

Burns, J. \& DeVries, M: (2001). The youth builder: Today's resource for relational youth ministry. Springfield, MO: Gospel light.

Buttrick, G. A. (1962). Interpreter's standard Bible encyclopedia. Grand Rapids, MI: Zondervan.

Buttrick, G. A. (1962). The interpreter's dictionary of the Bible. Nashville, TN: Abingdon.

Calvin, J. (1998). Calvin's commentaries: Jeremiah. (Electronic Ed.) Logos library system. Albany, OR: Agnes software.

Campolo, A. (1983). Ideas for social action. Grand Rapids, MI: Zondervan.

Campolo, A (2000). Having a heart of disconnected world: Loving like Jesus. In McDowell, J. (2000). Youth ministry handbook: Making connection. Nashville, TN: Word.

Carson, D. A. \& Guthrie, A. B. (1997). New Bible commentary: $21^{\text {st }}$ century edition, $4^{\text {th }}$ ed., Jer 1:1. Downers Grove: InterVarsity.

Carson, R. (1998). The edge of the sea. New York, NY: Houghton Mufflin Court.

Cartwright, L. (1962). The great commitment. St Louis, MS: Bethany.

Case, S. (1993). Understanding youth culture. Silver Spring, Md: North American Division of SDA Youth Ministries. 
Case, S. (2007). Shall we dance: Rediscovering Christ-centered standards edition. Riverside, CA: La Sierra University.

Cavalletti, S. (2002). The religious potential of the child 6 to 12 years old. Chicago, IL: Liturgy Training.

Collins, A. Y. (2007). Mark: A commentary. Minneapolis, MN: Fortress.

Collins, P. (1997). Champion strategy for doing ministry together. Journal of Youth Ministry, 7(1), 142.

Chadwick, H. (1991). Augustine, confessions, translated. Oxford: University Press.

Central Ghana Conference of Seventh-day Adventist Church (2003). Monthly statistical report. Received a copy from the Conference Secretariat on August 2008.

Checkoway, B. \& Schuter, K. (2003). Final evaluation of lifting new voices. Ann Arbor, MI: University of Michigan.

Christie, J. L. (2005). Best ever games for youth ministry. Loveland: Group.

Clapp, S. \& Cook, J. (1981). Youth workers handbook. Sidell, IL: Resources.

Clark, C., Senter III, M., Black, W., \& Malan, N. (2001). Four views of youth ministry and the Church. Grand Rapids, MI: Zondervan.

Coker, F. (1968): Today's youth: Closing the gap. Review and Exporter, 65(2), 76.

Coleman, T. K. (1995). The nature of adolescence. New York: Harvard University.

Collins, P. (2008). Youth ministry. Slat Lake, Fl: Xulon.

Cosby, M. R. (1989). Portrait of Jesus: An inductive approach to the Gospels. Louisville, KY: Westminister John Knox.

Creasy, K. D. (2000). An unexpected prophet: What the $21^{\text {st }}$ century can learn from youth ministry. Princeton, NJ: Princeton Theological Seminary.

Creasy, K.D., Clark, R., Rahn, D. (2001). Starting right: Thinking theologically about youth ministry. Grand Rapids, MI: Zondervan.

Creasy, K. D. \& Foster, R. (1998). The Godbearing life: The art of soul building for youth ministry. Nashville, TN: Upper Room.

Crenshaw, J. L. (1973). Samson: A secret betrayed, a vow ignored. Atlanta: John Knox. 
Csikszentmilhalyi, M. and Larson, R. (1986). Being adolescent: Conflict and growth in the teenage years. New York: Basic Books.

Danker. W. F. (2000). A Greek - English lexicon of the New Testament. Chicago, IL: University of Chicago.

Dean, K.C. (2000). An unexpected prophet: What the $21^{\text {st }}$ century can learn from youth ministry. Princeton, NJ: Princeton Theological Seminary.

Dean, K.C., Clark, R., Rahn, D. (2001). Starting right: Thinking theologically about youth ministry. Grand Rapids, MI: Zondervan.

Dean, K.C., Foster, R. (1998). The Godbearing life: The art of soul building for youth ministry. Nashville, TN: Upper Room.

Dela, B. (2009). Laudable: President Mills' gives youth opportunity in Government. Retrieved August 2, 2009, from ww.ghanaweb.com

Dettoni, J. M. (1993). Introduction to youth ministry. Grand Rapids, MI: Zondervan.

Devries, M. (1994). Family-based youth ministry. Downers Grove, IL: InterVarsity.

Dilulio, J. (2002). The three faith factors. Retrieved on February 16, from http://www.bookings.edu/articles/2002/fall_faithbasedinitiatives_diiulio.aspx

Dudley, R. (1995). A snapshop of Adventist parents. Journal of Adventist Education, (58), 24.

Dudley, R. L., and Gillespie, B. V. (1992). Which way to the future: Faith in the balance. Riverside, CA: La Sierra.

Dunn, R. R., Senter, M. (1997). Reaching a generation for Christ: A comprehensive guide to youth ministry. Chicago, IL: Moody.

Edudze, E. (2000). Hear the voice of Ghana youth. Transport report (mpg), Accra, Ghana.

El-Meligi, A. (2005). Leading starts in the mind: A human view of leadership. Atlantic City, NJ: World Scientific.

Erickson, E. H. (1968). Identity, youth, and crisis. New York: N. W. Norton.

Erickson, E. H. (2002). Childhood, teenage, and society. New York: NW Norton.

Ferguson, R. (1968). The Church ministry with seniors. Nashville, TN: Graded. 
Fields, D. (1998). Purpose -driven youth ministry: 9 essential foundations for healthy growth. Grand rapids, MI: Zondervan.

Fields, D. (2002). Your first two years in youth ministry: A personal and practical guide. Grand Rapids, MI: Zondervan.

Fitch, D. (2000). Christ, our righteousness. In Warner, A. R. (2002). Fulfilling all righteousness: The death of Jesus in Matthew. Theology and Mission, 29 (1), $12-$ 19.

Fitzgerald, L (2000). Following the steps of Jesus: Modeling. The International Journal of Psychology of Religion, 13(3)22.

Foster, R. (2009). Spiritual formation: Agenda. Christianity Today 53(1), 30.

Fowler, J. W. (1991). Stages of faith: The psychology of human development and the quest for meaning. San Francisco, CA: Harper \& Row.

Fowler, J. W. (1998). Ministerial/Evangelism Council: Youth department. North Pacific Union Conference of Seventh-day Adventists. Enumclaw, WA: A \& J.

French, J. R. P (November 2007). The pastor and power. Ministry, International Journal for Pastors.

Fynn, P. K. (October 2005). Christian Council of Ghana: Put country first. Christian Today. Retrieved on December 2009, from http://www.christiantoday.com/article/ christian.council.of.ghana.put.country.first/4169.htm

Gaebelein, F. (1991). The expositor's Bible commentary. Deuteronomy- $2^{\text {nd }}$ Samuel, vol. 3. Grand Rapids, MI: Zondervan.

Gallup Jr., G. \& Ericson, E. H. (2002). Childhood, teenage and society. New York: N. W. Norton and Company.

Gallup Jr., G. \& Poling, D. (1980). Search for America's faith. Nashville, TN: Abingdon.

Gane, B. (1993). Local leadership development in the local church. U.M.I Dissertation Services. Ann Arbor: Bell and Howell.

Gane, B. (1997). Building youth ministry: A foundational guide. Riverside, CA: Hancock Center.

Gant, J. (2008). Youth ministry. Nashville, TN: Abingdon. 
Garcia-Marenko, A. (Ed.). (2000). Youth ministry handbook and leadership training manual. Youth department, General Conference of Seventh-day Adventists. Boise, ID: Pacific.

Garrett, A. (1977). Yesterday's authors for books for children: Facts and pictures about authors and illustrators of books for young people, from early times to 1960. Kirkham, NJ: Gale Research.

General Conference of Seventh-day Adventists. (1990). Church ministries department, Discipleship. In youth ministry handbook and leadership training manual. Silver . Spring, MD: The Youth Department.

Ghana Government Statistical Services (2002). Census and population: Ghana's population 18million. Retrieved July 9, 2009. from www. Ghanaweb.com

Gibbs, E. (2000). Church Next: Quantum changes in Christian ministry. Downers Grove. IL: Intervarsity.

Gibson, H. N. (July 2000). Sexual assaults of young women as reported to Law Enforcement: Victims, incident, and offender characteristics. (Report No 7/00, NCJ 182990). (U.S. Department of Justice and Statistics).

Gillespie, V. B. (1982). Conversion and identity. (Sound recording). General Conference Ministerial Association, Silver Spring, MD: Adventist Media Center.

Gillespie, V. B. (2004). Valuegenesis: Ten Years Later: A study of two generations. Riverside, CA: Hancock Publication.

Gillespie, V. B. \& Donahue, M. (2005). Valuegenesis 2: Adventist Church in Canada: A study of influence of family, Church, and school in faith, values, loyalty and commitment of Seventh-day Adventist youth. Riverside, CA: La Sierra University.

Gillespie, V. B. \& Gillespie, J. A. (2001). Keeping the faith: A guidebook for spiritual parenting. Riverside, $\mathrm{CA}$ : Hancock.

Glenn, J. F. (2001, January/February). The benefits of learning: The impact of education on health, family life and social capital Harvard Education Letter, 4, 20-22.

Goleman, D. (2002). Primal leadership: Learning to lead with emotional intelligence. Boston, MA: Harvard.

Greenleaf, R. (1977). Servant-leadership A journey into the nature of legitimate power and greatness: Mahwah, NJ: Paulist.

Greenleaf, R. (2001). Servant leadership: A journey into nature of legitimate power and greatness. Mahwah, NJ: Paulist. 
Greenleaf, R. K., Hamilton, B., Beggs, J., \& Larry, C. S. (2002). The servant-leader: A transformative path. Mahwah, $\mathrm{NJ}$; Paulist.

Groome, T. H. (1988). Educating for life: A spiritual vision for every teacher and parent. New York: Crossroad.

Habermas R., Issler, K. D. (1992). Teaching for reconciliation. Grand Rapids, MI: Baker.

Hagberg, J.O. (2002). Real power: Stages of personal power in organizations. Salem, Wisconsin: Sheffield.

Harder, F. A. (2009). The developmental stages of Erick Erickson. Retrieved on February 7, 2010, from http:/www.learningplaceonline.com/stages//organize/Erickson

Harris, J. (2005). Notes on youth ministry. South Pacific Division, Seventh-day Adventist Church, youth department. Wahroonga, Australia.

Harris, R. L. (1981). Theological wordbook of the Old Testament. Chicago: Moody.

Hendricks, W. (1953). New Testament commentary: Exposition of the Gospel according to John: Grand Rapids, MI: Baker.

Herrington, J. T. (2003). The leader's journey: Accepting the call to personal and congregational transformation. San Francisco: Jossey-Bass.

Hershey, T. (1994). Young adults. Loveland: Group.

Hiebert, E.M. (1995). Incarnational ministry: Planting churches in bond, tribal, peasant, and urban societies. Grand Rapids, MI: Baker.

Holderness, W. G. (1977). Teaming up: Shared leadership in youth ministry. Louisville, KY: Westminister John Knox.

Holmes, U. T. (1980). A history of Christian spirituality: An analytical introduction. New York: Seabury.

Honeycutt, R. (1981). Jeremiah, the Prophet and the book. Review and Expositor, 78(3), 13,305 .

Hopkins, G. L., McBride, D., Tyner, S., Drumm, R., \& Kannesburg, W. (2009, May). Discovering healthy kids in healthy communities: Adventist Review and Herald, 186 (10), 16- 19.

Horst, B. \& Schneider, G. (1981). Evangelical dictionary of the New Testament, vol. 2. Grand Rapids, MI: William Eerdmans. 
Hwan Huh, J. (2001). Youth ministry strategies for Korean Seventh - day Adventist Church in the United States. Doctor of ministry dissertation, Andrews University, Berrien Springs.

Jamieson, R., Fausset, A. R., \& Brown, D. D. (1971). Commentary on Leviticus on Lev. 21:7: in commentary critical on the whole Bible. Oxford University. Washington D.C.

Jones, T. (2003). Soul prayer: Exploring spirituality and contemplative practices in youth ministry. Grand Rapids, MI: Zondervan.

Kamstra, D. (1990). A spiritual foundation through youth Gospel. Unpublished doctor of ministry dissertation, Fuller theological Seminary, Los Angeles, CA.

Keefauver, L. (1984). Starting a youth ministry. Loveland, CO: Groups.

Keirsey, D. \& Bates, M. (1984). Please understand me: Character \& temperament types. Delmar, CA: Prometheus Books.

Kenda, P. (2007). Rewired: youth ministry in all Age of IM and MySpace. Valley Forge, PA: Judson.

Kessler, E. (2004). Bound by the Bible. Jewish Christians and the sacrifice of Isaac. West Nyack, NY: Cambridge University.

Kettler, C. D. \& Speiddel, T. (2001). Incarnational ministry: In the presence of Christ in the Church, society, and family. Colorado Springs: Wipf \& Stock.

Koranteng-Pipim, S, (2006). Opening address. General Youth Council. Minnesota.

Kostenberger, A. F. (2004). John: Baker exegetical commentary on the New Testament. Grand Rapids, MI: Baker.

Kouzes, J. C. \& Posner, B. Z. (1995). How to keep getting extraordinary things done in organizations. San Francisco, CA: Jossey-Bass.

Kouzes, J. C. \& Posner, B. Z. (2007). The leadership challenge. River Street, NJ: Jossey Bossey.

Kroeger, O. \& Thuesen, M. (1989). Type talk: The 16 personality types that determine how we live, love and work. New York, NY: Bantam Doubleday Dell.

Kujiwa, S. A. (1998). Disorganized Religion. The evangelization of youth and young adults. Boston. MA: Cowley. 
Kyeremateng, K. N. (1996). The Akans of Ghana: Their history and culture. Kumasi, Ghana: Sebewie.

Lamport, M. K. (1990). Adolescent spirituality: Age of conversion and factors of development. Christian Education Journal, 10(3), 24-25.

Lawrence, E. A. (May, 2008). Building relationship through pastoral visits. Ministry: International Journal for Pastors.

Lee, W. (2008). The role of critical thinking in youth leadership praxis: A grounded theory Liberty University.

Letham, D. S. (1988). Biblical basis for youth ministry. Leicester: Intervarsity.

Lim, T. K. (1995). An introduction to Korean church. Philadelphia: Westminister.

Loewenstamm, S. E. (1980). Comparatives studies in biblical and ancient oriental literature. Kevelaer: Butzon \& Bercker.

Lucas; E. (2002). Apollos Old Testament commentary. Downers Grove, IL: InterVarsity.

Marcia, J. (1980). Identity in adolescent psychology. In Anderson, J. (Ed.). Handbook of psychology. New York: Wily.

Marcum, W. (2001). Deepening youth spirituality: The youth worker's guide. Nashville, TN: Abingdon.

Martin, R. (1988). Effective youth ministry: A congregational approach. Minneapolis, MN: Augsburg.

Maxwell, L. (1993). Becoming a dynamic youth leader: A guide for equipping youth workers. Lynchburg, VA: Church Growth Institute.

Mazrui, A. (2001). Pan-Africanism, democracy and leadership in Africa: The continuing millennium. Inaugural Abdulsalami Abu - Bakr lecture. State University of Chicago. Retrieved on September 15, 2009, from http://igcs_site/dirton6.htm

McCaskie, T. C. (1996). Surveys: The history, topography, people, and culture of Ghana. (Video) Graduation presentation at University of Cape Coast, Ghana.

McCaskie, T. C. (2007). Denkyira in the making of Asantes. The Journal of African History, 48(1), 1.

McDowell, J. (2000). Josh McDowell's youth ministry handbook: Making the connection. Nashville, TN: Word. 
McKenzie, J. (2000). Making change happen. The Educational technology Journal. $9(10)$.

McNeil, J. T. \& Ford, F. T. (1960). Calvin: Institute of the Christian Religion. Philadelphia: Westminister.

McNeil, R (2000). A work to heart: Understanding how God shapes spiritual leaders. San Francisco, CA: Jossey-Bass.

McIver, R. (2000). The four faces of Jesus. Four Gospel writers, four unique perspectives, four personal encounters: Nampa. ID: Pacific.

Menton, J \& Rahn, D. (2000). Contagious faith: Empowering student leadership in youth evangelism. Loveland, $\mathrm{CO}$ : Group.

Menton, P. \& Hardel, D, (2008). Passing on the faith: A radical model for youth and family ministry. Wynonna: St Mary.

Milavec, A. (1982). To empower as Jesus did: Acquiring spiritual power through apprenticeship. Lewiston, NY: Edwin Mellen.

Mounce, W. D. (1993). Analytical lexicon to the Greek New Testament. Grand Rapids, MI: Zondervan.

Mueller, W. (1999). Towards a youth ministry and its praxis in the urban context. Tyndale House.

Mueller, W. (1999). Understanding today's youth culture: Parents, teachers and youth leaders. Wheaton, IL: Tyndale.

Muller, K., Sundermeier, T. \& Bliese, R.H. (1977). Dictionary of mission: theology, history, perspective. Maryknoll, New York: Orbis.

Murphy, T. (1977). Programming with purpose: Developing process for programming Grand Rapids, MI: Zondervan.

Myers, W. R. (1983, Spring). On building models for youth ministry. Religious Education, 78(2), 279-282.

Nana Owusu-Kwarteng, W. (2005). Asante traditional leadership and the process of Educational change. Unpublished doctoral dissertation, Ohio State University, Athens, $\mathrm{OH}$.

Ng, D. (1984). Youth in the communities of disciples. Valley Forge, PA: Judson.

Northhouse, P. C. (2004). Leadership: Theory and practice. Thousand Oaks, CA: Sage. 
Nosotro, R. (2009). Deliver the Jews. Retrieved January 7, 2009 from http://www.hyperhistory.netapwh/bios/blesther_plmw.html

Nygren, M. (1999). On the road to spiritual maturity. Electronic newsletter, $6(1)$. Retrieved May 19, 2009, from www.scribd.com/doc/

Obama, B. H. (February 2008). Town hall meeting with people of Elkhart on Health Insurance. Elkhart, Indiana State.

Obama, B. H. (2009). Explaining principles of economic stimulus. Elkhart, IN: Town Hall.

O'Collins, G. (2007). Jesus: A portrait. Maryknoll, NY: Darton, Longman \& Todd.

Oestergaard, S and Hall, S. In Greenleaf, R. (2001). Servant leadership: A journey into nature of legitimate power and greatness. Mahwah, NJ: Paulist.

Ooms, T. (1981). Teenage pregnancy in family context: Implications for policy, (Ed.), Philadelphia, PA: Temple University.

Ortiz, L. F. (1997). Towards a theology of youth ministry and its praxis in the local church. Doctor of Ministry dissertation, Andrews University, Berrien Springs, MI.

Pamela, K. (1998). Create in me a youth ministry: New directions for youth ministry. Colorado: Group.

Paterson, M. (1975). The bar mitzvah book. London: Windham \& Howard.

Paulsen, J. (September 2007). Let us talk: Interaction with South Korean youth Hope Channel Media.

Pearce, C. L. and Conger, J. A. (2003). Shared leadership: Refraining the how and whys of leadership. Thousand oaks: Sage.

President Mills (April, 26, 2009) Lauds Asantehene for exemplary leadership. GNA News. Retrieved June 12, 2008, from www.Ghanaweb.com

Pyatt, B. G. (1982). Youth empowerment in the church: A handbook for youth ministry. New York: United Church.

Ratcliff, D. \& Davis J. (1991). Handbook of youth ministry. Birmingham, Alabama: Religious Education. 4(2), 56.

Rediger, G. (1999). Fit to be a pastor: a call to physical, mental, and spiritual fitness. Louisville, KY: Westminister John Knox. 
Research Report Summary: (2007) Social Networking Sites and Teens put out by the Pew and American life Project, Retrieved on September 12, 2009, from http://www.pewinternet.org/pdfs/PIP_SNS_Dat_Memo_Jan_2007.pdf

Rice, W. (1998). Junior high ministry: A guide to early adolescent for youth workers. Grand Rapids, MI: Zondervan.

Richards, L. O. (1981). The complete book of youth ministry. Chicago, IL: Moody.

Robbins, D. (1990). The ministry of nature: How to build real-life faith into kids. Grand Rapids, MI: Zondervan.

Robbins, D. (2004). Way to Youth Ministry: Making, case studies, resources, to begin the journey, companion guide. Grand Rapids, MI: Zondervan.

Roehkepartin, J. (1990). Youth ministry: Its impact on church growth. Loveland: Group.

Roger, C.R. (1995). Way of being. Boston, MA: Houghton Mifflin Harcourt.

Root, A. (2004). Youth ministry as an integrative theological task. Plenary address at the Association of Youth Ministry Educators Conference, Denver, Colorado.

Rost, J.C. (1991). Leadership for the twenty-first century: How do knowledge workers show leadership without being in a managerial position? Westport, CT: Preager Search Institute.

Sampaio, A. (Oct. /Dec. 2008). The art of speech: Overcoming the fear of public speaking. Elder's Digest, 14(4), 7.

Santrock, J. W. (1986). Life-Span development ( $7^{\text {th }}$ ed.). New York: McGraw-Hill.

Schneider, T. (2000). Berit Olam: Studies in Hebrew narrative \& poetry. Collegeville, MN: The Liturgical.

Schultz, T. \& Schultz, J. (1987). Involving youth in the ministry: A new way to help kids take responsibility. Loveland, CO: Group.

Scottie, M., Posterski, C., Stonehouse, C., \& Cannell, L. (2005). Children matter: Celebrating their place in the church, and community. Grand Rapids, MI: Wm Eerdmans.

Search Institute (1984). An exploratory study of the interests and needs of CommunityBased and Faith-Based youth workers. Michigan State University, East Lansing.

Senter, M. K. (1987). Axioms of youth ministry. In Benton, W. S. (Ed.). (1987). The complete book of youth ministry. Chicago, IL: Moody. 
Seventh-day Adventist church manual, $16^{\text {th }}$ ed. (2000). Business Meetings. Hagerstown, Maryland: Review and Herald.

Shedd, W. G. T. (1888) Dogmatic theology, vol. 3.Cambridege, MA: Scribner In Brian Schwertley (n. d.). The Incarnation of Christ. Retrieved on November 14, 2009, from http://www.entrewaves.com/view/reformedonline/Incarnation.htm

Shultz, T., \& Schultz, J. (1983). Involving youth in youth ministry. Loveland, CO: Group.

Smith, C, \& Denton, M. (2005). The faith of the next generation. Seminar at Seattle Pacific University day of common learning and church leaders forum. Seattle, Washington.

Smith, D. P. (1996). Empowering ministry. Institute for youth ministry: Ways to grow in effectiveness. Louisville, Kentucky: John Knox.

Spader, J. \& Clem, H. (2007). Leading the youth. In J. C. McDowell, (2000). Youth ministry handbook. Nashville, TN: Word.

Spurgeon C. H. (1997). Spurgeon Commentary on the great chapters of the Bible: Grand Rapids, MI: Hodder \& Stoughton.

Stevens, D. (1985). Called to care: Youth ministry for the church. Grand Rapids, MI: Zondervan.

Stodgill, R. M., Bass, B. M. (1990). Bass \& Stodgill's handbook of leadership: theory, research, and managerial applications. New York, NY: Simon and Schuster.

Stone, J. D. (Ed.). (1980). The complete youth ministries handbook, vol.1. Nashville, TN: Abingdon.

Stortz, R. (2004). Daniel: The triumph of God's kingdom. Wheaton, IL: Crossway.

Stott, J. (1992). The contemporary Christian. Leicester: InterVarsity.

Strommen, M. P. (1997). The innovative in the Church: Seven steps to positive change in your congregation. Lincoln, NE: Augsburg Books.

Strommen M. P. (2001). Evaluating priority outcomes: Youth response and witness. In D. Rahn D (Ed.), Youth ministry that transforms. Grand Rapids, MI: Zondervan.

Strommen M. P. and Hardel, R. A. (2000). Passing on the faith: A radical new model for youth and family ministry. Winona, MN: St Mary Press. 
Strommen, M. P., Jones, K. E., and Rahn, D. (2001). Youth ministry that transforms: A comparative analysis and effectiveness of today's youth workers. Grand Rapids, MI: Zondervan.

Tenney, M. C. \& Barabas, S., (1976). The pictorial encyclopedia of the Bible v. 4-M-P. Grand Rapids, MI: Zondervan.

Thevenin, M. C. (2001). Strengthening a junior high youth ministry in the context of Morija Seventh-dayAdventist Church. Ann Arbor, MI: University Microfilms.

Titus, C. H. (1950). The process of leadership. Dubuque, Iowa: William C. Brown.

Troeltsch, E. (1932). The social teaching of the Christian churches. London: Allen and Union.

Unger, M. F., Harrison, R. K., Vos, H. F., and Barber, C. (1988). The new Unger's Bible dictionary. Chicago: Moody.

Van Hasselt, V. B., \& Hersen, M. (1987). Handbook of adolescent psychopathology. New York, N.Y: Pergamon.

Vine, W.E. (1985). Vine's expository dictionary of Bible words. Nashville, TN: Old Tappan, NJ: Nelson.

Wallace, J. M. jr., \& Foreman, T. A. (1998). Religion's role in promoting health and reducing risk among American youth. Health Education and Behavior, 25(6), 721741.

Walsh, F. (1998). Strengthening family resilience. New York, NY: Guilford.

Ward P. (1998). Christian Religion care, relational youth. Oxford, England: Lynx Communication.

Ward, P. (1999). God at the mall. Peabody, MA: Hendrickson.

Webster, N. (1937). Webster's collegiate dictionary. Kansas City: G. \& C. Merriam.

Weems Jr., J.H. (1999). Leadership in the Wesleyan spirit. Nashville, TN: Abingdon.

White, E. G. (1890). What is preaching and what is not. Adventist Review and Herald. par., 6.

White, E.G. (1893). Youth in church work. General Conference Bulletin. 5(2), 24.

White, E. G. (1898). Desire of ages. Mountain View, CA: Pacific. 
White, E. G. (1905). Ministry of healing. Mountain View, CA: Pacific.

White, E. G. (1911). The Youth's Instructor, November 21.

White, E. G. (1925). Christian service. Takoma, WA: General Conference of Seventhday Adventists.

White, E. G. (1930). Messages to the young people. Nashville, TN: Southern.

White, E. G. (1942). Ministry of healing. Mountain View: Pacific.

White, E. G. (1943). Counsels to parents, teachers, and students. Boise, ID: Pacific.

White, E. G. (1955). Patriarch and Prophets. Mountain View, CA: Pacific.

White, E. G. (1958a). The faith I live by. Mountain View, CA: Review and Herald.

White, E. G. (1958b). Selected Messages vol. 1. Washington, DC: Review and Herald.

White, E. G. (1983). Evangelism. Mountain View: Review and Herald.

White, E. G. (1985). Reflecting Christ. Washington, DC: Review Herald.

Wilhoit, Jim. (1991). Christian education and search for meaning. 2nd ed. Grand Rapids, MI: Baker.

Wilson, W. (1987). New Wilson's word studies. Grand Rapids, MI: Kregel.

Wong, D. (1997). The responsibilities of Christian leaders: Youth Ministry Ascent. First Retrieved November12, 2008 from www.edletter.org/past/issues/2001

Yaconelli, M. (1999). Youth Ministry. A contemplative approach. Retrieved July 16, 2009, from http://findarticles.com/mi_m1058/is_13_116/ai_54588515/pg_2?

Yaconelli, M. (2008). Presentation on contemporary youth in Christ, Shift, Session2. San Francisco, CA: Retrieved August 5, 2009, from www.youthspecialities.com

Yoder, B. (2009). The role of biblical lament in adolescents. The Journal of Youth Ministry, 7 (2), 51. 
VITA

\section{Personal}

Name Kofi Opoku Acheampong

Hometown Offinso, Ashanti Region of Ghana

Spouse Agnes Opoku Acheampong

Children Japhet and Elsie O. Acheampong

\section{Education}

Bachelor of Theology $1989-1991$ Valley View University, Accra, Ghana 1992 - 1996 Babcock University, Remo - Illishan, Nigeria

Master of Divinity

$2003-2004$ La Sierra University, Riverside, CA. 2004-2006 Andrews University, Berrien Springs, MI.

Doctor of Ministry

2006 - 2009 Andrews University, Berrien Springs, MI.

\section{Employment}

Literature Evangelist

1977 - 1982 SDA Church, Takoradi, Ghana 1982 - 1986 South Suntreso SDA, Kumasi, Ghana

Pastoral Work

1991 -1992 Associate District Pastor, Sefwi Essam, Ghana

1996 - 1998 District Pastor, Anwiankwanta, Asante Bekwai, Ghana

1998 - 2000 District Pastor, Sefwi Bekwai, Ghana

2000 - 2002 District Pastor, Bantama, Ghana

2002-2003 Publishing Director, CGC of Seventhday Adventists, Ghana. 